\title{
FLÁVIA MATARAZZO
}

\section{DIVERSIDADE E ANÁLISE QUANTITATIVA DE MICRORGANISMOS DO DOMÍNIO ARCHAEA EM AMOSTRAS DE BIOFILME SUBGENGIVAL DE INDIVÍDUOS COM PERIODONTITE AGRESSIVA E SAÚDE PERIODONTAL}

Tese apresentada ao Programa de PósGraduação em Microbiologia do Instituto de Ciências Biomédicas da Universidade de São Paulo, para obtenção do Título de Doutor em Ciências. 


\section{FLÁVIA MATARAZZO}

\section{DIVERSIDADE E ANÁLISE QUANTITATIVA DE MICRORGANISMOS DO DOMÍNIO ARCHAEA EM AMOSTRAS DE BIOFILME SUBGENGIVAL DE INDIVÍDUOS COM PERIODONTITE AGRESSIVA E SAÚDE PERIODONTAL}

Tese apresentada ao Programa de PósGraduação em Microbiologia do Instituto de Ciências Biomédicas da Universidade de São Paulo, para obtenção do Título de Doutor em Ciências.

Área de Concentração: Microbiologia

Orientadora:

Profa. Dra. Marcia Pinto Alves Mayer. 
DADOS DE CATALOGAÇÃO NA PUBLICAÇÃO (CIP)

Serviço de Biblioteca e Informação Biomédica do

Instituto de Ciências Biomédicas da Universidade de São Paulo

(C) reprodução total

Matarazzo, Flávia.

Diversidade e análise quantitativa de microrganismos do domínio Archaea em amostras de biofilme subgengival de indivíduos com periodontite agressiva e saúde periodontal. / Flávia Matarazzo. -São Paulo, 2010.

Orientador: Márcia Pinto Alves Mayer.

Tese (Doutorado) - Universidade de São Paulo. Instituto de Ciências Biomédicas. Departamento de Microbiologia. Área de concentração: Microbiologia. Linha de pesquisa: Microbiologia Oral.

Versão do título para o inglês: Diversity and quantitative analysis of microorganisms of Archaea domain in biofilm subgingival samples from aggressive periodontitis and periodontally healthy subjects.

$\begin{array}{llll}\text { Descritores: } 1 . \text { Archaea } & \text { 2. } 16 S \text { rRNA } & \text { 3. Biofilme subgengival } 4 .\end{array}$ Periodontite agressiva 5. Saúde periodontal I. Mayer, Márcia Pinto Alves II. Universidade de São Paulo. Instituto de Ciências Biomédicas. Programa de Pós-Graduação em Microbiologia III. Título. 
Candidato(a):

Flávia Matarazzo.

Título da Tese:

Diversidade e análise quantitativa de microorganismos do domínio Archaea em amostras de biofilme subgengival de indivíduos com periodontite agressiva e saúde periodontal.

Orientador(a): Marcia Pinto Alves Mayer.

A Comissão Julgadora dos trabalhos de Defesa da Tese de Doutorado, em sessão pública realizada a $. / . . . \ldots \ldots \ldots . . . . .$, considerou

\section{( ) Aprovado(a) \\ ( ) Reprovado(a)}

\begin{tabular}{|c|c|}
\hline Examinador(a): & $\begin{array}{l}\text { Assinatura: } \\
\text { Nome: ........ } \\
\text { Instituição: }\end{array}$ \\
\hline Examinador(a): & $\begin{array}{l}\text { Assinatura: } \\
\text { Nome: ........ } \\
\text { Instituição: }\end{array}$ \\
\hline Examinador(a): & $\begin{array}{l}\text { Assinatura: } \\
\text { Nome: ........ } \\
\text { Instituição: }\end{array}$ \\
\hline Examinador(a): & $\begin{array}{l}\text { Assinatura: } \\
\text { Nome: ........ } \\
\text { Instituição: }\end{array}$ \\
\hline Presidente: & $\begin{array}{l}\text { Assinatura: } \\
\text { Nome: ........ } \\
\text { Instituição: }\end{array}$ \\
\hline
\end{tabular}


São Paulo, 14 de novembro de 2007.

\section{PARECER 814/CEP}

Prezada Senhora

Atendendo sua solicitação, a Comissão de Ética em Pesquisas com Seres Humanos do ICB, em șua $80^{\circ}$, reunião realizada em 13.11.07, analisou o projeto de sua responsabilidade intitulado: "Diversidade e quantificação de organismos do dominio Archaea em amostras de biofilme subgengival de indivíduos com periodontite agressiva e saúde periodontal".

Informo a V.Sa. que, após análise e discussão o referido projeto foi aprovado por esta Comissão.

Lembramos que cabe ao pesquisador elaborar e apresentar a este Comitê, relatórios anuais (parciais ou final), de acordo com a resolução 196/06 do Conselho Nacional da Saúde, item IX.2 letra c.

O primeiro relatório deverá ser encaminhado à Secretaria deste CEP em 13 de novembro de 2008.

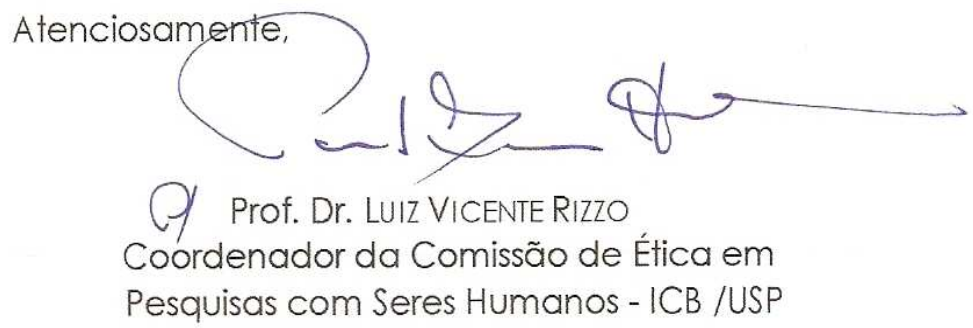

IIma. Sra.

FLÁVIA MATARAZZO

Departamento de Microbiologia

Instituto de Ciências Biomédicas -USP 
Dedico este trabalho

Aos meus pais, Armando e Maura, em quem busco forças para lutar.

Ao meu marido, Guilherme, que superou os períodos em que eu não pude estar perto. 


\section{AGRADECIMENTOS}

A Deus, Pai, Filho e Espírito Santo, cuja luz não se apaga.

A Marcia Mayer, minha orientadora, pelo respeito e paciência em me orientar. Os caminhos profissionais foram se abrindo durante o Doutorado, e mesmo preocupada com a conclusão dos experimentos, nunca deixou de me apoiar nas minhas decisões.

A Adriana Ribeiro, minha eterna amiga, com quem venci todas as dificuldades metodológicas deste trabalho e em quem confio os desafios da vida extra-laboratorial.

A Josely Umeda, que me acolheu incondicionalmente, no laboratório e no conforto de sua casa durante uma boa parte do Doutorado.

A Silvia Teixeira, também pelo acolhimento e por ser tão prestativa, prática e atenciosa neste período importante da minha vida.

Ao Marcelo de Faveri, que sempre me abriu os caminhos da Pós-Graduação, tornando o contato inicial com os meus orientadores muito mais prazeroso. Também por ter cedido as amostras clínicas analisadas neste trabalho.

Aos amigos do Laboratório de Microbiologia Oral, Ellen, Dione, Cristina, Éricka, Priscila, Talita, Ana Carla, Felipe, Daniela, Lucas, Mayke, pela convivência tão agradável do dia a dia.

Ao João e ao Léo, técnicos do laboratório, pela amizade e por facilitarem a realização dos experimentos e confecção da tese.

Ao Laboratório de Microbiologia Ambiental, representado pela Profa. Dra. Vivian Pelizzari, que cedeu a amostra que serviu de controle positivo para Archaea e 
especialmente e à Ana Carolina, pós-graduanda deste laboratório, com quem sempre esclarecia dúvidas sobre diversidade microbiana.

Ao Laboratório de Genética, representado pela Profa. Dra. Elizabete, que disponibilizou o equipamento para análise por PCR quantitativo. 
Porque parece que na hora não vou agüentar, se eu sempre tive força, e nunca parei de lutar? Trecho da Música "Pensa em mim” de Bernardo Faria/Conrado D'Avila 
ESTE TRABALHO FOI FINANCIADO PELA FUNDAÇÃO DE AMPARO À PESQUISA DO ESTADO DE SÃO PAULO (FAPESP)

PROCESSOS 2006/52890-6 E 2007/52509-6 


\section{RESUMO*}

MATARAZZO, F. Diversidade e análise quantitativa de microrganismos do domínio Archaea em amostras de biofilme subgengival de indivíduos com periodontite agressiva e saúde periodontal. $201085 \mathrm{f}$. Tese (Doutorado em Microbiologia) - Instituto de Ciências Biomédicas, Universidade de São Paulo, São Paulo, 2010.*

Membros do domínio Archaea podem ser detectados na microbiota de superfícies mucosas do homem e de animais, mas sua associação com patogenias ainda não foi estabelecida. $\mathrm{O}$ objetivo deste estudo foi determinar a prevalência, a diversidade, os níveis e proporções de microrganismos do domínio Archaea em amostras de biofilme subgengival de indivíduos com periodontite agressiva e saúde periodontal. Trinta indivíduos com periodontite agressiva (PA) e 30 com saúde periodontal (SP) foram selecionados. A detecção de Archaea foi realizada por PCR em 9 sítios subgengivais por indivíduo usando iniciadores domínio-específicos. A diversidade de Archaea no biofilme subgengival foi verificada em amostras positivas para este domínio obtidas de 10 indivíduos do grupo PA e 10 indivíduos do grupo SP. Bibliotecas genômicas $16 S$ rRNA de Archaea foram construídas para cada amostra e os filotipos identificados pela comparação das sequências obtidas com o banco de genes. Os níveis e proporções de Archaea em relação ao total de procariontes foram analizados por PCR quantitativo (qPCR) em amostras de 4 sítios/indivíduo do grupo PA e em 2 sítios/indivíduo do grupo SP. Um total de 540 amostras subgengivais foi analisado para a presença de Archaea. Este domínio foi detectado em 18 indivíduos do grupo PA $(60 \%)$ e em 20 indivíduos do grupo SP $(63,3 \%)$. Archaea foi detectado em $41(15,2 \%)$ e 42 $(15,6 \%)$ sítios do grupo PA e SP, respectivamente. Não houve diferença na prevalência deste domínio entre indivíduos do grupo PA e SP (Qui-quadrado, $\mathrm{p}>0,05)$. O número de clones $16 S$ rRNA disponíveis para a identificação por amostra variou de 33 a 47 no grupo $\mathrm{PA}$, e de 15 a 23 no grupo SP, com uma média de $42,8 \pm 3,9$ e $20,1 \pm 2,2$, respectivamente. A análise de 629 seqüências permitiu a identificação de 1 a 3 filotipos do domínio Archaea por amostra, no grupo PA e SP. Methanobrevibacter oralis foi detectada em todas as amostras positivas, sendo a única espécie deste domínio detectada em 5 indivíduos do grupo PA, e em 3 indivíduos do grupo SP. Methanobacterium curvum foi identificado em 3/10 amostras do grupo PA e em 6/10 amostras do grupo SP, enquanto Methanosarcina mazeii foi detectada em 4/10 amostras em cada grupo. A análise por qPCR foi realizada em amostras obtidas de 103 sítios de 28 indivíduos do grupo PA e de 60 sítios de 30 indivíduos do grupo SP. Archaea foi detectado em 27/28 indivíduos e em $68 \%$ dos sítios estudados no grupo PA e em $26 / 30$ indivíduos e $58,3 \%$ do total de sítios do grupo SP. O nível médio de cópias do gene $16 S$ rRNA de Archaea e Bacteria foi menor no grupo SP que no grupo PA (Mann Whitney, $\mathrm{p}<0,05$ ). Não houve diferença estatisticamente significante na quantidade de Archaea em relação à profundidade de sondagem nos sítios do grupo PA $(\mathrm{p}>0,05)$. Além disso, a proporção de Archaea em relação ao total de organismos procariontes (Archaea + Bacteria) foi de $0,02 \%$ e $0,08 \%$ no grupo SP e PA $(\mathrm{p}<0,05)$, respectivamente. Archaea são frequentemente encontrados no biofilme subgengival de indivíduos com periodontite agressiva e saúde periodontal. Methanobrevibacter oralis é a espécie do domínio Archaea mais prevalente, podendo ser considerada um microrganismo residente

da cavidade bucal. A alteração ecológica na microbiota de indivíduos com periodontite agressiva inclui o aumento dos níveis e proporções do domínio Archaea. 
Palavras-chaves: Archaea. $16 S \mathrm{rRNA}$. Biofilme subgengival. Periodontite agressiva. Saúde periodontal. 


\section{ABSTRACT}

MATARAZZO, F. Diversity and quantitative analysis of microorganisms of Archaea domain in biofilm subgingival samples from aggressive periodontitis and periodontally healthy subjects. 2010. 85 p. PhD Thesis (Microbiology) - Instituto de Ciências Biomédicas, Universidade de São Paulo, São Paulo, 2010.

Membrers of Archaea domain may be detected in the microbiota of mucous surfaces of human and animals, but their association with diesase have not been yet stablished Some studies have suggested that Archaea domain may be indirectly associated with pathogenesis of periodontitis, since they are found restrict to subgingival sites with severe periodontal destruction. The aim of this study was to determine the prevalence, diversity, levels and proportions of microorganisms of Archaea domain in subgingival biofilm of aggressive periodontitis and periodontally healthy subjects. Thirty generalized aggressive periodontitis (GAgP) and 30 periodontally healthy $(\mathrm{PH})$ subjects were selected. Archaea detection was performed by PCR using domain-specific primers in 9 subgingival samples taken from each subject. Archaea diversity was determined by evaluating a single positive sample per subject, randomly selected from $10 \mathrm{GAgP}$ and $10 \mathrm{PH}$ subjects. Archaeal $16 \mathrm{~S}$ $r R N A$ gene library were constructed to each sample and the identity of phylotypes were determined for the comparison of unrecognized sequences with gene database. The levels and proportions of Archaea in relation to total microbial load were analysed by quantitative PCR (qPCR) in 4 sites per GAgP subject and 2 sites per PH subject. A total of 540 subgingival samples were analysed to Archaea presence. This domain were detected in 18 GAgP (60\%) and in $19 \mathrm{PH}(63.3 \%)$ subjects. Forty-one (15.2\%) and 42 (15.6\%) samples were positive for this domain in $\mathrm{GAgP}$ and $\mathrm{PH}$ subjects, respectively. There was not difference in prevalence of this domain between subjects from GAgP and $\mathrm{PH}$ groups, as well as there was not difference in prevalence between sites with different probing depthsin GAgP group. Thenumber of $16 S r R N A$ clones available to identification per sample varies from 33 to 47 in GAgP group, and from 15 to 23 in $\mathrm{PH}$ group, with a mean of $42.8 \pm 3.9 \mathrm{e}$ $20.2 \pm 2.2$, respectively. The analysis of 629 sequencies permits an identification of 1 to 3 phylotypes of Archaea domain per sample. Methanobrevibacter oralis was detected in all archaeal positive samples, being the single detected specie of this domain in 5 subjects from GAgP group, and in 3 subjects from $\mathrm{PH}$ group. Methanobacterium curvum/congolense was detected in 3/10 GAgP and 6/10 PH samples, whereas Methanosarcina mazeii was detected in 4/10 samples from both groups. Archaea analysis by qPCR was carried out in 103 sites and $28 \mathrm{GAgP}$ subjects and in 60 sites and $30 \mathrm{PH}$ individuals. Archaea has been detected in $27 / 28$ subjects and in $68 \%$ of studied sites in GAgP group and in 26/30 subjects and 58,3\% of total analysed sites in PH group. Archaeal and bacterial $16 S r R N A$ mean levels were lower in PH group than in GAgP group (Mann Whitney, $\mathrm{p}<0.05)$. There was no statistic significance of difference in the levels of Archaea in regard to probing depth categories in GAgP group ( $\mathrm{p}>0.05)$. Moreover, the proportion of Archaea in relation to total microbial load (Archaea + Bacteria) was $0.02 \%$ and $0.08 \%$ in $\mathrm{PH}$ and GAgP group $(\mathrm{p}<0.05)$, respectively. These data suggest that Archaea is commonly found in the subgingival biofilm of humans, and that $M$. oralis may be considered a member of the resident microbiota of subgingival sites. The ecological shift in the microbiota of aggressive periodontitis subjects includes the increase of levels and proportions of Archaea domain. 
Key-words: Archaea. $16 S \mathrm{rRNA}$. Subgingival biofilm. Aggressive periodontitis. Periodontally healthy. 


\section{LISTA DE ILUSTRAÇÕES}

Figura 1. Fotografia do gel de agarose $(1,5 \%)$ corado com brometo de etídio em tampão TAE (1X) onde foram submetidos à eletroforese os produtos das reações de amplificação utilizando os iniciadores listados na Tabela 1. (K) par de iniciadores descrito por KULIK et al. (2001) e (L) par de iniciadores descrito por LEPP et al. (2004); (A) DNA molde de um sítio profundo e (B) de um sítio raso de um mesmo indivíduo com periodontite agressiva. (+) Controle positivo e (-) Controle negativo. 100 bp: Peso Molecular 100 bp DNA Ladder (Fermentas)

Figura 2. Árvore filogenética construída a partir da seqüência de 500-600 pb do gene $16 S$ rRNA das espécies detectadas a partir de bibliotecas genômicas obtidas usando como DNA molde uma amostra de biofilme subgengival de um sítio profundo (amostra A) de um indivíduo com periodontite agressiva, utilizando 2 pares de iniciadores diferentes para Archaea descritos por Kulik et al. (2001) e Lepp et al. (2004). A distância filogenética dos clones seqüenciados é dada em porcentagem de nucleotídeos substituídos após alinhamento e aproximação pelo método de Jukes e Cantor (1969), usando o programa Bionumerics 50

Figura 3. Árvore filogenética construída a partir da seqüência de $500-600$ pb do gene $16 S$ rRNA das espécies detectadas a partir de bibliotecas genômicas obtidas usando como DNA molde uma amostra de biofilme subgengival de um sítio raso (amostra B) de um indivíduo com periodontite agressiva, utilizando 2 pares de iniciadores diferentes para Archaea descritos por Kulik et al. (2001) e Lepp et al. (2004). A distância filogenética dos clones seqüenciados é dada em porcentagem de nucleotídeos substituídos após alinhamento e aproximação pelo método de Jukes e Cantor (1969), usando o programa Bionumerics.. 51

Figura 4. Distribuição e percentual de sítios com Archaea detectável nas diferentes categorias de profundidade de sondagem (PS) analisadas no grupo com periodontite 
agressiva. Diferença estatisticamente significante entre as categorias de PS (Teste KruskalWallis, $\mathrm{p}>0,05)$.

Figura 5. Distribuição de sítios positivos e negativos para Archaea no grupo com periodontite agressiva, em sítios com profundidade de sondagem (PS) rasa (PS $\leq 3 \mathrm{~mm}$ ) e $\mathrm{PS} \geq 4 \mathrm{~mm}$. Diferença estatisticamente significante entre as categorias de PS (Teste Quiquadrado, $* p<0,05)$ 53

Figura 6. Árvore filogenética baseada nas seqüências do gene $16 S \operatorname{RNA}$ (GENBANK) das espécies de Archaea metanogênicas identificadas em amostras de biofilme subgengival obtidas de 10 indivíduos com periodontite agressiva (PA) e de 10 indivíduos com saúde periodontal (SP). A distância filogenética dos clones seqüenciados é dada em porcentagem de nucleotídeos substituídos após alinhamento e aproximação pelo método de Jukes e Cantor (1969), usando o programa Bionumerics 54

Figura 7. Porcentagem do número de clones identificados como Methanobrevibacter oralis, Methanobacterium curvum/congolense e Methanosarcina mazeii em amostras de biofilme subgengival de indivíduos com saúde periodontal (A) e periodontite agressiva generalizada $(\mathrm{P})$. 55

Figura 8. Curvas de rarefação da diversidade de Archaea em amostras obtidas de 10 indivíduos com saúde periodontal (SP, A) e com periodontite agressiva generalizada (PA,

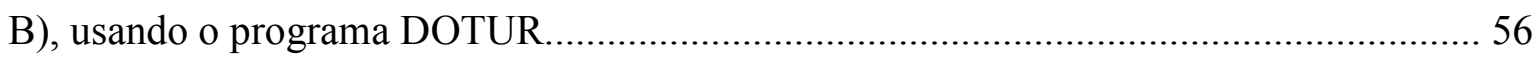

Figura 9. Distribuição e percentual de sítios com Archaea detectável em relação ao total de sítios analisados no grupo com saúde periodontal (SP) e nas categorias de sítios rasos (PS $\leq 3 \mathrm{~mm}$ ) e profundos ( $\mathrm{PS} \geq 5 \mathrm{~mm}$ ) no grupo com periodontite agressiva generalizada. Não houve diferença estatisticamente significante entre as categorias analisadas (Teste KruskalWallis, $p>0,05$ ). 58 
Figura 10. Média do número de cópias do gene $16 S r R N A$ de Archaea (x10 4 EMM, A) e média do número de cópias de cópias do gene $16 S$ rRNA de Bacteria (x10 $\left.{ }^{7} \pm \mathrm{EMM}, \mathrm{B}\right) \mathrm{em}$ amostras obtidas de indivíduos com saúde periodontal e periodontite agressiva. Teste $U$

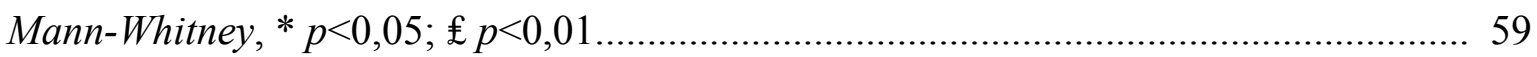

Figura 11. Média do número de cópias do gene $16 S$ rRNA de Archaea $\left(\times 10^{4} \pm \mathrm{EMM}\right)$ e Bacteria $\left(\times 10^{7} \pm \mathrm{EMM}\right)$ nos sítios rasos de indivíduos do grupo SP e nos sítios rasos e profundos dos indivíduos do grupo PA. Teste $U$ Mann-Withney, *

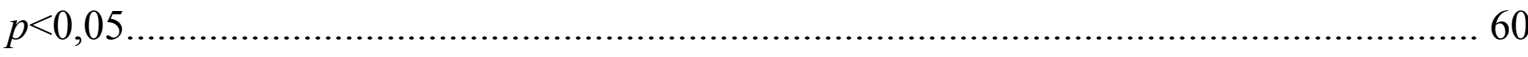

Figura 12. Média de proporção de microrganismos do domínio Archaea em relação ao total de procariontes (Archaea + Bacteria) em amostras de indivíduos com saúde periodontal e periodontite agressiva generalizada. O grupo com periodontite agressiva generalizada foi subdividido por categoria de profundidade de sondagem (PS) em sítios

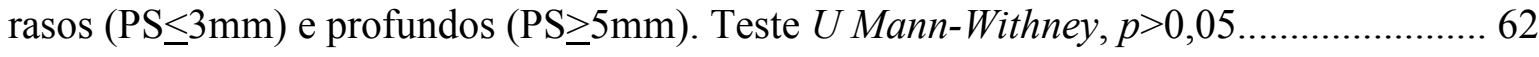




\section{LISTA DE TABELAS}

Tabela 1- Iniciadores analisados e condições para detecção do domínio Archaea............ 39

Tabela 2- Média ( \pm DP) dos parâmetros demográficos e clínicos para os indivíduos com saúde periodontal e periodontite agressiva 48

Tabela 3- Prevalência do domínio Archaea em amostras obtidas de indivíduos com saúde periodontal e periodontite agressiva por PCR convencional 52

Tabela 4- Prevalência do domínio Archaea em amostras obtidas de indivíduos com saúde periodontal e periodontite agressiva por PCR em tempo real 57

Tabela 5- Proporção de Archaea e Bacteria em relação ao total de procariontes. 


\section{LISTA DE ANEXOS}

ANEXO A- Termo de Consentimento Livre e Esclarecido ............................................ 82 


\section{LISTA DE ABREVIATURAS}

DNA - Ácido dexoxiribonucléico

$\boldsymbol{r} \boldsymbol{R} \boldsymbol{N} \boldsymbol{A}$ - RNA ribossômico

SSU $\boldsymbol{r} \boldsymbol{R} \boldsymbol{N} \boldsymbol{A}$ - Subunidade menor do RNA ribossômico

pH - Potencial hidrogênco

$\mathbf{H}_{\mathbf{2}}$ - Hidrogênio

$\mathrm{CO}_{2}$ - Dióxido de Carbono

PCR - Reação em cadeia da polimerase

Ig - Imunoglobulina

SP - Saúde periodontal

PA - Periodontite agressiva generalizada

mm - Milímetros

IPV - Índice de placa visível

ISG - Sangramento gengival

PS - Profundidade de sondagem

NCI - Nível clínico de inserção

SS - Sangramento à sondagem

mL- Mililitros

$\boldsymbol{\mu} \mathbf{L}$ - Microlitro

TE - Tris EDTA

HCL - Ácido Clorídrico

EDTA - Ácido etilenodiamino tetra-acético

mM- Milimolar

$\boldsymbol{\mu g}$ - Micrograma

h- Horas

min - Minuto

pb - Pares de base

$\mathbf{M g C L}_{2}-$ Cloreto de Magnésio

dNTP- Desoribonucleotídeo trifosfato

pmol- Picomol

U- Unidades

s - Segundo

TAE - Tris acetato EDTA

mg - miligrama

$\mathbf{N a C l}$ - Cloreto de sódio

KCL- Cloreto de potássio

rpm - Rotações por minuto

LB - Luria Bertani

g - Grama

L- Litro

$\boldsymbol{\mu M}$ - Micromolar

OTU- Unidade taxonômica operacional

A- Absorbância

$\boldsymbol{\eta} \mathbf{M}$ - Nanomolar

$\boldsymbol{\eta} \mathbf{M}$ - Nanometro 


\section{SUMÁRIO}

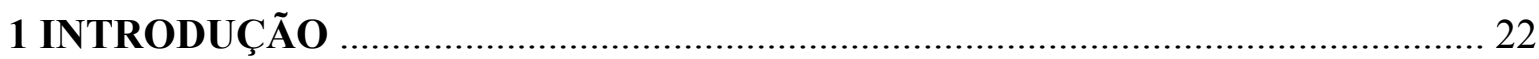

1.1 ETIOLOGIA DA PERIODONTITE AGRESSIVA GENERALIZADA ................... 23

1.2 ECOLOGIA MICROBIANA PERIODONTAL ................................................. 25

1.3 ARCHAEA E O ECOSISTEMA MICROBIANO HUMANO ................................... 27

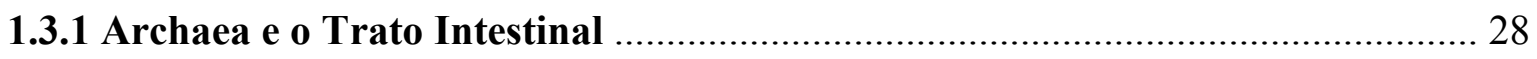

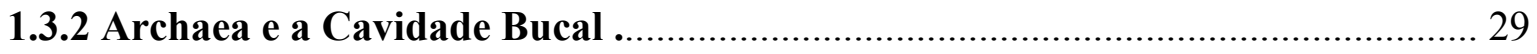

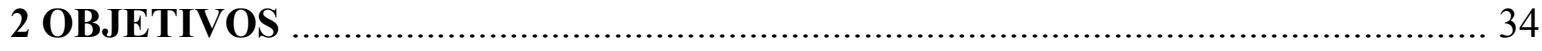

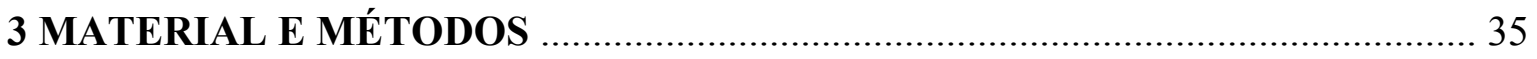

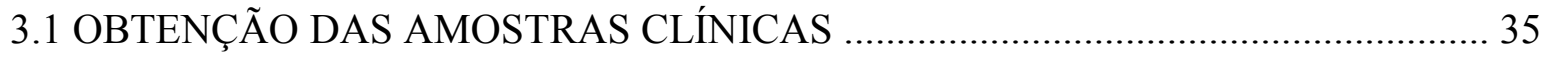

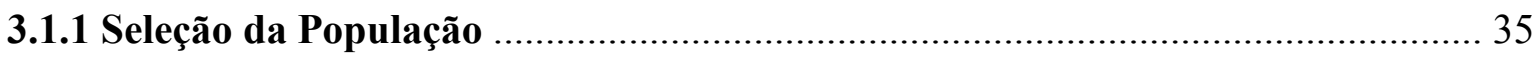

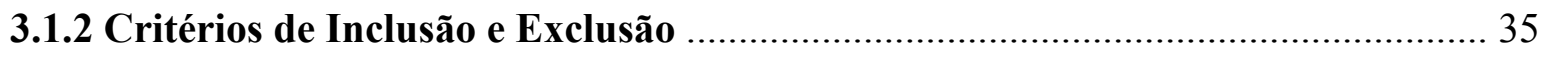

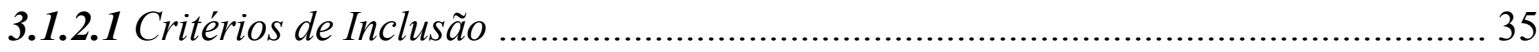

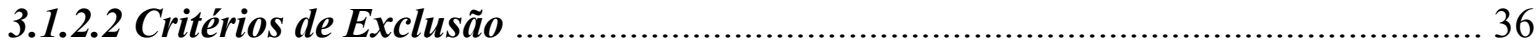

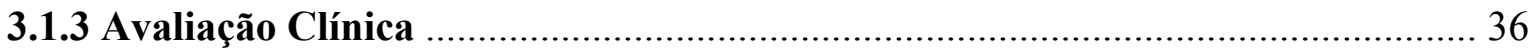

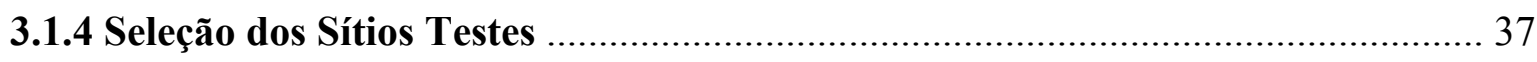

3.1.5 Coleta das Amostras de Biofilme Subgengival ............................................ 37

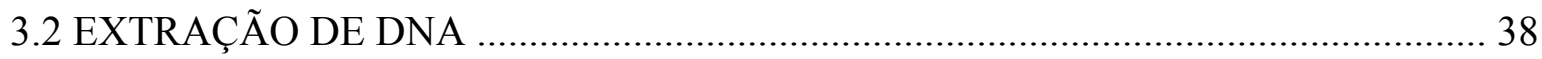

3.3 SELEÇÃO DOS INICIADORES PARA A REAÇÃO DE AMPLIFICAÇÃO DO

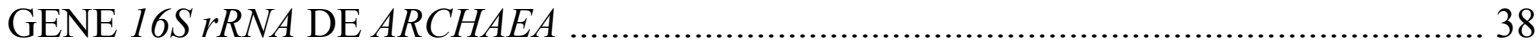

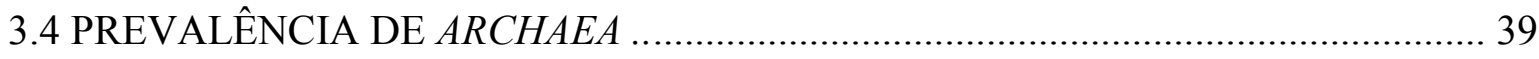

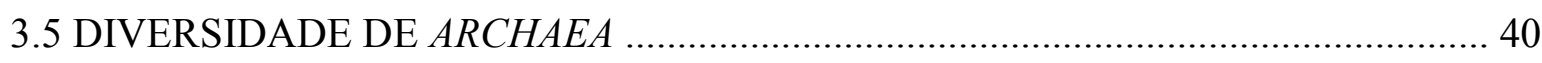

3.5.1 Clonagem e Sequenciamento do Gene $16 S$ rRNA ........................................ 40

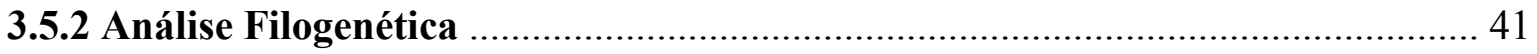

3.5.3 Análise de Rarefação e Índice de Cobertura ................................................... 42

3.6 ANÁLISE QUANTITATIVA DE MICRORGANISMOS DOS DOMÍNIOS ARCHAEA E BACTERIA .............................................................................. 42

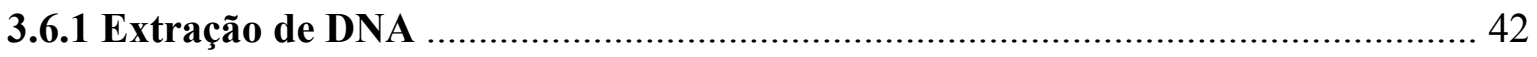

3.6.2 Quantificação do Domínio Archaea ............................................................. 42

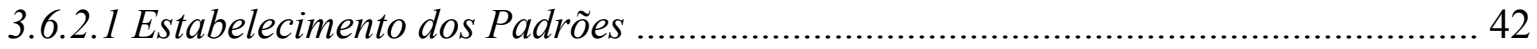

3.6.2.2 Condições Gerais para PCR em Tempo Real .................................................. 43

3.6.2.3 Análise da Curva de Dissociação ....................................................................... 44

3.6.3. Quantificação do Domínio Bacteria ............................................................. 44 


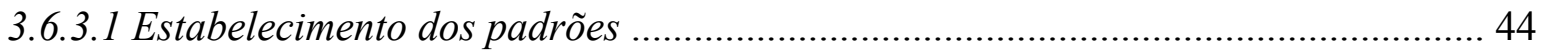

3.6.3.2 Condições gerais para PCR em tempo real ....................................................... 45

3.6.2.3 Análise da curva de dissociação ........................................................................ 46

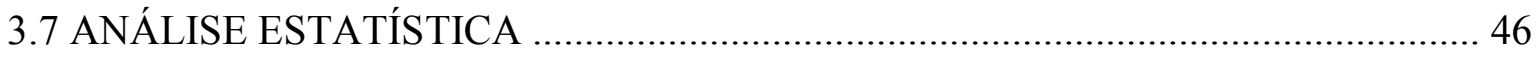

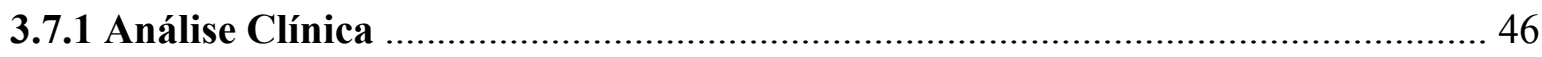

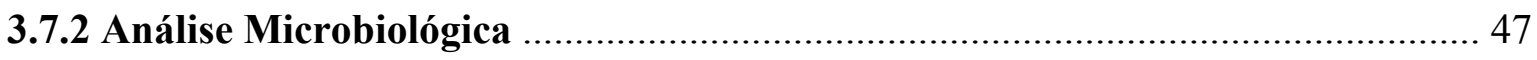

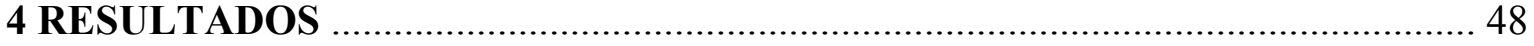

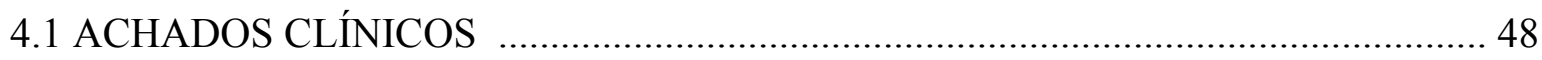

4.2 SELEÇÃO DOS INICIADORES UNIVERSAIS ................................................... 48

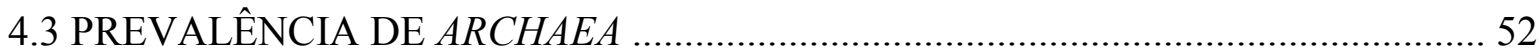

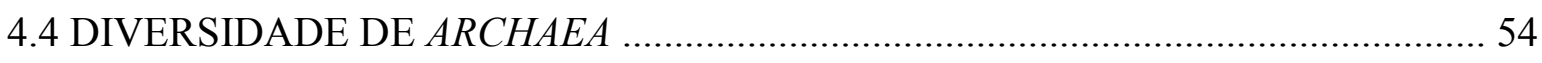

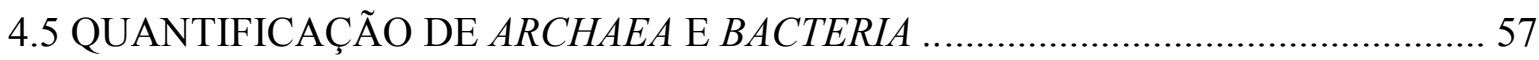

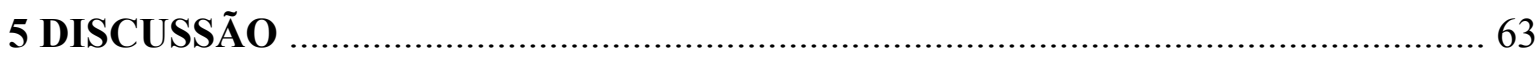

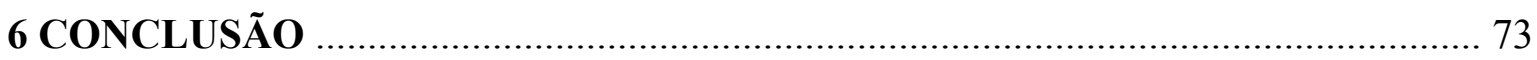

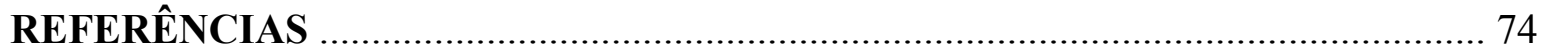




\section{INTRODUÇÃO}

A periodontite agressiva representa um grupo raro de periodontite, de progressão rápida, cujas manisfestações clínicas se iniciam precocemente e existe uma tendência distinta de agregação familiar (ARMITAGE, 1999). O diagnóstico de periodontite agressiva requer a ausência de doença sistêmica e severa destruição do aparato de inserção. Esta manifestação clínica precoce é geralmente interpretada como sendo a expressão de agentes etiológicos altamente virulentos, altos níveis de suscetibilidade do hospedeiro ou a combinação de ambos.

A periodontite agressiva é uma infecção mista, cuja etiologia é mais complexa do que o sugerido no paradigma tradicional de doença envolvendo um único organismo virulento. Isso se deve à organização em biofilme das espécies microbianas que compõem o ambiente subgengival, o que as torna radicalmente diferentes dos fenótipos planctônicos, e cuja interação irá determinar o papel patogênico desta massa microbiana, podendo resultar no início e progressão da doença (PAGE et al., 1997; COSTERTON; STEWART; GREENBERG, 1999; SOCRANSKY; HAFFAJEE, 2005; KOLENBRANDER et al., 2006). As interações microbianas ocorrem em vários níveis incluindo o contato físico, trocas metabólicas, cooperação nutricional, modificação ambiental e a comunicação e regulação gênica mediada por sinalizadores moleculares pequenos (KOLENBRANDER et al., 2006).

Com as técnicas de diagnóstico microbiológico independentes de cultura, muitos microrganismos fastidiosos ou mesmo, ainda não cultivados, estão sendo identificados no ambiente subgengival de bolsas periodontais profundas (SOCRANSKY; HAFFAJEE, 2005; SAKAMOTO et al. 2005; XIMENEZ-FYVIE et al., 2006; FAVERI et al., 2008, FAVERI et al, 2009). Entre os microrganismos recentemente associados à doença periodontal figuram representantes do domínio Archaea (KULIK et al., 2001; LEPP et al., 2004; YAMABE et al., 2008; LI et al., 2009).

Membros do domínio Archaea foram detectados em amostras de biofilme subgengival de indivíduos com periodontite crônica e agressiva, mas sua real associação com as medidas de severidade de doença, como profundidade de sondagem, é conflitante (KULIK et al., 2001; LEPP et al., 2004; YAMABE et al., 2008; LI et al., 2009). A sua associação com a patogenia da doença periodontal foi sugerida por remover produtos finais 
de outros microrganismos, podendo aumentar a atividade microbiana e, assim, direta ou indiretamente, contribuir com a destruição tecidual (KULIK et al., 2001).

\subsection{ETIOLOGIA DA PERIODONTITE AGRESSIVA GENERALIZADA}

Estudos clássicos tentaram identificar os microrganismos envolvidos no processo patológico da periodontite agressiva usando técnicas dependentes de cultura (NEWMAN et al., 1976; SLOTS, 1976; NEWMAN; SOCRANSKY, 1977). Nestes estudos, aproximadamente dois terços dos isolados obtidos de bolsas periodontais profundas, eram compostos por microrganismos Gram-negativos, enquanto, nos sítios controles saudáveis estes representavam somente cerca de um terço dos isolados. Através da utilização de meios seletivos e enriquecidos e baseados em características bioquímicas e morfológicas, os organismos associados com a doença foram identificados como Aggregatibacter actinomycetemcomitans (anteriormente denominado Actinobacillus actinomycetemcomitans), Capnocytophaga sp., Eikenella corrodens, Fusobacterium nucleatum, organismos sacarolíticos semelhantes a Bacteroides atualmente classificados como Prevotella sp. e Porphyromonas sp., e bacilos anaeróbios móveis. No entanto, a complexidade da microbiota subgengival era ainda maior do que previamente determinada, pois uma parte substancial desta não pôde ser identificada devido a limitações metodológicas e esquemas de classificação ambíguos. Desta forma, microorganismos fastidiosos estritamente anaeróbios como Porphyromonas gingivalis e Tannerella forsythia somente foram associados à periodontite agressiva generalizada com o advento de técnicas imunológicas e de sondas de DNA (MULLALLY et al., 2000; HAMLET et al., 2001; KAMMA et al., 2004; XIMENEZ-FYVIE et al., 2006; FAVERI et al., 2008).

Socransky et al. (1994) descreveram a técnica de diagnóstico microbiológico do checkerboard DNA-DNA hybridization que utiliza sondas de DNA para a detecção dos microrganismos que compõem os biofilmes bucais, e analisaram as associações entre 40 espécies bacterianas presentes na microbiota subgengival de indivíduos com periodontite crônica (SOCRANSKY et al.,1998). Os autores observaram a presença de 5 complexos bacterianos principais neste ambiente subgengival, de acordo com a relação entre as diferentes espécies. Um dos complexos, composto pelas espécies $T$. forsythia, $P$. gingivalis e Treponema denticola, denominado por estes autores complexo vermelho, foi fortemente 
relacionado com profundidade de sondagem e sangramento à sondagem. Outro complexo, o laranja, que parece preceder a colonização do complexo vermelho foi dividido em 2 grupos, um central, composto por F. nucleatum, Fusobacterium periodonticum, Prevotella intermedia, Prevotella nigrescens e Peptostreptococcus micros; e outro grupo periférico, formado por Eubacterium nodatum, Campylobacter rectus, Campylobacter showae, Campylobacter gracilis e Streptococcus constellatus. Os outros 3 complexos, o amarelo, o verde e o roxo, demonstraram grande associação entre si e menor associação com os 2 primeiros, e são compostos por diversas espécies consideradas compatíveis com o hospedeiro. O complexo verde é formado por Capnocytophaga sputigena, Capnocytophaga gingivalis, Capnocytophaga ochracea, E. corrodens e A. actinomycetemcomitans sorotipo a; o complexo amarelo é composto por um grupo de estreptococos: Streptococcus mitis, Streptococcus sanguinis, Streptococcus oralis, Streptococcus gordonii e Streptococcus intermedius; e o complexo roxo inclui Actinomyces odontolyticus e Veillonella parvula. As espécies de Selenomonas noxia e A. actinomycetencomitans sorotipo b não se correlacionaram com outras espécies. Posteriormente, algumas espécies de actinomicetos (Actinomyces gerencseriae, Actinomyces israelii, Actinomyces naeslundii sorotipos 1 e 2) foram agrupadas no complexo azul (SOCRANSKY; HAFFAJEE, 2002). Apenas recentemente, a técnica do checkerboard DNA-DNA hybridization foi usada para analisar o perfil microbiológico de indivíduos com periodontite agressiva generalizada, brasileiros (FAVERI et al., 2009) e mexicanos (XIMENEZ-FYVIE et al., 2006). Os resultados obtidos por estes autores apontaram níveis, proporções e prevalência elevados de espécies do complexo laranja e vermelho no biofilme subgengival do grupo com periodontite agressiva quando comparados com indivíduos saudáveis. A análise da microbiota pelo emprego de sondas de DNA apresenta várias vantagens, como permitir a identificação e quantificação de muitas espécies bacterianas em grande número de amostras. No entanto, a sua maior desvantagem refere-se a analisar apenas microrganismos pré-selecionados, não sendo eficaz na busca de novas espécies.

Entre as ferramentas de diagnóstico microbiológico empregadas para o estudo do ecossistema microbiano subgengival relacionado à periodontite agressiva generalizada destaca-se a diversidade filogenética por análise de bibliotecas do gene $16 \mathrm{~S} r R N A$. A alta especificidade e a natureza cumulativa dos bancos de dados de genes dos RNA 
ribossômicos (rRNA) têm incentivado a descoberta e o reconhecimento desta diversidade. O gene $r R N A$ tem regiões de consenso que são conservadas pelos organismos pertencentes ao mesmo domínio de vida, e regiões de variabilidade que são específicas de grupos e espécies particulares (WOESE et al., 1990). Através desta técnica, estima-se que a cavidade bucal abrigue aproximadamente 700 espécies bacterianas (PASTER et al., 2001; KAZOR et al. 2003). O estudo da diversidade consiste na extração do DNA da amostra, amplificação da região do gene $16 S r R N A$ com a utilização de iniciadores universais, clonagem do amplicon em Escherichia coli e sequenciamento genético (OLSEN et al., 1986). Mais recentemente, técnicas empregando seqüenciamento em profundidade (deep sequencing) estão permitido o estudo da diversidade microbiana de diversos nichos com maiores detalhes, mas até o momento não foram publicados resultados sobre a diversidade microbiana da cavidade bucal com emprego destas técnicas.

A análise da diversidade da microbiota subgengival de indivíduos com periodontite agressiva generalizada foi realizada por Faveri et al. (2008), através de sequenciamento da subunidade menor do RNA ribossômico (SSU $r R N A$ ) de Bacteria, e foi demonstrado que $50 \%$ dos clones foram representados por filotipos ainda não cultiváveis. Espécies de Selenomonas e Streptococcus foram encontradas em alta prevalência e proporção, sendo que cerca de $50 \%$ dos clones nas bibliotecas eram formados por estes gêneros. Esses dados sugerem que outras espécies bacterianas podem estar relacionadas à patogênese desta doença, além das reconhecidas por métodos dependentes de cultura e pelo emprego de sondas.

\subsection{ECOLOGIA MICROBIANA PERIODONTAL}

A inesgotável busca pelo estabelecimento dos fatores etiológicos da periodontite agressiva, assim como para qualquer doença polimicrobiana, deve-se a representação de um processo dinâmico, no qual várias espécies microbianas dominam o biofilme em diferentes fases da infecção devido às mudanças na disponibilidade nutricional, nível de oxigênio e pH local. $\mathrm{O}$ estudo da gengivite experimental conduzido por Löe, Theilade e Jensen (1965), durante um período superior a 28 dias, demonstrou que a placa sofre alterações na sua composição. Inicialmente caracterizada por bactéria Gram-positiva, principalmente cocos, passando para uma composição variada de morfotipos Gram- 
negativos, incluindo bacilos, organismos filamentosos, víbrios e espiroquetas, o que culmina no desenvolvimento da gengivite.

O conhecimento das relações ecológicas entre as espécies bacterianas pode direcionar e focar a investigação em uma interação bacteriana crítica, visto que as doenças infecciosas polimicrobianas são provocadas por um desequilíbrio da relação intermicrobiana no sítio subgengival ou pela relação entre a microbiota e o hospedeiro. Considerando que a homeostase microbiana é resultado do balanço dinâmico das interações microbianas, incluindo o sinergismo e o antagonismo (SANDERS et al., 1984), já foi postulada a hipótese de prevenção da doença não somente pela inibição de patógenos putativos, mas também pela interferência nos fatores responsáveis pela transição da microbiota do biofilme de comensal para patogênica (MARSH, 1994; KOLENBRANDER et al., 2005).

A ecologia microbiana representa a relação entre os microrganismos e seus habitats. Um conceito chave na ecologia microbiana é o ecossitema. Um ecossistema é o complexo de microrganismos em um ambiente específico e as adjacências não-microbianas às quais os organismos estão associados. Em um ecossistema em desenvolvimento, inicialmente ocorre a colonização pelos microrganismos pioneiros, que aderem aos tecidos do hospedeiro e posteriormente ligam-se a outras células microbianas por coagregação. Estas espécies pioneiras alteram o habitat, tornando-o favorável para a colonização de outras espécies que as substituem.

Existem dois tipos de sucessão microbiana $\mathrm{Na}$ sucessão autogênica, as espécies residentes alteram o ambiente de maneira tal que ocorre sua substituição por espécies mais favorecidas naquele habitat. Na sucessão alogênica, um tipo de comunidade é substituída por outra porque o habitat é alterado por fatores não microbianos como alterações alterações físicas e químicas nas propriedades das regiões ou alterações promovidas pelo hospedeiro. Certos fatores limitam a colonização. A exclusão de uma espécie por outra que desempenha as mesmas atividades pode ocorrer pelo uso dos nutrientes e/ou ocupação do sítio físico. No ambiente subgengival, a colonização inicial parece envolver membros do complexo amarelo, verde e roxo além de espécies de Actinomyces (SOCRANSKY et al., 1998). Então, ocorre a sucessão autogênica na qual membros dos complexos laranja e vermelho se tornam dominantes. A presença de níveis elevados dos últimos dois complexos 
hipoteticamente leva a alteração do habitat, induzindo a manifestação clínica da doença. A doença, em troca, favorece a proliferação de membros não só dos complexos laranja e vermelho, mas também dos colonizadores primários (SOCRANSKY; HAFFAJEE, 2005).

Neste contexto, organismos do domínio Archaea, de difícil cultivo, isolamento e purificação em condições normais de laboratório foram detectados no ambiente subgengival de humanos através do uso de técnicas moleculares. Entre os Archaea, os metanogênicos, apresentam a propriedade de consumir o hidrogênio $\left(\mathrm{H}_{2}\right)$ e o dióxido de carbono $\left(\mathrm{CO}_{2}\right)$, para a produção de metano. Membros do gênero Methanobrevibacter são anaeróbios estritos, produtores de metano, que se favorecem da condição de anaerobiose presente no biofilme subgengival (ROBICHAUX; HOWELL; BOOPATHY, 2003b; LEPP et al., 2004). Esta característica de serem oxidantes terminais, em comunidades microbianas complexas, os torna vitais na degradação microbiana anaeróbica de compostos orgânicos em ambientes naturais e também em nichos ecológicos definidos do corpo humano (ROBICHAUX; HOWELL; BOOPATHY, 2003b; VIANNA et al., 2006), podendo possivelmente participar do desencadeamento da doença através de alterações ecológicas no ambiente subgengival.

\subsection{ARCHAEA E O ECOSSISTEMA MICROBIANO HUMANO}

Archaea representa um dos três domínios da vida e são microrganismos procariontes distintos de Bacteria, com diferentes propriedades metabólicas, devido às características de organização do genoma, expressão gênica, composição celular e filogenia (MADIGAN et al., 2004). Compreendem os microrganismos anaeróbios mais sensíveis ao oxigênio, os termófilos mais extremos e halófilos cujas enzimas são adaptadas a elevadas concentrações salinas (CAVICCHIOLI et al., 2004).

Microrganismos Archaea foram primeiramente isolados na década de 70, de ambientes considerados extremamente inóspitos, caracterizados por apresentar temperaturas bastante elevadas, extrema acidez, alta salinidade, e, muitas vezes, ausência completa de oxigênio (LOUIS; FITT, 1972; MCCONNELL; SEARCY; SUTCLIFFE, 1978). Com o advento da biologia molecular, o estudo da relação evolucionária entre os

seres vivos passou a ser muito mais revelador quando comparado à utilização de análise de fenótipos clássicos. A partir da comparação de seqüências de DNA que codificavam o 
RNA ribossômico (subunidades 16S e 23S) de diferentes organismos, Woese et al. (1990) demonstraram que a vida no planeta se divide em três grandes domínios, sendo que Archaea foram definidos como pertencentes ao terceiro domínio da vida. Com o maior número de estudos sobre este grupo, membros deste domínio foram também encontrados em ambientes aeróbios (LOSEKANN et al., 2007) e temperados (DELONG, 1992; EINEN; THORSETH; OVRE, 2008), e ainda fazendo parte da microbiota de animais (WRIGHT et al., 2004; SAENGKERDSUB et al., 2007; SKILLMAN et al., 2009) e de humanos (MILLER et al., 1982; BELAY et al., 1988; FERRARI et al., 1994).

Os ecossistemas humanos mais estudados quanto à presença de Archaea e a sua relação com doença são o trato intestinal (SCANLAN et al., 2008; DRIDI et al., 2009) e o ambiente subgengival (KULIK et al., 2001; LEPP et al, 2004; YAMABE et al., 2008; LI et al., 2009; VIANNA et al., 2009). As espécies de Archaea predominantemente encontradas são metanogênicas pertencentes ao gênero Methanobrevibacter, apesar de outras espécies dos gêneros Methanogenium, Methanosphaera e Methanosarcina também terem sido detectadas (MILLER et al., 1982; BELAY et al., 1990; FERRARI et al., 1994; KULIK et al., 2001; LEPP et al, 2004; WRIGHT et al., 2004; SAENGKERDSUB et al., 2007; MIHAJLOVSKI; ALRIC; BRUGERE, 2008; YAMABE et al., 2008; SCANLAN et al., 2008; LI et al., 2009; DRIDI et al., 2009; SKILLMAN et al., 2009). Estes organismos produzem metano a partir de vários substratos, como $\mathrm{H}_{2}$ e $\mathrm{CO}_{2}$, compostos de $\mathrm{C}_{1}$ metilado (metanol, metilaminas, metiltiois) ou acetato (DEPPENMEIER, 2002).

\subsubsection{Archaea e o Trato Intestinal}

A principal espécie metanogênica detectada no intestino é a Methanobrevibacter smithii, e em menor freqüência Methanosphera stadmaniae (SCANLAN et al., 2007; MIHAJLOVSKI; ALRIC; BRUGERE, 2008; DRIDI et al., 2008). Rutili et al. (1996) determinaram que Archaea metanogênicos são detectados no intestino somente após os 2 anos de idade e a prevalência de metanogênicos aumenta para $40 \%$ aos 3 anos e $60 \%$ aos 5 anos de idade em humanos. Apesar de a deteç̧ão coincidir com a mudança para a dieta do adulto, o principal gênero encontrado nos ecossistemas do corpo humano, Methanobrevibacter sp., não foram encontrados em alimentos (BRUSA; FERRARI; CANZI, 1998). 
Comparações quanto à detecção do domínio são dificultadas pelas diferenças metodológicas entre os estudos. Alguns avaliam a porcentagem de indivíduos que excretam metano por cromatografia gasosa (MCKAY et al., 1983; PIQUÉ et al., 1984; PELED et al., 1987), outros fazem contagem direta nas fezes (WEAVER et al., 1986), outros ainda avaliam a freqüência de Archaea por deteç̧ão por reação em cadeia da polimerase (PCR) em extratos fecais. De maneira geral, $40-50 \%$ dos indivíduos adultos saudáveis ou sem problemas gastrointestinais apresentam microrganismos metanogênicos compondo a sua microbiota intestinal, verificado através da excreção de metano por cromatografia gasosa ou por ensaios de PCR (PIQUÉ et al., 1984; SCANLAN et al, 2008). Quando lesões malignas são consideradas, a proporção dos indivíduos que excretam metano é superior a 80\% (PIQUÉ et al., 1984). Por outro lado, a análise da freqüência de Archaea por PCR em indivíduos com doença inflamatória do intestino (Síndrome de Chron e Colite Ulcerativa) está em torno de 30\% (SCANLAN et al, 2008), possivelmente pela perda de metanogênicos de crescimento lento durante as condições de rápido trânsito intestinal. Existem, ainda, evidências de que os níveis de metanogênicos diferem entre as populações, sendo que a proporção de produtores de metano na população adulta humana dos Estados Unidos e da Grã-Bretanha é maior do que no Japão (MORII et al., 2003).

\subsubsection{Archaea e a Cavidade Bucal}

A correlação entre a presença, a diversidade e a quantidade de metanogênicos com doenças da cavidade bucal e sua severidade foi estudada por vários grupos de pesquisa em amostras de canais radiculares (SIQUEIRA et al., 2005; VIANNA et al., 2006; VICKERMAN et al., 2007) e de sítios periodontais (BELAY et al., 1988; FERRARI et al., 1994; KULIK et al, 2001; LEPP et al., 2004; YAMABE et al., 2008; LI et al., 2009; VIANNA et al., 2009).

A presença de metanogênicos em sítios com infecção endodôntica foi investigada em 96 amostras de canais radiculares, usando PCR (SIQUEIRA et al., 2005). As amostras foram coletadas de canais radiculares tratados e não-tratados de indivíduos com lesão endodôntica crônica ou com abscesso agudo. O domínio Bacteria também foi investigado e detectado em todas as amostras, mas Archaea não foi detectado em nenhuma delas. Contrariando o estudo descrito acima, estes organismos foram detectados em sítios 
endodônticos por dois grupos de pesquisa (VIANNA et al., 2006; VICKERMAN et al., 2007). Vinte dentes uniradiculares com necrose pulpar foram investigados para a presença de metanogênicos (VIANNA et al., 2006). Ensaios de PCR em tempo real foram usados para amplificar o gene $\operatorname{mcr} A$, que codifica a enzima envolvida na metanogênese distinguindo os metanogênicos, e o gene $16 S$ rRNA de Archaea. Cinco das 20 amostras apresentaram metanogênicos pertencentes ao gênero Methanobrevibacter. A quantidade total de Archaea variou, atingindo mais de 2,5\% da população procarionte. A presença de metanogênicos relacionados ao gênero Methanobrevibacter em canais radiculares foi confirmada por Vickerman et al. (2007) que detectaram estes microrganismos em 2 das 34 amostras analisadas.

O primeiro estudo relatando a presença de metanogênicos no biofilme subgengival de humanos utilizou cultura e foi publicado no final dos anos 80 (BELAY et al., 1988). Entre 54 amostras de 36 indivíduos analisados, 20 foram positivas para organismos metanogênicos, e haviam sido obtidas de 9 indivíduos com algum comprometimento periodontal. Entre 14 amostras de sítios saudáveis ou com periodontite leve, 7\% produziram metano a partir do $\mathrm{H}_{2} / \mathrm{CO}_{2}$ [80/20 (vol/vol)] disponibilizado como substrato, enquanto $26 \%$ de 23 amostras provenientes de periodontite moderada e $76 \%$ de 17 amostras de periodontite avançada apresentavam o mesmo produto do metabolismo. Assim, os dados indicaram que a prevalência de metanogênicos foi maior entre os indivíduos com periodontite moderada a avançada do que entre indivíduos com periodonto saudável ou com periodontite leve.

Ensaios de PCR foram utilizados em estudos mais recentes (KULIK et al., 2001; LEPP et al.; 2004; YAMABE et al., 2008; LI et al., 2009) para determinar a prevalência e a identidade de microrganismos do domínio Archaea em amostras de biofilme subgengival. Um par de iniciadores domínio-específico foi utilizado para detectar o gene da SSU rRNA de Archaea em um pool de amostras de biofilme subgengival de 48 indivíduos com comprometimento periodontal (KULIK et al., 2001). Neste estudo, 77\% dos indivíduos apresentaram amplicons para o gene alvo. Methanobrevibacter oralis foi a principal espécie encontrada no biofilme dental entre as sequências obtidas de amostras periodontais. No entanto, não houve associação entre os parâmetros clínicos da doença e a presença de Archaea. 
Lepp et al. (2004) avaliaram amostras de biofilme subgengival de indivíduos com periodonto saudável e com perda de inserção periodontal quanto à presença e identidade de Archaea. O DNA de Archaea (16S rRNA) não foi detectado em nenhuma das amostras da população controle saudável, que era composta por 8 indivíduos, mas 36\% das 50 amostras com periodontite (sem distinção entre doença crônica ou agressiva) albergavam estes microrganismos. A SSU $r R N A$ de Archaea foi detectada em 76,6\% dos sítios com periodontite, mas não em amostras de sítios saudáveis e nem de saburra lingual dos indivíduos com comprometimento periodontal. O número de cópias de Archaea aumentou de acordo com a severidade da doença periodontal no sítio amostrado e a abundância relativa deste domínio em relação ao total de procariotos foi significantemente maior em sítios com periodontite severa e moderada do que em sítios com periodontite leve em indivíduos positivos para Archaea. A comunidade de Archaea em sítios doentes foi dominada por um filotipo semelhante a M. oralis. Como somente alguns sítios de indivíduos com doença severa apresentaram Archaea, os autores sugeriram a exclusão dos organismos metanogênicos por outros microrganismos metabolizadores de hidrogênio, como os treponemas, que foram encontrados em proporções significantemente menores em sítios onde os microrganismos do domínio Archaea foram detectados.

Utilizando o mesmo iniciador descrito por Lepp et al. (2004) e com o objetivo de demonstrar o potencial patogênico do domínio Archaea na doença periodontal, Yamabe et al. (2008) investigaram a distribuição de Archaea em indivíduos japoneses com periodontite e examinaram a resposta sérica de IgG aos componentes de Archaea. Amostras de biofilme subgengival foram coletadas de 111 sítios periodontais de 49 indivíduos (17 com periodontite agressiva e 32 com periodontite crônica) e 30 amostras de biofilme subgengival foram coletados de indivíduos saudáveis. Archaea foi detectado em 15 amostras subgengivais (13,5\% do total de amostras) de 11 indivíduos (29,4\% dos indivíduos com periodontite agressiva e 18,8\% dos indivíduos com periodontite crônica). Este domínio foi detectado em 14 de 15 sítios com PS $\geq 6 \mathrm{~mm}$, enquanto nenhum amplicon foi observado a partir de 30 amostras de sítios sem perda de inserção em indivíduos controles saudáveis. A análise do sequenciamento dos produtos de PCR revelou que a maioria dos organismos Archaea presentes nas bolsas periodontais pertencem a filotipos semelhantes a $M$. oralis. A análise da resposta do sistema imune humoral do hospedeiro 
por Western Blotting detectou anticorpos IgG contra M.oralis em 8 dos 11 soros analisados, indicando o reconhecimento dos componentes do domínio Archaea pelo sistema imune.

Recentemente, utilizando dois pares de iniciadores cuja eficiência e sensibilidade já tinham sido testadas na literatura (KULIK et al., 2001; LEPP et al., 2004). Li et al. (2009) propuseram mais uma sonda para identificação deste domínio e investigaram a prevalência e a diversidade molecular de Archaea em 41 indivíduos com periodontite crônica e em 15 indivíduos saudáveis. A prevalência de Archaea demonstrada com o par de iniciadores descrito por Kulik et al. (2001) foi de 73,2\%, enquanto com o par de iniciadores utilizado por Lepp et al. (2004) foi de 70,7\%. Archaea não foi detectado em indivíduos saudáveis. Com o iniciador proposto por Lepp et al. (2004) todas as sequências de amplicons foram identificadas como M. oralis. Com a nova sonda, além de sequências identificadas como M. oralis, um outro filotipo foi identificado como pertencente à classe Termoplasma. Mais uma vez, a limitada diversidade de Archaea associada à periodontite foi demonstrada.

Vianna et al. (2008) avaliaram amostras de biofilme de 102 indivíduos com comprometimento periodontal quanto a onipresença e proporção de Archaea metanogênicos, redutores de sulfato e acetogênicos, grupos que dependem da metabolização do $\mathrm{H}_{2}$, sendo conhecidos como hidrogenotróficos. Os hidrogenotróficos foram quase que consistentemente detectados nas bolsas periodontais, mas não em sítios de indivíduos com periodonto saudável, sendo as proporções de metanogêncos e de redutores de sulfato significantemente mais elevadas nos casos severos. Além disso, interações antagonistas entre os três grupos microbianos indicaram que eles podem funcionar em parcerias sintróficas alternativas para patógenos periodontais fermentadores secundários. A freqüência de metanogênicos em indivíduos com comprometimento periodontal, utilizando iniciadores para o gene $\operatorname{mcr} A$, foi de $43,1 \%$.

Mais recentemente, Vianna et al. (2009) utilizaram análise do polimorfismo do comprimento de fragmentos de restrição terminal complementada por análise clonal e sequenciamento dos genes $m c r A$ e $16 S r R N A$ para avaliar a diversidade de metanogênicos nos biofilmes orais. Foram selecionadas amostras de biofilme subgengival de 44 indivíduos positivos para a presença de metanogênicos de um estudo prévio (VIANNA et al., 2008). A placa subgengival dos 4 sítios periodontais mais profundos de cada indivíduo foi coletada com cones de papel e o pool destas amostras foi analisado. M. oralis foi o único organismo 
metanogênico em 39 amostras periodontais enquanto um novo tipo de seqüência do gene mcrA foi detectado em cinco amostras periodontais sugerindo o envolvimento de um novo filotipo metanogênico, ainda não cultivado com as infecções orais.

Apesar das evidências existentes na literatura da participação de Archaea na microbiota em humanos, ainda não são conhecidos exemplos de patógenos do terceiro domínio de vida. Também não está bem clara a contribuição de Archaea para a patogênese da doença periodontal em humanos. Existe um consenso de que este domínio possui uma relação indireta com as doenças infecciosas, favorecendo o crescimento de outros microrganismos, os quais, por sua vez, estão diretamente envolvidos na patogênese (LEPP et al., 2004; VIANNA et al., 2006; CONWAY DE MACARIO; MACARIO, 2008; HIGUCHI et al., 2009). É interessante estabelecer se a presença e diferentes níveis de metanogênicos em humanos possuem valor diagnóstico e prognóstico em relação às condições patológicas com as quais eles podem estar associados. 


\section{OBJETIVOS}

O objetivo geral do presente estudo foi testar a hipótese de que Archaea poderia estar associada à periodontite agressiva.

Assim, os objetivos específicos deste estudo foram:

- avaliar a prevalência do domínio Archaea,

- determinar a diversidade de microrganismos do domínio Archaea, -determinar a proporção de Archaea em relação ao domínio Bactéria, em amostras de biofilme subgengival de indivíduos com periodontite agressiva e comparalas a amostras obtidas de indivíduos com saúde periodontal. 


\section{MATERIAL E MÉTODOS}

\subsection{OBTENÇÃO DAS AMOSTRAS CLÍNICAS}

\subsubsection{Seleção da População}

Após a apreciação e aprovação do projeto pelo Comitê de Ética em Pesquisa do ICB/USP, foram analisadas amostras de biofilme subgengival de 60 indivíduos que compareceram à Clínica Odontológica da Universidade de Guarulhos. Todos os participantes foram informados sobre os objetivos do estudo, seus riscos e benefícios, incluindo os tipos de medições clínicas, forma de coleta de amostras e terapias que seriam realizadas. Os indivíduos que concordaram em participar do estudo assinaram um Termo de Consentimento Livre e Esclarecido (ANEXO A), responderam a um questionário de saúde/anamnese e, quando necessário, receberam a terapia periodontal, estando de acordo com as diretrizes e normas do Conselho Nacional de Saúde (Resolução n 196/96).

\subsubsection{Critérios de Inclusão e Exclusão}

\subsubsection{Critérios de inclusão}

a) Saúde Periodontal (SP)

Foram incluídos neste estudo 30 indivíduos com saúde periodontal foram selecionados para este estudo. Estes indivíduos apresentavam idade superior ou igual a 20 anos e no mínimo 20 dentes, excluindo-se os terceiros molares. Foram considerados periodontalmente saudáveis aqueles que não apresentavam profundidade de sondagem e/ou nível clínico de inserção maior do que $4 \mathrm{~mm}$, ausência de sinais clínicos de gengivite generalizada e índice de sangramento à sondagem inferior à $30 \%$.

b) Periodontite Agressiva Generalizada (PA)

Trinta indivíduos com periodontite agressiva, com idade inferior ou igual a 30 anos e apresentando no mínimo 20 dentes, excluindo-se os terceiros molares. O diagnóstico de periodontite agressiva foi baseado nos critérios estabelecidos pela Academia Americana de Periodontia (ARMITAGE, 1999). Resumidamente, para caracterizar a periodontite agressiva generalizada, os indivíduos deveriam apresentar no mínimo 8 dentes com pelo menos 1 sítio interproximal, não-contíguo, com perda de inserção maior ou igual a $4 \mathrm{~mm}$. 
Estes sítios deveriam estar distribuídos em pelo menos 3 dentes diferentes dos primeiros molares e incisivos.

\subsubsection{Critérios de Exclusão}

Os critérios de exclusão empregados neste estudo foram: ser fumante; estar grávida ou amamentando; ter realizado tratamento periodontal previamente; uso de antibióticos sistêmicos nos últimos 12 meses; ter utilizado antissépticos bucais nos últimos seis meses; ter história de doença sistêmica que comprometa a resposta do hospedeiro ou exija medicação profilática ao tratamento.

\subsubsection{Avaliação Clínica}

As mensurações clínicas foram realizadas em seis sítios por dente (mesiovestibular, vestibular, distovestibular, mesiolingual, lingual, distolingual), em todos os dentes (exceto terceiros molares) utilizando-se sonda periodontal milimetrada Carolina do Norte PCPUNC-BR 15 (HuFriedy do Brasil, Rio de Janeiro, RJ, Brasil). Os parâmetros clínicos avaliados incluiram:

-Índice de placa visível - IPV (AINAMO; BAY, 1975): presença (escore 1) ou ausência (escore 0) de placa dentária supragengival visível, após lavagem e secagem dos dentes.

-Índice de sangramento gengival - ISG (AINAMO; BAY, 1975): presença (escore 1) ou ausência (escore 0) de sangramento na gengiva marginal após percorrer levemente a sonda periodontal ao longo do sulco gengival.

-Profundidade de sondagem - PS: distância, em milímetros, entre a margem gengival livre e a porção mais apical sondável do sulco/bolsa periodontal.

-Nível clínico de inserção - NCI: distância, em milímetros, entre a junção esmalte-cemento e a porção mais apical sondável do sulco/bolsa periodontal.

-Sangramento à sondagem - SS: presença (escore 1) ou ausência (escore 0) de sangramento após 20 segundos da sondagem com sonda periodontal milimetrada.

-Supuração: presença (escore 1) ou ausência (escore 0) de supuração após 20 segundos da sondagem com sonda periodontal milimetrada. 
O exame clínico periodontal foi realizado por um único examinador, treinado e calibrado pelo método preconizado por Araújo et al. (2003), onde o erro padrão da medida e o erro médio percentual são calculados para cada um dos parâmetros clínicos periodontais contínuos (profundidade de sondagem e nível clínico de inserção). Para as variáveis categóricas (índice de placa visível, índice de sangramento gengival e samgramento à sondagem), considerando somente a presença ou a ausência do parâmetro clínico, foi realizada a média do nível de concordância para o examinador (Teste Kappa). O erro padrão da medida e o erro médio percentual foram de $0,14 \mathrm{~mm}$ e $4,3 \%$ para a profundidade de sondagem e de 0,31 mm e 7,9 \% para o nível clínico de inserção, respectivamente. Enquanto a média do nível de concordância para o examinador considerando as variáveis categóricas, revelou uma concordância superior a 92 \% (Teste Kappa).

\subsubsection{Seleção dos Sítios Testes}

Com base no exame clínico, 9 sítios interproximais por indivíduo foram aleatoriamente selecionados para a análise microbiológica. No grupo periodontite agressiva generalizada, foram coletadas amostras de biofilme subgengival de 3 sítios rasos (PS $\leq 3 \mathrm{~mm}$ ), 3 sítios moderados (PS entre 4-6mm) e 3 sítios produndos (PS $\geq 7 \mathrm{~mm}$ ). Quando o indivíduo não possuía 3 sítios com $\mathrm{PS} \geq 7 \mathrm{~mm}$, foram coletados sítios intermediários (entre 4-6mm) para completar os 9 sítios. Nos indivíduos com saúde periodontal foram coletados 9 sítios com $\mathrm{PS} \leq 3 \mathrm{~mm}$ que não apresentavam sangramento à sondagem.

\subsubsection{Coleta das Amostras de Biofilme Subgengival}

Após a remoção da placa supragengival, a coleta de amostras de biofilme subgengival foi feita com curetas Gracey do tipo mini-five (HuFriedy, Brasil), posicionadas na porção mais apical dos sítios selecionados. As amostras foram depositadas em tubos de polipropileno de 1,5 mL contendo $100 \mu \mathrm{L}$ de solução TE (10 mM Tris-HCl, 0,1mM EDTA, pH 7,6). Esses tubos plásticos foram previamente identificados com o código do indivíduo, data e sítio, e após a coleta foram armazenados sob refrigeração a $-20^{\circ} \mathrm{C}$ até o momento da análise. 


\subsection{EXTRAÇÃO DE DNA}

A extração de DNA foi realizada de acordo com metodologia descrita por Dewhirst et al. (2000). A $44 \mu \mathrm{L}$ da amostra inicial, foram adicionados $1 \mu \mathrm{L}$ de solução de proteinase K em uma concentração de $200 \mu \mathrm{g} / \mathrm{mL}$ (Sigma Chemical Co., St. Louis, MO, EUA) e $5 \mu \mathrm{L}$ de solução de Tween 20 (Vetec Química Fina Ltda, Rio de Janeiro, RJ, Brasil) a 5\%. A amostra foi aquecida a $55{ }^{0} \mathrm{C}$ durante $2 \mathrm{hs}$ e, posteriormente, a $95{ }^{0} \mathrm{C}$ por $10 \mathrm{~min}$, para inativação da Proteinase K em termociclador (Peltier Thermal Cycles PTC-200, MJ Research, Inc., Watertown, MA, EUA).

\subsection{SELEÇÃO DOS INICIADORES PARA A REAÇÃO DE AMPLIFICAÇÃO DO GENE $16 S$ rRNA DE ARCHAEA}

As bibliotecas genômicas de dois pares de iniciadores domínio-específicos para Archaea, descritos em estudos prévios que avaliaram amostras de infecções periodontais (KULIK et al., 2001; LEPP et al., 2004; VIANNA et al., 2006; VICKERMAN et al., 2007; YAMABE et al., 2008; LI et al., 2009) foram determinadas através de reações de amplificação da região $16 S$ rRNA de Archaea (item 3.4 Prevalência de Archaea), clonagem e sequenciamento (item 3.5.1 Clonagem e Sequenciamento do gene $16 S$ rRNA). O DNA extraído de amostras clínicas de periodontite agressiva de sítios distintos, um profundo e um raso, de um mesmo indivíduo foi utilizado como molde. $\mathrm{O}$ par de iniciadores que apresentou a maior biblioteca genômica foi o escolhido para o prosseguimento do estudo. A seqüência e o tamanho do produto dos iniciadores avaliados estão apresentados na Tabela 1, assim como a temperatura de anelamento, utilizada pelo presente estudo, para obtenção de bandas bem definidas. 
Tabela 1- Iniciadores analisados e condições para detecção do domínio Archaea.

\begin{tabular}{|c|c|c|c|}
\hline Referência & Seqüência nucleotídica & $\begin{array}{l}\text { Anelamento } \\
\left({ }^{\circ} \mathrm{C}\right)\end{array}$ & $\begin{array}{l}\text { Produto } \\
(\mathrm{pb})\end{array}$ \\
\hline Kulik et al. (2001) & $\begin{array}{l}\text { 5'-AGC(A/G)(A/G)GAGCCCGGAGATGG-3' } \\
\text { 5'-CGGCGTTGA(A/G)TCCZZTTAAAC-3' }\end{array}$ & 64 & 654 \\
\hline Lepp et al. (2004) & $\begin{array}{l}\text { 5'-YCCGGCGTTGAMTCCAATT-3', } \\
\text { 5'-TGTGTGCAAGGAGCAGGGAC-3', }\end{array}$ & 60 & 572 \\
\hline
\end{tabular}

A temperatura de anelamento indica a adaptação a partir da referência citada.

\subsection{PREVALÊNCIA DE ARCHAEA}

Para a análise das amostras clínicas, foi utilizado como molde $1 \mu \mathrm{L}$ do DNA extraído do biofilme subgengival de indivíduos com periodontite agressiva e com saúde periodontal, conforme descrito no item 3.2 Extração de $D N A$. A reação consistiu de $\mathrm{MgCl}_{2}$ (2 mM), dNTP (0,2 mM), $5 \mu \mathrm{L}$ de tampão de PCR 10X, 25 pmol de cada par de iniciadores, 2 U de Platinum $^{\circledR}$ Taq DNA Polimerase e água estéril, para um volume total de $50 \mu \mathrm{L}$ de reação (KULIK et al., 2001). As reações de amplificação foram realizadas sob as seguintes condições: desnaturação inicial a $94{ }^{\circ} \mathrm{C}$ por $4 \mathrm{~min}$, seguida de: 35 ciclos de desnaturação a $95^{\circ} \mathrm{C}$ por $15 \mathrm{~s}$, anelamento a $64^{\circ} \mathrm{C}$ por $30 \mathrm{~s}$ e extensão a $72{ }^{\circ} \mathrm{C}$ por $15 \mathrm{~s}$, e extensão final a $72{ }^{\circ} \mathrm{C}$ por 7 min em termociclador (Gen Amp PCR System 2400, Applied Biosystems, Foster City, CA, EUA). Como controle positivo foi utilizado como molde o DNA extraído de um consórcio de Archaea metanogênicas ambientais cedida pela Profa. Dra. Vivian Pelizzari do Laboratório de Microbiologia Ambiental do ICBII/USP, e como controle negativo água milliQ.

Os produtos foram submetidos à corrida eletroforética em gel de agarose (Gibco) a 1\%, em tampão Tris Acetato EDTA (TAE - Tris acetato 40 mM, pH 8,5; EDTA $2 \mathrm{mM}$ ) e corados com brometo de etídio (Sigma-Aldrich, Inc., St. Louis, MO, EUA). Os fragmentos de 500-700 pb, correspondentes à detecção do gene que codifica SSU rRNA de Archaea foram visualizados e documentados (Photo PC 3100Z, Epson, Hemel Hempstead, Inglaterra) sob luz ultravioleta (Pharmacia Biotech, modelo UV20, São Francisco, CA, EUA). 


\subsection{DIVERSIDADE DE ARCHAEA}

$\mathrm{O}$ estudo da diversidade de Archaea foi determinado por sequenciamento do gene I6S rRNA obtido a partir da amplificação do DNA de amostras de um único sítio positivo por indivíduo de 10 indivíduos do grupo PA (somente sítios com PS $\geq 7 \mathrm{~mm}$ ) e 10 indivíduos do grupo SP (PS $\leq 3 \mathrm{~mm})$.

\subsubsection{Clonagem e Sequenciamente do gene $16 S r R N A$}

Após a determinação da presença de amplicons obtidos como descrito no item 3.4 Prevalência de Archaea, os produtos foram excisados do gel e purificados usando o kit comercial QIAquick PCR (Qiagen, Hilden, Alemanha), seguindo as instruções do fabricante. Os fragmentos purificados foram ligados ao vetor TOPO TA Cloning (Invitrogen Life Technologies, Carlsbad, CA, EUA) e a mistura de ligação transformada em células eletrocompetentes de E. coli, por eletroporação. Meio SOC (Meio SOB- 20 $\mathrm{mg} / \mathrm{mL}$ de triptona, $5 \mathrm{mg} / \mathrm{mL}$ de extrato de levedura, $0,5 \mathrm{mg} / \mathrm{mL}$ de $\mathrm{NaCl}, \mathrm{KCl}$ na concentração final de 2,5 mM; enriquecido com glicose filtrada a uma concentração final de $20 \mathrm{mM}$ ) foi adicionado à suspensão de células, seguindo-se incubação sob agitação a $120 \mathrm{rpm}$ a $37^{\circ} \mathrm{C}$ por $1 \mathrm{~h}$. As células transformantes foram então selecionadas pelo cultivo a $37^{\circ} \mathrm{C}$ por uma noite em ágar Luria-Bertani (LB, $10 \mathrm{~g} / \mathrm{L}$ triptona, $5 \mathrm{~g} / \mathrm{L}$ extrato de levedura, $2,5 \mathrm{~g} / \mathrm{L} \mathrm{NaCl}$, e $20 \mathrm{~g} / \mathrm{L}$ agar) acrescido de $50 \mu \mathrm{g} / \mathrm{mL}$ de ampicilina. Cerca de 100 colônias obtidas a partir de cada amostra do grupo periodontite agressiva e do grupo saúde periodontal, selecionadas aleatoriamente, foram transferidas para outra placa de ágar LB contendo ampicilina, seguindo um escantilhão, e cultivadas a $37^{\circ} \mathrm{C}$ por uma noite. Posteriormente, as células de cada transformante foram transferidas para tubos contendo 40 $\mu \mathrm{L}$ de tampão $\mathrm{TE}$, e mantidas a $-80{ }^{\circ} \mathrm{C}$ até o momento do processamento. Alíquotas de 1 $\mu \mathrm{L}$ da suspensão de células em tampão TE foram utilizadas como DNA molde em reação de PCR usando os iniciadores existentes no vetor [TOPO TA Cloning Kit [PCR 2.1-TOPO vector, (5'-GTAAAACGACGGCCAG-3' e 5'-CAGGAAACAGCTATGAC-3'), Invitrogen] seguido por eletroforese em gel de agarose a $1 \%$, para verificação de produtos do tamanho esperado (700-900 pb). 
Os produtos das reações $16 S$ rRNA foram purificados para sequenciamento com auxílio do kit de purificação de produtos de PCR (Montage PCR Centrifugal Filter Device, Millipore Corporation, Bedford, MA, EUA).

Foram seqüenciados 48 clones/amostra obtidos do grupo PA e 24 clones/amostra do grupo SP. Para a reação de sequenciamento, empregando-se os iniciadores do vetor, foram utilizados como molde $5 \mu \mathrm{L}$ de cada produto de PCR. O seqüenciamento foi realizado utilizando o kit de sequenciamento ABI Prism (BigDye Terminator Cycle Sequencing kit with AmpliTaq DNA Polymerase FS; Perkin-Elmer, Foster City, CA, EUA). Foram utilizadas as bases fluorescentes (Big Dye) com 3,2 $\mu \mathrm{M}$ do iniciador reverso do par selecionado (KULIK et al., 2001), em volume total de $20 \mu \mathrm{L}$ por reação. Os ciclos de amplificação foram realizados em termociclador (Gen Amp PCR System 2400), com 35 ciclos de desnaturação a $96{ }^{\circ} \mathrm{C}(45 \mathrm{~s})$, anelamento de $64{ }^{\circ} \mathrm{C}(30 \mathrm{~s})$ e extensão a $60{ }^{\circ} \mathrm{C}(4$ min). Os fragmentos de DNA obtidos foram enviados ao Serviço de Seqüenciamento de DNA, do Instituto de Química da Universidade de São Paulo, onde foi realizado sequenciamento do inserto.

\subsubsection{Análise Filogenética}

A identificação das espécies/filotipos foi feita por comparação das seqüências de DNA obtidas, de aproximadamente 500 pares de base, com as seqüências publicadas em banco de dados (BLAST, GenBank) (PASTER et al., 2001). As sequências foram alinhadas usando o programa Bionumerics (Applied Maths, Inc., Austin, TX, EUA) e as árvores filogenéticas (dendrogramas) foram construídas segundo o método UPGMA, obtendo-se assim a posição filogenética do microrganismo (PASTER et al., 2001). Matrizes de similaridade foram construídas a partir do alinhamento das seqüências e da posição filogenética, e foram corrigidas para a mudança de bases pelo método descrito por Jukes e Cantor (1969). A identificação das espécies/filotipos foi feita por comparação com as seqüências publicadas em banco de dados (BLAST, GenBank) considerando como ponto de corte a similaridade de 99\% (PASTER et al., 2001; ACHTMAN; WAGNER, 2008; KEMP; ALLER, 2008). 


\subsubsection{Análise de Rarefação e Índice de Cobertura}

O número de unidades taxonômicas operacionais (OTUs) observadas por amostra foi determinado por um ponto de corte cujo valor de divergência máximo foi estabelecido em 3\% $\left(\mathrm{OTU}_{0,03}\right)$, usando o programa DOTUR (SCHLOSS; HANDELSMAN, 2005).

A análise de rarefação foi utilizada para comparar o número de OTUs observadas contra o número de clones seqüenciados em cada amostra. $\mathrm{O}$ ponto a partir do qual a curva alcança o platô estabelece que o sequenciamento de novos clones não irá aumentar a confiança e a precisão da estimativa (SCHLOSS; HANDELSMAN, 2005).

A análise de cobertura não-paramétrica de Good (GOOD, 1953) foi utilizada para estimar a representatividade dos filotipos existentes na amostra pela biblioteca obtida.

\subsection{ANÁLISE QUANTITATIVA DE MICRORGANISMOS DOS DOMÍNIOS ARCHAEA E BACTERIA}

A quantificação e a proporção de Archaea em relação ao total de procariontes foram estimadas em ensaios de PCR em tempo real. Amostras de biofilme gengival obtidas de 2 sítios profundos (PS $\geq 5 \mathrm{~mm}$ ) e 2 sítios rasos ( $\mathrm{PS} \leq 3 \mathrm{~mm}$ ) por indivíduo do grupo PA e 2 sítios por indivíduo do grupo SP foram aleatoriamente selecionadas para esta análise.

\subsubsection{Extração de DNA}

O DNA microbiano das amostras de biofilme subgengival foi extraído e purificado com Qiamp DNA mini kit (Qiagen) seguindo as instruções do fabricante. Todas as amostras selecionadas foram submetidas à quantificação de DNA $\left(\mathrm{A}_{260}\right)$ e análise da pureza ( $\left.\mathrm{A}_{260 / 280}\right)$ com auxílio do espectrofotômetro NanoDrop (NanoDrop ND 1000).

\subsubsection{Quantificação do Domínio Archaea}

\subsubsection{Estabelecimento dos padrões}

Para obtenção da curva padrão, utilizada como parâmetro na quantificação das amostras, foram utilizadas diluições sucessivas de plasmídeos apresentando uma cópia clonada de um fragmento de DNA codificando o gene $16 \mathrm{~S} r R N A$ de $M$. oralis, obtido neste estudo (item 3.5.1 Clonagem e Sequenciamento do gene $16 S$ rRNA) e estas usadas como DNA molde. 
Todas as reações foram processadas utilizando os iniciadores universais para Archaea, 931f (5'-AGGAATTGGCGGGGGAGCA-3') e m1100r (5'BGGGTCTCGCTCGTTRCC), cuja sensibilidade e especificidade foram demonstradas por Einen, Thorseth e Ovre (2008) e resultam em um produto de 195 pb. Para a reação de amplificação foi utilizando $0,5 \mu \mathrm{M}$ de cada iniciador (EINEN; THORSETH; OVRE, 2008), $1 \mu \mathrm{L}$ de DNA molde, $2,5 \mathrm{U}$ de Platinum $^{\circledR}$ Taq DNA Polimerase (Invitrogen), $5 \mu \mathrm{L}$ de tampão de PCR (10X) (Invitrogen), 0,8 $\mathrm{mM}$ de cada dNTP (Invitrogen), $2 \mathrm{mM}$ de $\mathrm{MgCl}_{2}$ (Invitrogen) em um volume final de $50 \mu \mathrm{L}$. As condições de amplificação do gene $16 S$ rRNA de microrganismos do domínio Archaea por PCR quantitativo compreenderam uma pré-incubação a $95^{\circ} \mathrm{C}$ por $15 \mathrm{~min}, 45$ ciclos de desnaturação a $94^{\circ} \mathrm{C}$ por $15 \mathrm{~s}$, anelamento a $64{ }^{\circ} \mathrm{C}$ por $30 \mathrm{~s}$ e extensão a $72{ }^{\circ} \mathrm{C}$ por $30 \mathrm{~s}$, seguidos por uma extensão final a $72{ }^{\circ} \mathrm{C}$ por 7 min. Os amplicons resultantes foram clonados em plasmídeo utilizando o kit TOPO, como descrito no item 3.5 Clonagem e Sequenciamento do gene $16 \mathrm{~S} r R N A$, e as colônias transformantes obtidas foram aleatoriamente selecionadas e ressuspensas em tampão TE.

As células em TE foram utilizadas como DNA molde em reação de amplificação utilizando os iniciadores existentes no vetor TOPO com a finalidade de confirmar a presença do inserto. As células recombinantes cujos amplicons apresentavam o tamanho esperado (395 pb) foram transferidas para caldo LB com ampicilina, e as culturas incubadas por $12 \mathrm{~h} \mathrm{a} 37{ }^{\circ} \mathrm{C}$, sob agitação a $120 \mathrm{rpm}$. Os plasmídeos foram extraídos utilizando o Kit PureLink Quick Plasmid Miniprep (Invitrogen). A concentração dos plasmídeos contendo os insertos $16 S$ rRNA de Archaea foi determinada pela medida de absorbância a 260 ๆm em espectrofotômetro (NanoDrop ND-1000, Nanodrop Technologies, Wilmington, Delaware, EUA). Posteriormente, a solução de DNA plasmidial foi diluída obtendo-se $10^{10}$ cópias $/ \mu \mathrm{L}$, a partir da qual foram realizadas diluições em série, variando de $10^{2}$ a $10^{8}$ cópias, e estas utilizadas como DNA molde em PCR em tempo real para a montagem da curva padrão.

\subsubsection{Condições Gerais para PCR em Tempo Real}

A análise quantitativa foi realizada através de PCR em tempo real utilizano o termociclador iQ 5 Bio-Rad (Bio Rad, Rio de Janeiro, Brasil) e os produtos foram 
detectados por fluorescência usando QuantiMix Easy SYG kit (Biotools, Madri, Espanha), seguindo o protocolo recomendado pelo fabricante. Para a reação foram utilizados $12,5 \mu \mathrm{L}$ de SYBR Green, 50-75 $\mu \mathrm{g}$ de DNA molde e 0,5 $\mu \mathrm{M}$ de cada iniciador descrito por Einen, Thorseth e Ovre (2008) em um volume final de $25 \mu \mathrm{L}$. Para a curva padrão foram realizadas reações contendo como DNA molde $10^{2}$ a $10^{8}$ cópias do gene analisado (16S rRNA de Archaea) utilizando-se dos plasmídeos obtidos conforme descrito no item 3.6.2.1 Estabelecimento dos Padrões. Como controle negativo foi adicionado água milliQ ao invés de DNA molde. As reações foram realizadas com pré-incubação a $95^{\circ} \mathrm{C}$ por 15 min, 45 ciclos de desnaturação a $94^{\circ} \mathrm{C}$ por $15 \mathrm{~s}$, anelamento a $64{ }^{\circ} \mathrm{C}$ por $30 \mathrm{~s}$ e extensão a $72{ }^{\circ} \mathrm{C}$ por $30 \mathrm{~s}$, seguidos por uma extensão final a $72{ }^{\circ} \mathrm{C}$ por $7 \mathrm{~min}$.

A fluorescência foi detectada após cada ciclo e representada em um gráfíco utilizando o software iQ5 Optical System (Bio-Rad). A leitura da placa foi feita a cada ciclo por $10 \mathrm{~s}$ a $72{ }^{\circ} \mathrm{C}$.

Todas as amostras foram analisadas em duplicata e cada diluição dos plasmídeos para a curva padrão em triplicata. A eficiência da reação variou de 85 a 105\% se

estabelecendo dentro do que é preconizado pelo fabricante do equipamento iQ 5 Bio-Rad (Bio-Rad).

\subsubsection{Análise da curva de dissociação}

Após a reação foi realizada a curva de dissociação para verificar a especificidade dos amplicons. Foram relaizados 30 ciclos de $60 \mathrm{~s}$ com queda de $1^{\circ} \mathrm{C}$ por ciclo iniciandose em $95^{\circ} \mathrm{C}$ até atingir a temperatura de $65^{\circ} \mathrm{C}$.

\subsubsection{Quantificação do Domínio Bacteria}

\subsubsection{Estabelecimento dos Padrões}

DNA de $P$. gingivalis W83 foi utilizado para estabelecer a curva padrão do domínio Bacteria. A região $16 S$ rRNA deste domínio foi amplificada utilizando os iniciadores universais modificados 9F 5'-GAGTTTGATYMTGGCTCAG-3' e 1525R 5'GAAGGAGGTGWTDCC-3', conforme descrito por Faveri et al. (2008). Para a reação de 
amplificação foram utilizados: $1 \mu \mathrm{L}$ de DNA molde, 2,5 U de Taq Polimerase Platinum (Invitrogen), $5 \mu \mathrm{L}$ de tampão de PCR (10X) (Invitrogen), 0,8 mM de cada dNTP (Invitrogen), $500 \eta \mathrm{M}$ de cada iniciador (Invitrogen), 1,5 mM de $\mathrm{MgCl}_{2}$ (Invitrogen) em um volume final de $50 \mu \mathrm{L}$. As reações foram realizadas com pré-incubação $94{ }^{\circ} \mathrm{C}$ por $4 \mathrm{~min}$, seguida de 30 ciclos de desnaturação a $94{ }^{\circ} \mathrm{C}$ por $45 \mathrm{~s}$, anelamento a $60{ }^{\circ} \mathrm{C}$ por $45 \mathrm{~s}$, extensão a $72{ }^{\circ} \mathrm{C}$ por $90 \mathrm{~s}$ e extensão final a $72{ }^{\circ} \mathrm{C}$ por 15 min em termociclador (Gen Amp PCR System 2400). Os amplicons foram clonados, purificados e quantificados como descrito 3.5.2.1 Estabelecimento dos Padrões para quantificação do domínio Archaea. Diluições seriadas dos plasmídeos contendo o inserto com $1500 \mathrm{pb}$ do gene $16 S$ rRNA de Bacteria foram usadas para construção da curva padrão.

\subsubsection{Condições Gerais para PCR em Tempo Real}

Para a quantificação do domínio Bacteria foi utilizado o par de iniciadores 381f 5'ACTCCTACGGGAGGCAGCAG-3` e 518r 5’ATTACCGCGGCTGCTGG-3’ descrito por Ovreas; Torsvik (1998), que resulta em um produto de 297 pb. As reações de amplificação foram conduzidas com 12,5 $\mu \mathrm{L}$ de SYBR Green, 50-75 $\mu \mathrm{g}$ de DNA molde e $0,5 \mu \mathrm{M}$ de cada iniciador, em um volume final de $25 \mu \mathrm{L}$. Para a curva padrão foram realizadas reações contendo como DNA molde $10^{2}$ a $10^{8}$ cópias do gene analisado (16S rRNA de Bacteria) utilizando-se dos plasmídeos obtidos conforme descrito no item 3.6.3.1 Estabelecimento dos Padrões para quantificação do domínio Bacteria. Como controle negativo foi adicionado água milliQ ao invés de DNA molde. As reações de amplificação foram constituídas de pré-incubação a $95{ }^{\circ} \mathrm{C}$ por $15 \mathrm{~min}, 45$ ciclos de desnaturação a $94{ }^{\circ} \mathrm{C}$ por $15 \mathrm{~s}$, anelamento a $61^{\circ} \mathrm{C}$ por $30 \mathrm{~s}$, extensão a $72{ }^{\circ} \mathrm{C}$ por $30 \mathrm{~s}$, leitura da placa a $72{ }^{\circ} \mathrm{C}$ por $10 \mathrm{~s}$ adicionais e extensão final a $72{ }^{\circ} \mathrm{C}$ por $7 \mathrm{~min}$.

A fluorescência foi detectada após cada ciclo e representada em um gráfico utilizando o software iQ5 Optical System (Bio-Rad). A leitura da placa foi feita a cada ciclo por $10 \mathrm{~s}$ a $72{ }^{\circ} \mathrm{C}$.

Todas as amostras foram analisadas em duplicata e cada diluição dos plasmídeos para a curva padrão em triplicata. A eficiência da reação variou de 85 a $105 \%$ se 
estabelecendo dentro do que é preconizado pelo fabricante do equipamento iQ 5 Bio-Rad (Bio-Rad).

\subsubsection{Análise da curva de dissociação}

Após a reação foi realizada a curva de dissociação para verificar a especificidade dos amplicons. Foram relaizados 30 ciclos de $60 \mathrm{~s}$ com queda de $1{ }^{\circ} \mathrm{C}$ por ciclo iniciandose em $95^{\circ} \mathrm{C}$ até atingir a temperatura de $65^{\circ} \mathrm{C}$.

\subsection{CÁlCULO DA PORCENTAGEM DE ARCHAEA EM RELAÇÃO AO TOTAL DE PROCARIONTES}

A percentual de cópias (proporção) do gene $16 S$ rRNA Archaea em relação ao total de procariontes em amostras de biofilme subgengival foi calculado dividindo o número absoluto do gene $16 \mathrm{~S}$ rRNA de Archaea de cada amostra pelo total de procariontes obtido pela soma das cópias do gene $16 S$ rRNA de Archaea e Bacteria na respectiva amostra. A proporção foi computada para cada sítio, e então entre os sítios de indivíduos de um mesmo grupo experimental.

\subsection{ANÁLISE ESTATÍSTICA}

\subsubsection{Análise Clínica}

A média de idade e dos parâmetros clínicos de profundidade de sondagem e nível clínico de inserção, assim com a média da porcentagem de sítios apresentando placa visível, sangramento gengival, sangramento à sondagem e supuração foram computadas para cada indivíduo e, posteriormente, dentro de cada grupo. As diferenças dentro de cada grupo foram avaliadas utilizando o teste $U$ de Mann-Whitney. A diferença na distribuição do gênero foi avaliada utilizando o teste Qui-quadrado. A significância estatística foi estabelecida em $5 \%$. 


\subsubsection{Análise Microbiológica}

O teste do Qui-quadrado foi usado para analisar se a prevalência de Archaea difere entre os grupos PA e SP, assim como se houve diferença significante no número de sítios positivos para Archaea entre as 3 categorias de profundidade de sondagem.

O teste U de Mann-Whitney foi utilizado para determinar diferenças nos níveis de Archaea, determinados pelo PCR quantitativo, entre sítios do grupo PA e SP, entre sítios com $\mathrm{PS} \leq 3 \mathrm{~mm}$ e $\mathrm{PS} \geq 7 \mathrm{~mm}$ do grupo PA e entre os sítios com $\mathrm{PS} \leq 3 \mathrm{~mm}$ do grupo PA e do grupo SP. A significância estatística foi estabelecida em 5\%. 


\section{RESULTADOS}

\subsection{Achados Clínicos}

As características demográficas e clínicas dos indivíduos envolvidos neste estudo, diagnosticados como pertencentes aos grupos com saúde periodontal ou com periodontite agressiva generalizada estão apresentadas na Tabela 2. A média de idade e a distribuição dos indivíduos quanto ao gênero foram semelhantes entre os dois grupos. Os valores médios de profundidade de sondagem e nível clínico de inserção e o percentual de sangramento à sondagem, medidas de gravidade de doença, foram significantemente maiores no grupo PA do que no grupo com periodonto saudável, cujos valores se apresentaram dentro dos padrões estabelecidos para caracterizar a saúde periodontal.

Tabela 2- Média $( \pm \mathrm{DP})$ dos parâmetros demográficos e clínicos para os indivíduos com saúde periodontal e periodontite agressiva generalizada.

\begin{tabular}{lcc}
\hline \multicolumn{1}{c}{ Variáveis } & SP & PA \\
Idade & $n=30$ & $n=30$ \\
Gênero (F/M) & $17 / 13$ & $16 / 14$ \\
Profundidade de sondagem * & $24,5 \pm 5,1(20-28)$ & $26,2 \pm 4,1(20-29)$ \\
Nível clínico de inserção * & $2,28 \pm 0,59$ & $4,36 \pm 0,88$ \\
\% sítios & $2,39 \pm 0,35$ & $4,41 \pm 1,27$ \\
Índice de placa visível* & & \\
Índice de sangramento gengival & $26,91 \pm 10,49$ & $48,79 \pm 11,91$ \\
Sangramento à sondagem * & $7,91 \pm 5,48$ & $11,49 \pm 11,22$ \\
Supuração * & $10,31 \pm 9,25$ & $72,30 \pm 23,05$ \\
\hline \hline
\end{tabular}

* Teste $U$ Mann-Whitney; $\mathrm{p}<0,05$

SP: Saúde Periodontal ; PA: Periodontite agressiva; F: Feminino; M: Masculino.

\subsection{SELEÇÃO DOS INICIADORES UNIVERSAIS}

Para a seleção dos iniciadores a serem utilizados na detecção de Archaea por PCR convencional e na estimativa da diversidade do domínio em amostras subgengivais foram empregandos dois pares de iniciadores Archaea-específicos (KULIK et al., 2001; LEPP et al., 2004), usando como molde o DNA obtido de amostras de 1 sítio profundo (AMOSTRA A) e 1 raso (AMOSTRA B) de um mesmo indivíduo com periodontite agressiva. A Figura 
1 apresenta os produtos da reação de amplificação do gene $16 S$ rRNA para cada par de iniciadores avaliados neste estudo.

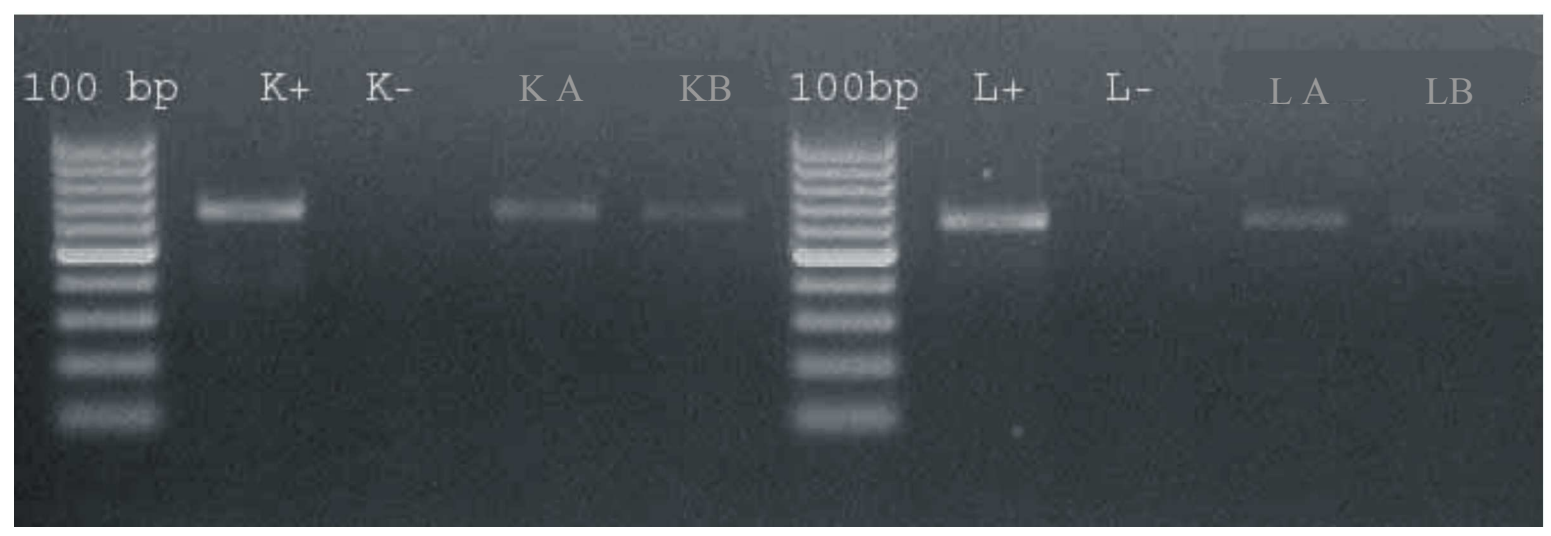

Figura 1. Fotografia do gel de agarose (1,5\%) corado com brometo de etídio em tampão TAE (1X) onde foram submetidos à eletroforese os produtos das reações de amplificação utilizando os iniciadores listados na Tabela 1. (K) par de iniciadores descrito por KULIK et al. (2001) e (L) par de iniciadores descrito por LEPP et al. (2004); (A) DNA molde de um sítio profundo e (B) de um sítio raso de um mesmo indivíduo com periodontite agressiva. (+) Controle positivo e (-) Controle negativo. 100 bp: Peso Molecular 100 bp DNA Ladder (Fermentas).

Desta forma, foram clonados e seqüenciados com sucesso, em média 35 clones por amostra clínica para a construção da biblioteca genômica de cada par de iniciadores. Para identificação das espécies do domínio Archaea foram seqüenciados os primeiros 500 pb do gene $16 S r R N A$. Estas seqüências foram comparadas com o banco de genes (BLAST, Genbank).

A Figura 2 apresenta a árvore filogenética formada pela seqüência de 500-600 pb dos 74 clones analisados obtidos a partir do mesmo molde de DNA (AMOSTRA A) usando os dois pares de iniciadores universais. Utilizando os iniciadores preconizados por Kulik et al. (2001), foi observado que entre os 45 clones analisados, todos apresentavam uma similaridade de 99\% com a espécie Methanobrevibacter oralis. Os mesmos resultados foram observados nos 29 clones analisados quando utilizamos os iniciadores preconizados por Lepp et al. (2004). 


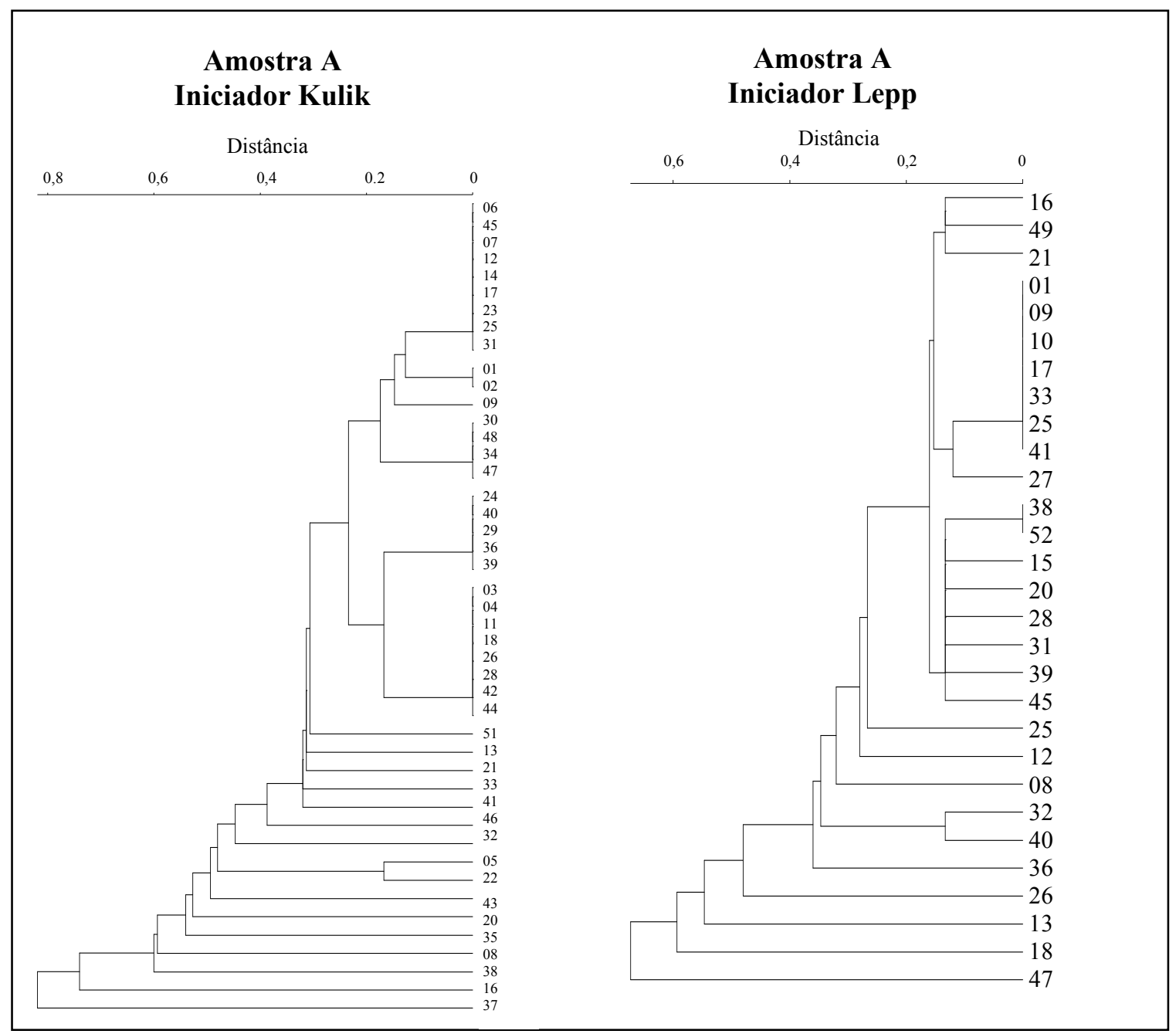

Figura 2. Árvore filogenética construída a partir da seqüência de 500-600 pb do gene $16 S$ rRNA das espécies detectadas a partir de bibliotecas genômicas obtidas usando como DNA molde uma amostra de biofilme subgengival de um sítio profundo (AMOSTRA A) de um indivíduo com periodontite agressiva, utilizando 2 pares de iniciadores diferentes para Archaea descritos por Kulik et al. (2001) e Lepp et al. (2004). A distância filogenética dos clones seqüenciados é dada em porcentagem de nucleotídeos substituídos após alinhamento e aproximação pelo método de Jukes e Cantor (1969), usando o programa Bionumerics.

A Figura 3 apresenta a árvore filogenética formada pela seqüência de 500-600 pb dos 76 clones analisados com sucesso usando como molde DNA da amostra B com ambos os pares de iniciadores. Utilizando o par de iniciadores preconizado por Kulik et al. (2001), observamos que dos 43 clones analisados, todos apresentavam similaridade de 99\% com a espécie M. oralis. Os mesmos resultados foram observados nos 33 clones analisados quando utilizamos o par de iniciadores descrito por Lepp et al. (2004). 


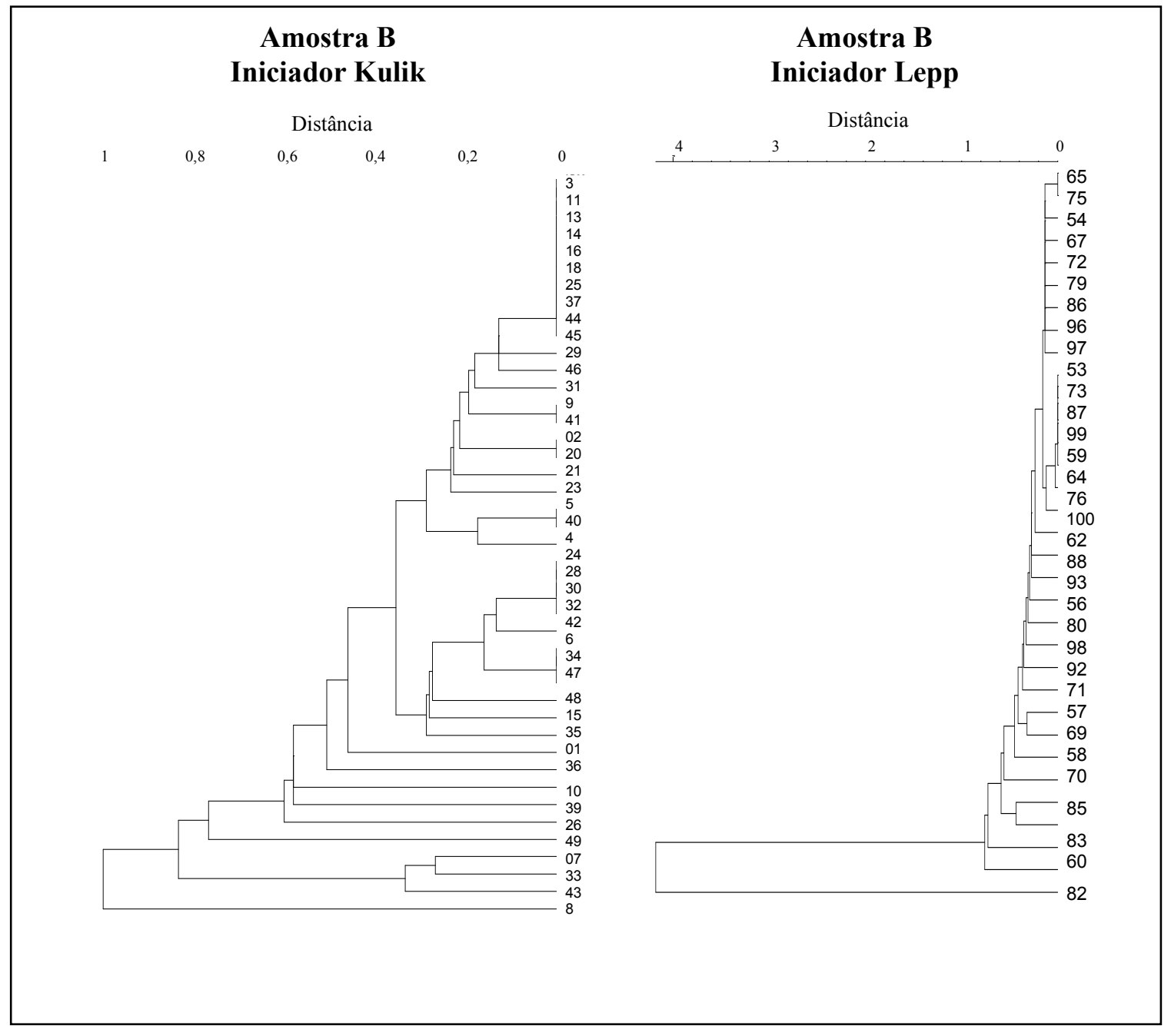

Figura 3. Árvore filogenética construída a partir da seqüência de $500-600 \mathrm{pb}$ do gene $16 S \mathrm{rRNA}$ das espécies detectadas a partir de bibliotecas genômicas obtidas usando como DNA molde uma amostra de biofilme subgengival de um sítio raso (AMOSTRA B) de um indivíduo com periodontite agressiva, utilizando 2 pares de iniciadores diferentes para Archaea descritos por Kulik et al. (2001) e Lepp et al. (2004). A distância filogenética dos clones seqüenciados é dada em porcentagem de nucleotídeos substituídos após alinhamento e aproximação pelo método de Jukes e Cantor (1969), usando o programa Bionumerics.

Frente aos resultados em que somente a espécie $M$. oralis foi detectada em ambas as amostras, optou-se pelo par de inciadores proposto por Kulik et al. (2001), pois a reação com o iniciador selecionado gerou bandas mais evidentes. É evidente também que este par de iniciadores amplifica uma região de $16 S$ rRNA mais conservada dentro da espécie. 


\subsection{PREVALÊNCIA DE ARCHAEA}

A prevalência do domínio Archaea foi determinada em 540 amostras de biofilme subgengival obtidas de 60 indivíduos ( $n=30$ /grupo), por PCR convencional, tendo como alvo o gene $16 S$ rRNA. Os dados de detecção de Archaea por indivíduo e por sítio em cada grupo em estudo, saúde periodontal e periodontite agressiva, estão apresentados na Tabela 3.

Tabela 3- Prevalência do domínio Archaea em amostras obtidas de indivíduos com saúde periodontal e periodontite agressiva por PCR convencional.

\begin{tabular}{lcc}
\hline \hline \multicolumn{1}{c}{ Grupo } & $\begin{array}{c}\text { Número indivíduos } \\
\text { positivos/total indivíduos }\end{array}$ & $\begin{array}{c}\text { Número de sítios } \\
\text { positivos/total sítios }\end{array}$ \\
Saúde Periodontal & $19(63,3 \%) / 30$ & $42(15,6 \%) / 270$ \\
Periodontite Agressiva & $18(60 \%) / 30$ & $41(15,2 \%) / 270$ \\
\hline \hline
\end{tabular}

p>0,05: Não houve diferença estatisticamente significante (Teste Qui-quadrado)

Não foi observada diferença estatisticamente significante na prevalência de Archaea por indivíduo ou por número de sítios positivos entre os grupos.

Um total de 270 amostras de biofilme subgengival foram coletadas de indivíduos do grupo PA, 90 obtidas de cada categoria de PS rasa, moderada e profunda. A Figura 4 apresenta a distribuição de sítios positivos para Archaea em nas diferentes profundidades de sondagem analisadas. Apesar da freqüência de detecção de Archaea ter sido mais baixa entre os sítios rasos (19,5\%), quantos estes foram comparados com os sítios moderados (46,3\%) e profundos (34,2\%), não houve diferença significante na prevalência de Archaea, e nenhuma associação entre o aumento na PS e a presença de Archaea foi estabelecida em indivíduos com periodontite agressiva. 


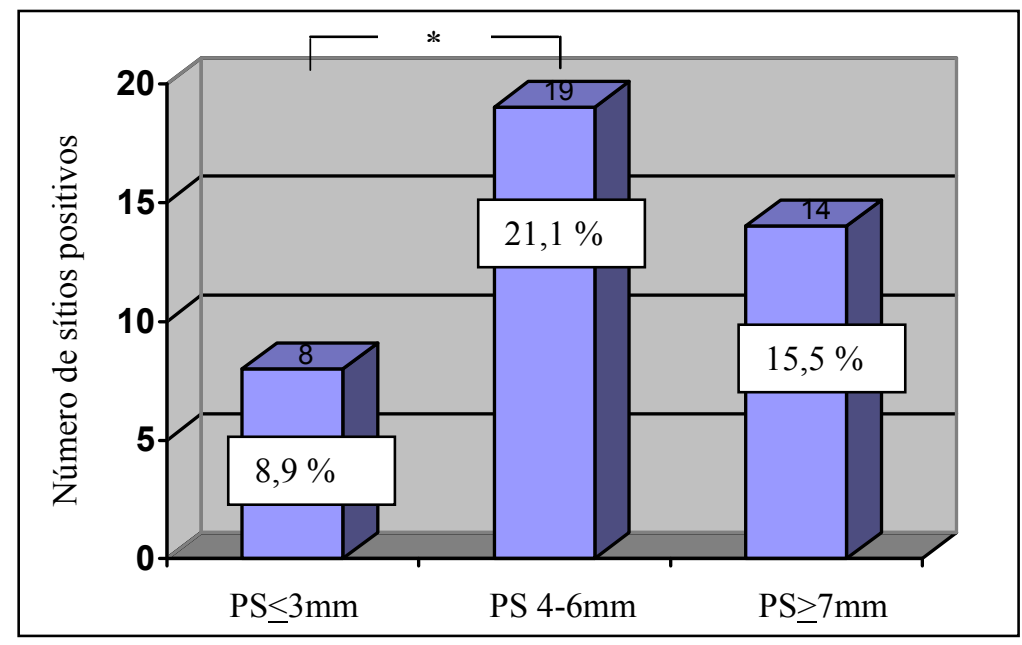

Figura 4. Distribuição de sítios com Archaea detectável nas diferentes categorias de profundidade de sondagem (PS) analisadas no grupo com periodontite agressiva. Diferença estatisticamente significante entre as categorias de PS (Teste Kruskal-Wallis, ${ }^{*} p<0,05$ ).

Quando se analisa a distribuição de sítios positivos e negativos para Archaea de indivíduos do grupo PA em relação ao total analisado nas categorias de sítios sem perda de inserção (PS $\leq 3 \mathrm{~mm}$ ) e com destruição do aparato de inserção (PS $\geq 4 \mathrm{~mm}$ ), nota-se que a prevalência de Archaea nos sítios moderados e profundos é significantemente maior do que nos sítios rasos.

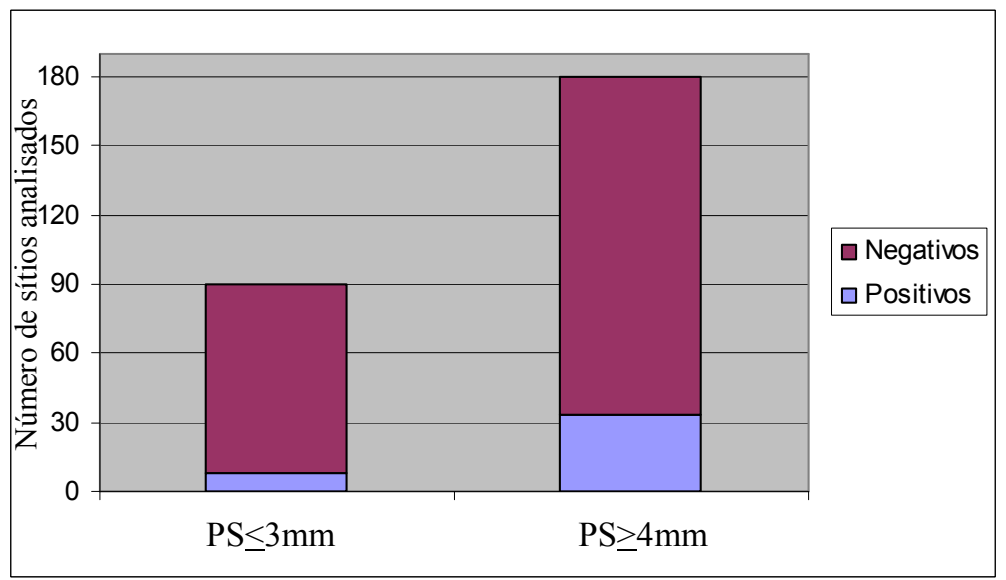

Figura 5. Distribuição de sítios positivos e negativos para Archaea no grupo com periodontite agressiva, em sítios com profundidade de sondagem (PS) rasa (PS $\leq 3 \mathrm{~mm}$ ) e $\mathrm{PS} \geq 4 \mathrm{~mm}$. Diferença estatisticamente significante entre as categorias de PS (Teste Qui-quadrado, * $p<0,05)$. 


\subsection{DIVERSIDADE DE ARCHAEA}

A identidade filogenética de 629 clones foi determinada pelo sequenciamento de 400 a $600 \mathrm{pb}$ do inserto por clone. O número de clones $16 S$ rRNA disponíveis para a identificação variou de 33 a 47 no grupo PA, e de 15 a 23 no grupo SP, com uma média de $42,8 \pm 3,9$ e 20,1+2,2, respectivamente. Um nível de $99 \%$ de similaridade entre as sequências foi utilizado como ponto de corte para a identificação de um táxon específico (PASTER et al., 2001; ACHTMAN; WAGNER, 2008; KEMP; ALLER, 2008). Três diferentes gêneros de Archaea metanogênicos foram identificados nos dois grupos clínicos: Methanobrevibacter, Methanobacterium e Methanosarcina (Figura 6). Methanobrevibacter oralis, o filotipo mais prevalente, foi detectado em todas as amostras analisadas, representando $82 \%$ dos clones identificados no grupo PA, e 70,1\% no grupo SP. A identidade das espécies não pôde ser determinada para os filotipos classificados como Methanobacterium curvum/congolense AF276958/AF233586 já que estes compartilham homologia maior que $99 \%$ na seqüência do gene $16 S r R N A$. O filotipo $M$. curvum/congolense incluiu 7,2\% e 17,9\% dos clones analizados no grupo PA e SP, respectivamente. A espécie Methanosarcina mazeii representou 10,8\% dos clones seqüenciados no grupo PA e $12 \%$ dos clones seqüenciados para o grupo SP.

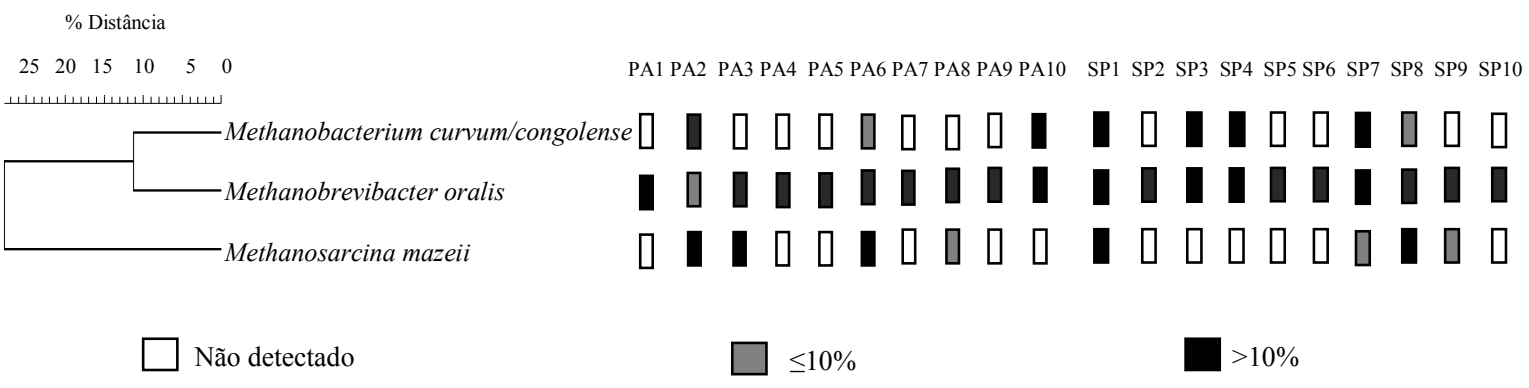

Figura 6. Árvore filogenética baseada nas seqüências do gene $16 S$ rRNA (GENBANK) das espécies de Archaea metanogênicas identificadas em amostras de biofilme subgengival obtidas de 10 indivíduos com periodontite agressiva generalizada (PA) e de 10 indivíduos com saúde periodontal (SP). A distância filogenética dos clones seqüenciados é dada em porcentagem de nucleotídeos substituídos após alinhamento e aproximação pelo método de Jukes e Cantor (1969), usando o programa Bionumerics.

A Figura 7 apresenta a distribuição de clones identificados como M. oralis, $M$. curvum/congolense e M. mazeii em amostras obtidas de indivíduos do grupo com saúde 
periodontal e periodontite agressiva. Na saúde periodontal três dos 10 indivíduos analisados apresentavam apenas o filotipo M. oralis (Figura 7A). Em outras três amostras do mesmo grupo de indivíduos foram identificados predominantemente filotipos $M$. curvum/congolense e M. mazeii. Observa-se que em 5 amostras de indivíduos com periodontite agressiva, $M$. oralis foi o único filotipo identificado, e que em apenas duas amostras os filotipos M. curvum/congolense e M. mazeii representaram mais de $50 \%$ dos clones identificados.
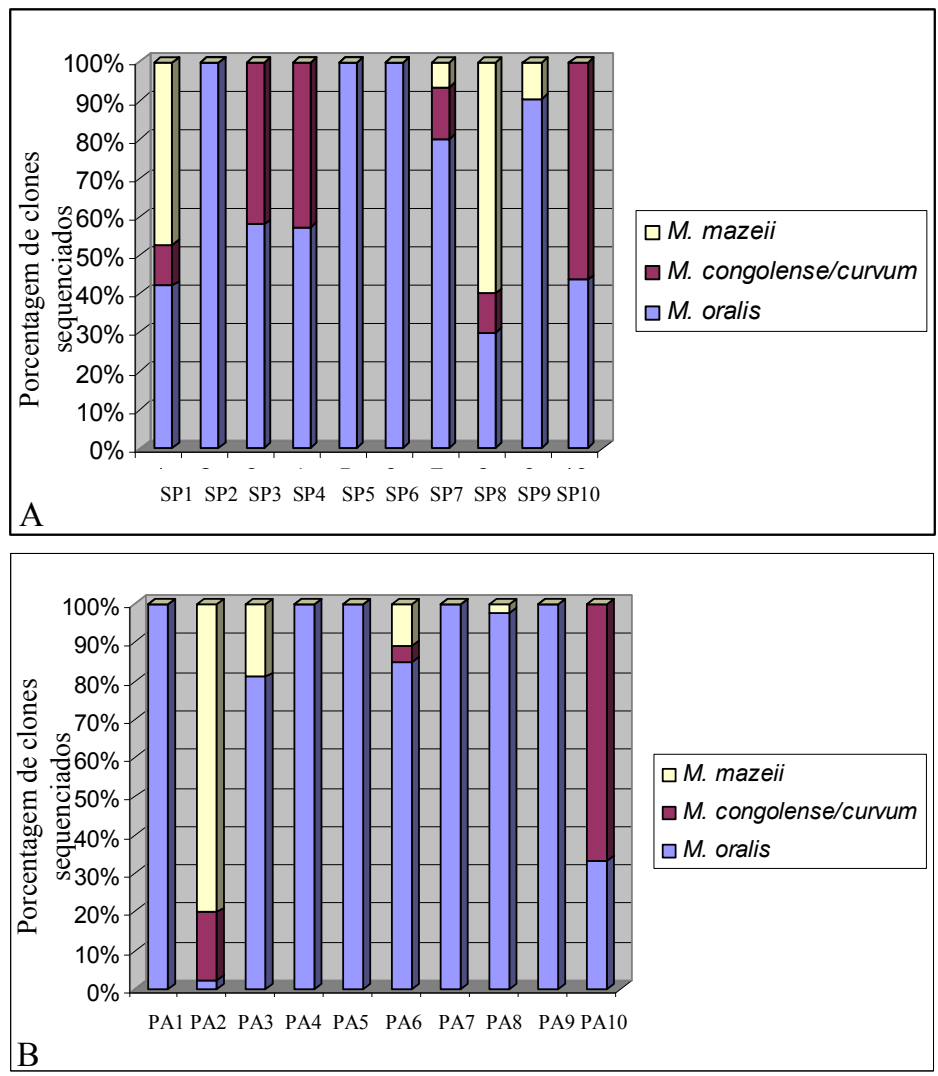

Figura 7. Porcentagem do número de clones identificados como Methanobrevibacter oralis, Methanobacterium curvum/congolense e Methanosarcina mazeii em amostras de biofilme subgengival de indivíduos com saúde periodontal (A) e periodontite agressiva generalizada $(\mathrm{P})$.

\subsubsection{Análise de Rarefação e Índice de Cobertura}

A Figura 8 apresenta as curvas de rarefação para a diversidade de Archaea em amostras obtidas de 10 indivíduos do grupo SP (A) e PA (B). O formato curvilíneo do traçado nas diferentes amostras, tanto provenientes de indivíduos com doença periodontal, 
quanto de indivíduos periodontalmente saudáveis demonstra que as bibliotecas foram dominadas por poucos filotipos abundantes. Além disso, as curvas de rarefação obtidas no grupo com saúde periodontal (Figura 8A) são nitidamente mais acentuadas do que as curvas que se originaram da análise de rarefação das amostras do grupo com periodontite agressiva generalizada (Figura 8B), mesmo com uma menor quantidade de clones seqüenciados por amostra, demonstrando que a diversidade observada não foi influenciada pela diferença no número de clones analisados por amostra.
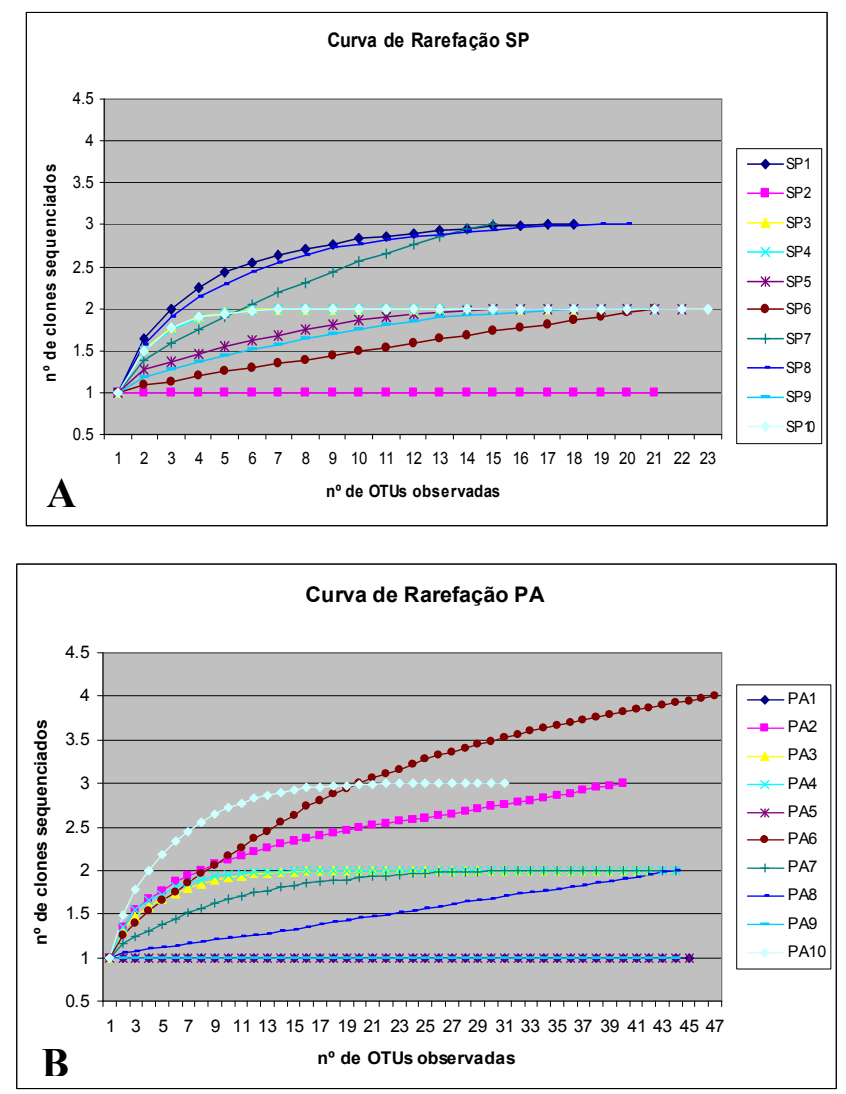

Figura 8. Curvas de rarefação da diversidade de Archaea em amostras obtidas de 10 indivíduos com saúde periodontal (SP, A) e com periodontite agressiva generalizada (PA, B), usando o programa DOTUR.

Sete entre as dez bibliotecas de Archaea geradas a partir de amostras obtidas de indivíduos com periodontite agressiva generalizada não apresentaram filotipos raros (aqueles que ocorrem uma única vez). Entre as amostras obtidas de indivíduos periodontalmente saudáveis, oito de dez bibliotecas de Archaea não apresentaram filotipos ocorrendo apenas uma vez. Assim, o índice de cobertura das bibliotecas foi estabelecido 
em $99 \pm 1 \%$ nas amostras do grupo com periodontite agressiva e em $99 \pm 2 \%$ nas de indivíduos com saúde periodontal.

\subsection{QUANTIFICAÇÃO DE ARCHAEA E BACTERIA}

A análise quantitativa foi realizada em 2 sítios $\operatorname{rasos}(\mathrm{PS} \leq 3 \mathrm{~mm})$ e 2 sítios profundos (PS $\geq 5 \mathrm{~mm}$ ) de 30 indivíduos do grupo PA e em 2 sítios de indivíduos do grupo SP. No entanto, 2 indivíduos/17 sítios foram excluídos, pois houve degradação do DNA, detectado pela ausência de resultados quando o domínio Bacteria foi analisado. Sendo assim, foram anotados os resultados obtidos a partir de amostras obtidas de 28 indivíduos/103 sítios do grupo PA, e de 30 indivíduos/60 sítios do grupo SP. Apenas um indivíduo do grupo PA e quatro indivíduos do grupo SP foram negativos para Archaea nos ensaios de PCR em tempo real. A análise por sítio revelou a presença de Archaea em 68\% e 58,3\% dos sítios analisados nos grupos PA e SP, respectivamente, sem diferença estatísticamente significante entre eles (Tabela 4).

Tabela 4- Prevalência do domínio Archaea em amostras obtidas de indivíduos com saúde periodontal e periodontite agressiva por PCR quantitativo.

\footnotetext{
periodontal e periodontite agressiva por PCR quantitativo.

Grupo

Número indivíduos

Número de sítios

positivos/total indivíduos

positivos/total sítios

Saúde Periodontal

$26(86,7 \%) / 30$

$35(58,3 \%) / 60$

Periodontite Agressiva

$27(96,4 \%) / 28$

$70(68 \%) / 103$

p>0,05: Não houve diferença estatisticamente significante (Teste Qui-quadrado)

Quando se comparou a frequência de detecção de Archaea em relação ao total de sítios analisados por categoria de profundidade de sondagem observou-se que a freqüência de detecção entre os sítios rasos de indivíduos com periodontite agressiva foi não diferiu estatisticamente da frequência de detecção entre os sítios profundos dos mesmos indivíduos (Figura 9). Também não houve diferença na prevalência de Archaea entre os sítios dos indivíduos do grupo saúde periodontal e os sítios do grupo periodontite agressiva, independente da categoria de profundidade de sondagem.
} 


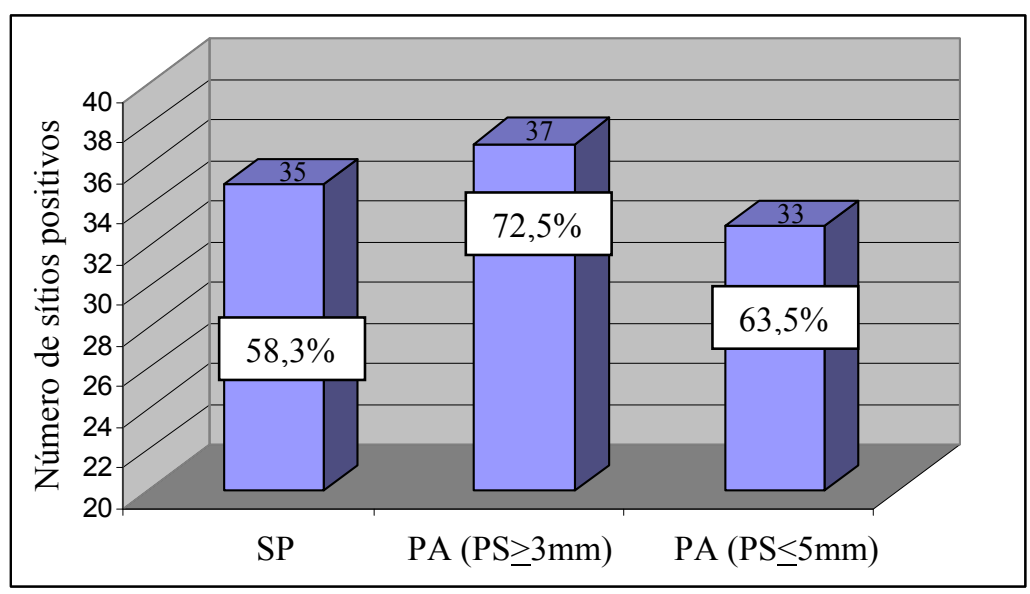

Figura 9. Distribuição e percentual de sítios com Archaea detectável em relação ao total de sítios analisados no grupo com saúde periodontal (SP) e nas categorias de sítios rasos $(\mathrm{PS} \leq 3 \mathrm{~mm}$ ) e profundos (PS $\geq 5 \mathrm{~mm}$ ) no grupo com periodontite agressiva generalizada. Não houve diferença estatisticamente significante entre as categorias analisadas (Teste Kruskal-Wallis, $\mathrm{p}>0,05)$.

A Figura 10 apresenta as médias de contagem de número de cópias do gene $16 \mathrm{~S}$ rRNA dos domínios Archaea e Bacteria, em amostras dos indivíduos do grupo SP e PA. O nível médio ( \pm erro médio da medida) de Archaea nas amostras do grupo SP foi de 0,6 x $10^{4} \pm 0,2$ e no grupo PA de $11,2 \times 10^{4} \pm 6,6(\mathrm{p}<0,05)$, com diferença estatisticamente significante entre os grupos. $O$ valor médio de contagem ( \pm erro médio da medida) de Bacteria no grupo SP também foi estatisticamente inferior ao valor médio de contagem do grupo PA, representando $6,1 \times 10^{7} \pm 1,7$ e $11,5 \times 10^{7} \pm 2,3(\mathrm{p}<0,05)$, respectivamente. 


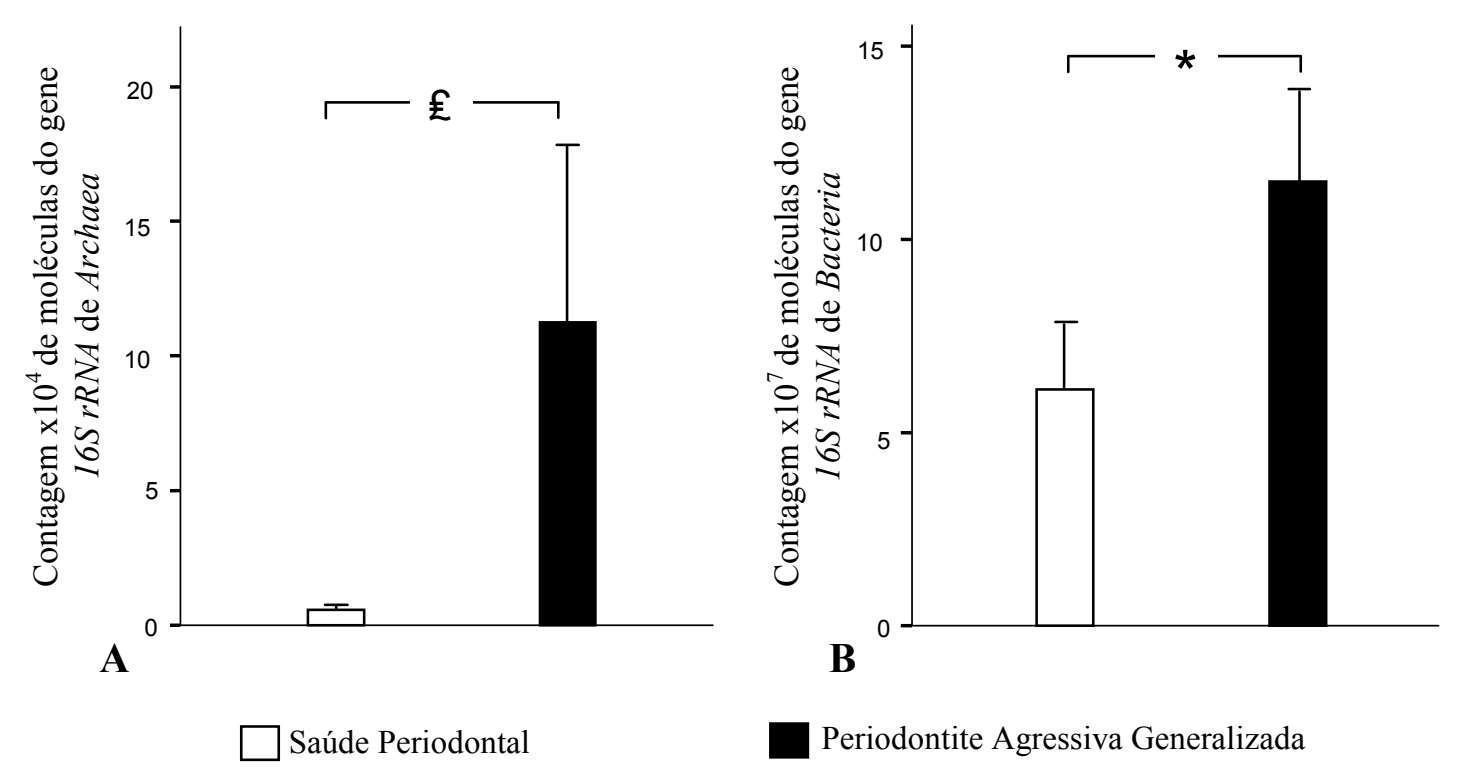

Figura 10. Média do número de cópias do gene $16 S r R N A$ de Archaea (x10 \pm EMM, A) e média de número de cópias do gene $16 S$ rRNA de Bacteria (x107 \pm EMM, B) em amostras obtidas de indivíduos com saúde periodontal e periodontite agressiva. Teste U MannWhitney, ${ }^{*} p<0,05$; £ $p<0,01$.

Quando a média do número de cópias ( \pm erro médio da medida) do gene $16 S$ rRNA de Archaea foi analisada considerando-se a categoria de PS de indivíduos com periodontite agressiva foi possível observar que as amostras obtidas de sítios com PS $\geq 5 \mathrm{~mm}$ apresentaram uma maior quantidade de Archaea $\left(12,5 \times 10^{4} \pm 5,1\right)$ do que as amostras obtidas de sítios sem perda de inserção (PS $\left.\leq 3 \mathrm{~mm}, 10,7 \times 10^{4} \pm 9,5\right)$. No entanto, não houve diferença estatisticamente significante entre as categorias estudadas dentro deste grupo. Quando o grupo com periodonto saudável foi considerado, os menores valores médios de contagem do gene $16 S \mathrm{rRNA}$ de Archaea foram encontrados $\left(0,6 \times 10^{4} \pm 0,2\right)$. Foi determinada diferença significante entre o número de cópias de Archaea nos sítios de indivíduos com periodonto saudável e sítios profundos daqueles com periodontite agressiva, mas não entre amostras dos sítios rasos dos grupos com saúde ou doença periodontal (Figura 11A).

Os níveis médios ( \pm erro médio da medida) de Bacteria nos sítios profundos de indivíduos com doença periodontal foram de $16 \times 10^{7} \pm 3,5$, nos sítios rasos destes mesmos indivíduos $7,8 \times 10^{7} \pm 1,8$ e nos sítios rasos de indivíduos com saúde periodontal de $6,1 \times$ $10^{7} \pm 1,8$ (Figura 11B). Os níveis médios de moléculas do gene $16 S r R N A$ bacteriano foram 
significativamente maiores em amostras obtidas de sítios profundos do que em amostras de sítios rasos de indivíduos com periodontite agressiva e do que de sítios rasos de indivíduos com saúde periodontal. O número de cópias de $16 \mathrm{~S}$ rRNA de Bacteria em amostras do grupo SP foi ligeiramente menor que o número de cópias do gene alvo nos sítios rasos de indivíduos com periodontite agressiva, mas esta diferença não foi estatisticamente significante $(\mathrm{p}>0,05)$.

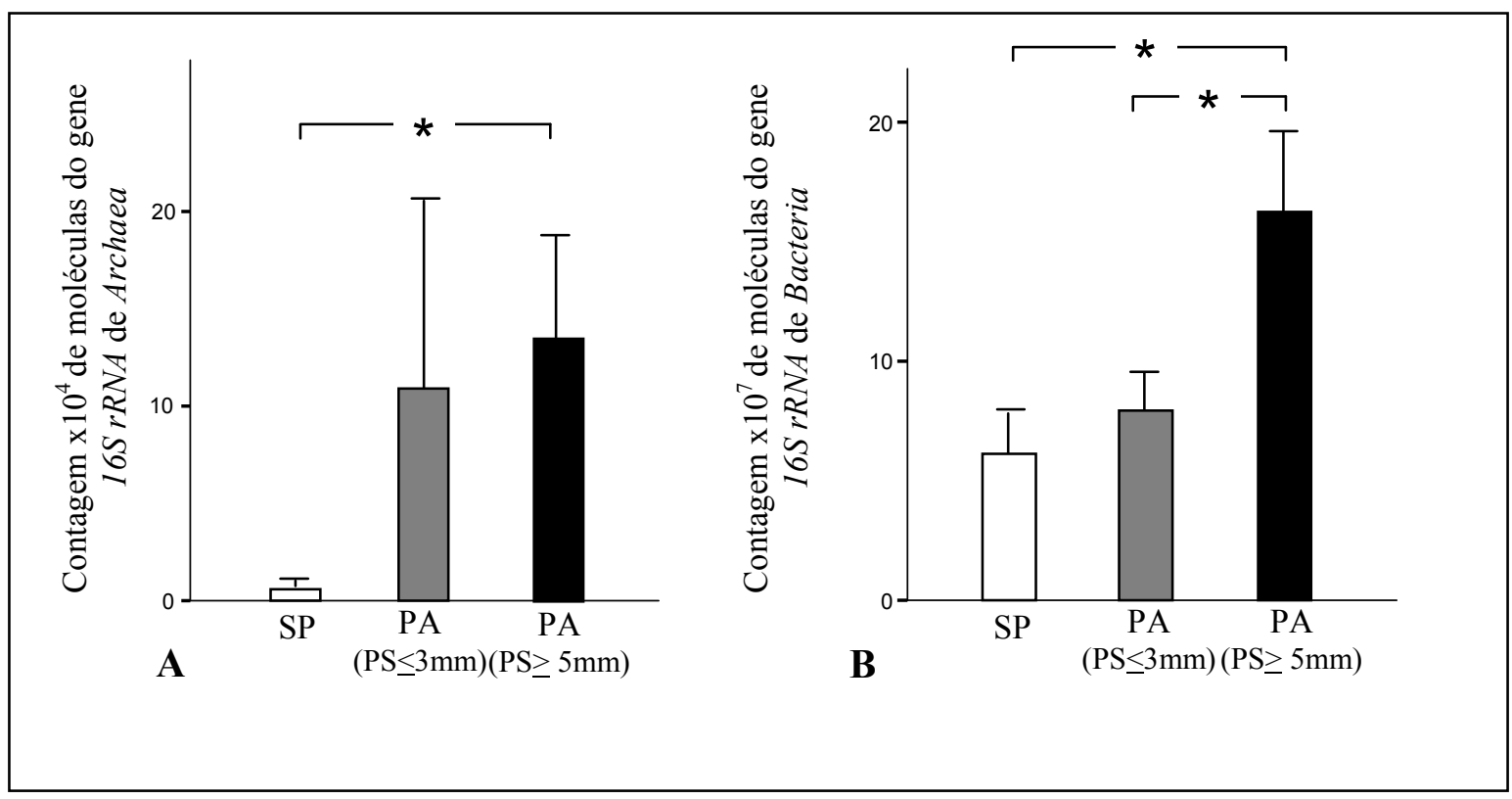

Figura 11. Média do número de cópias do gene $16 S r R N A$ de Archaea (x10 \pm EMM) e Bacteria $\left(\mathrm{x} 10^{7} \pm \mathrm{EMM}\right)$ em amostras obtidas de sítios rasos de indivíduos do grupo SP e de sítios rasos e profundos dos indivíduos do grupo PA. Teste U Mann-Withney, * $p<0,05$.

Os dados de proporção de microrganismos do domínio Archaea e Bacteria em relação ao total de procariontes no ambiente subgengival de indivíduos com saúde periodontal e periodontite agressiva estão apresentados na Tabela 5 e na Figura 12. 
Tabela 5- Proporção de Archaea e Bacteria em relação ao total de procariontes.

\begin{tabular}{lccc}
\hline \hline & & & \\
& & Grupo & \\
& Saúde Periodontal & Periodontite Agressiva Generalizada & Valor $\mathrm{p}$ \\
Archaea & $0,02 \%$ & $0,08 \%$ & 0,04 \\
Bacteria & $99,98 \%$ & $99,92 \%$ & \\
\hline \hline
\end{tabular}

Teste U Mann-Whitney.

Quando a proporção dos domínios foi analisada em cada categoria de profundidade de sondagem no grupo PA, a proporção de Archaea em relação à carga microbiana total foi ligeiramente maior em sítios rasos $(0,12 \%)$ que em sítios com PS $\geq 5 \mathrm{~mm}(0,08 \%)$, porém esta diferença não foi estatisticamente significante. Apesar de ter sido demonstrada maior proporção de Archaea em sítios de indivíduos PA em relação ao grupo SP (Tabela 5) não foi detectada diferença estatisticamente significante na proporção de Archaea entre os sítios sem perda de inserção de indivíduos do grupo SP e PA ou entre os sítios rasos e profundos de indivíduos do grupo PA (Figura 12). 


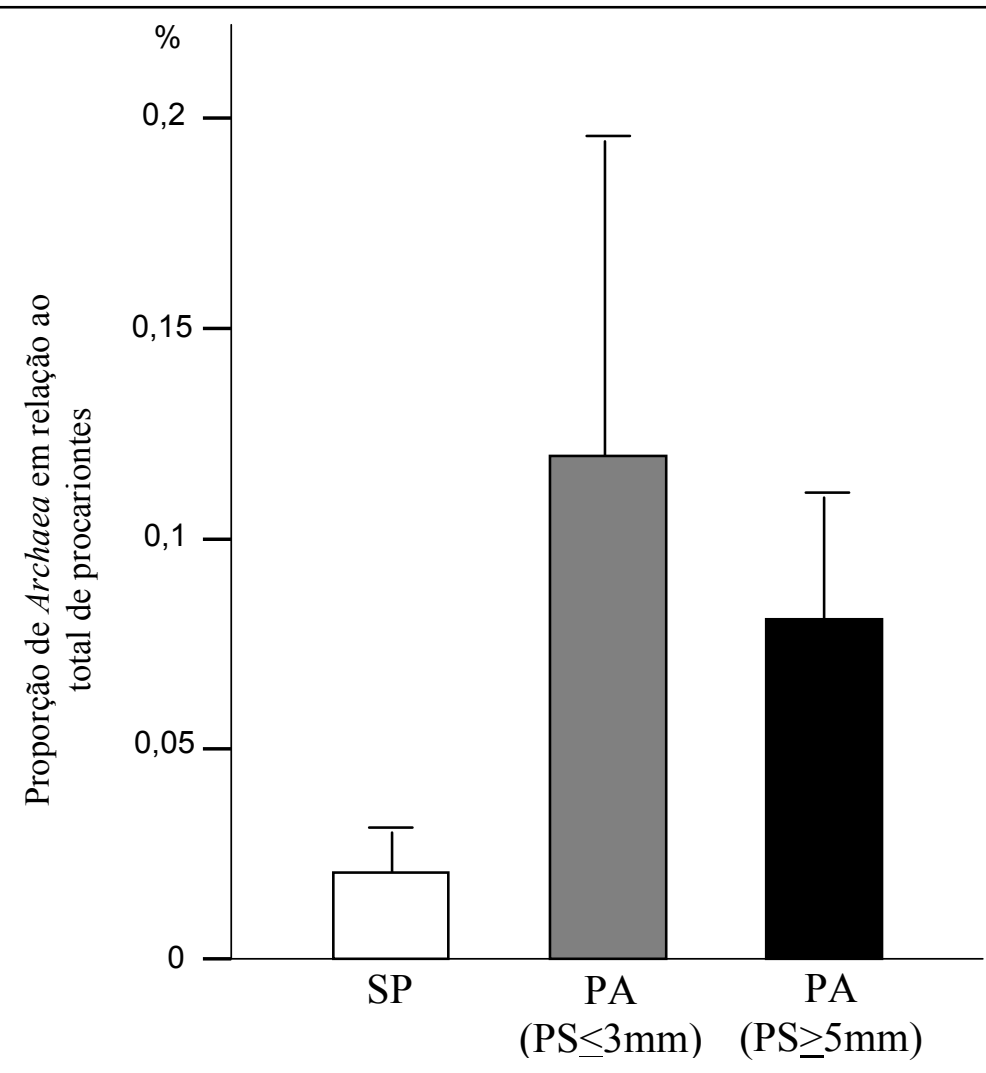

Figura 12. Média de proporção de microrganismos do domínio Archaea em relação ao total de procariontes (Archaea + Bacteria) em amostras de indivíduos com saúde periodontal e periodontite agressiva generalizada. $\mathrm{O}$ grupo com periodontite agressiva generalizada foi subdividido por categoria de profundidade de sondagem (PS) em sítios rasos (PS $\leq 3 \mathrm{~mm}$ ) e profundos (PS $\geq 5 \mathrm{~mm}$ ). Teste U Mann-Withney, $p>0,05$. 


\section{DISCUSSÃO}

Microrganismos do domínio Archaea não foram ainda reconhecidos como verdadeiros patógenos de doença humana (CAVICHIOLLI et al., 2003; ECKBURG; LEPP; RELMAN, 2003, CONWAY DE MACARIO; MACARIO, 2008). Este estudo teve como objetivo contribuir com o conhecimento sobre o papel de microrganismos do domínio Archaea no ecossistema subgengival, visando estabelecer se a detecção, diversidade, níveis e proporções destes organismos estão associados com a periodontite agressiva generalizada.

Estudos prévios indicaram que o domínio Archaea é frequentemente detectado em sítios com grande destruição periodontal, sugerindo sua relação com patogenia da periodontite (BELAY et al., 1988; KULIK et al. 2001; LEPP et al., 2004; YAMABE et al., 2008; VIANNA et al., 2008; LI et al., 2009). No entanto, estes dados diferem do presente estudo, pois até o momento, não havia sido relatada a deteç̧ão de Archaea em sítios subgengivais de indivíduos com saúde periodontal.

Trinta indivíduos caracterizados como portadores de doença periodontal agressiva generalizada e 30 indivíduos com periodonto saudável foram incluídos neste estudo. Para a análise de prevalência e diversidade do domínio Archaea no ambiente subgengival foram testados dois pares de iniciadores domínio-específicos usados previamente para análise de infecções periodontais (KULIK et al., 2001; LEPP et al., 2004). Um estudo recente mostrou não haver diferença na freqüência de deteç̧ão de Archaea utilizando os dois pares de iniciadores testados (LI et al., 2009). No presente estudo, a biblioteca genômica obtida com cada par de iniciadores (Figuras 2 e 3) também foi semelhante e todas as seqüências pertenciam ao mesmo filotipo. Assim, foi escolhido o par de iniciadores descrito por Kulik et al. (2001), que proporcionava bandas mais evidentes no gel, e amplificava uma região com menor variabilidade em $16 S$ rRNA de Methanobrevibacter oralis, o que sugere ser esta mais conservada dentro da espécie, facilitando a identificação.

Os dados de prevalência de Archaea diferiram quando foi empregado PCR convencional e PCR quantitativo, sendo esta última técnica mais sensível. A freqüência de detecção de Archaea em indivíduos com periodontite agressiva foi de $60 \%$ por PCR convencional (Tabela 3) de 96,4\% por PCR quantitivo (Tabela 4). A alta freqüência de Archaea com ambas as técnicas coincide com os valores apresentados em estudos prévios 
que utilizaram o mesmo par de iniciadores para o gene $16 S$ rRNA de Archaea que o ensaio em PCR convencional, nos quais Archaea foi detectado em 77\% dos indivíduos, com diferentes tipos de doença periodontal, incluindo periodontite crônica e agressiva (KULIK et al., 2001) e em 73,5\% dos indivíduos com periodontite crônica (LI et al., 2009).

No entanto, a frequência de detecção de Archaea por indivíduo apresentada aqui é consideravelmente maior do que em estudos que empregaram outro par de iniciadores domínio-específico, cujas frequências de indivíduos positivos variaram de 22,4 a 36\% dos indivíduos com comprometimento periodontal, por PCR convencional e quantitativo, respectivamente (LEPP et al. 2004; YAMABE et al. 2008). Como Li et al. (2009) afirmaram que ambos pares de iniciadores geraram reações positivas com a mesma freqüência, outros aspectos devem ser responsabilizados por estas diferenças. Utilizando iniciadores para o gene $m c r A$, Vianna et al. (2008) relataram uma prevalência de $43,1 \%$ dos indivíduos com sinais clínicos de destruição periodontal, frequência intermediária aos estudos que optaram por usar como alvo a subunidade menor do RNA ribossômico.

Quando a análise da presença de Archaea foi realizada por sítio, o gene $16 \mathrm{~S} r R N A$ de Archaea foi detectado por PCR convencional em 15,2\% dos sítios dos indivíduos com periodontite agressiva generalizada (Tabela 3), e em $68 \%$ dos sítios por PCR quantitativo (Tabela 4). Os dados de deteç̧ão por PCR convencional se assemelham aos dados encontrados na literatura (YAMABE et al., 2008), em que Archaea foi detectado em 17,4\% dos sítios de 17 indivíduos com periodontite agressiva. Quanto aos dados referentes a metodologia de PCR quantitativo, apesar do estudo de LEPP et al. (2004) não ter considerado os sítios rasos sem sangramento à sondagem na apresentação dos dados de prevalência por sítio, a detecção observada por eles $(76,6 \%)$ foi próxima ao relatado no presente estudo.

Vários estudos sugerem que os sítios subgengivais com maior profundidade de sondagem em indivíduos com periodontite são os principais responsáveis pela freqüência de detecção de Archaea (LEPP et al., 2004; YAMABE et al., 2008; LI et al., 2009). No presente estudo, embora os sítios com profundidade de sondagem moderada e profunda tenham apresentado maior prevalência de Archaea do que os sítios rasos (Figura 4), somente houve diferença na freqüência de detecção de Archaea entre sítios moderados e rasos, mas não entre profundos e rasos. No entanto, quando os sítios com PS $\geq 4 \mathrm{~mm}$ foram 
agrupados, a prevalência de Archaea foi maior do que a observada nos sítios rasos pela técnica de PCR convencional (Figura 5), e concordam com os estudos de outros autores (YAMABE et al., 2008), que relatam que a prevalência deste domínio aumenta em sítios com comprometimento periodontal. Diferente dos dados encontrados para PCR convencional e discordando também do estudo de Lepp et al. (2004), os dados por PCR quantitativo não apresentaram diferença estatisticamente significante para a prevalência de Archaea entre sítios rasos e com $\mathrm{PS} \geq 5 \mathrm{~mm}$.

A análise da literatura mostrou ser este o primeiro relato de detecção de Archaea no ambiente subgengival de indivíduos com saúde periodontal. No presente estudo, a prevalência de Archaea foi semelhante entre os indivíduos com saúde $(63,3 \%)$ e com doença periodontal (60\%) pelo PCR convencional (Tabela 3) e PCR quantitativo (86,7\% e 96,4\%, respectivamente) (Tabela 4). Estudos prévios relataram que Archaea não foi detectado em amostras de indivíduos periodontalmente saudáveis (LEPP et al., 2004; YAMABE et al., 2008; LI et al. 2009), analisando indivíduos dos Estados Unidos, Japão e China, respectivamente.

Aspectos metodológicos, como número de amostras analisadas por indivíduo, podem dificultar a comparação dos resultados entre os estudos. Embora Archaea tenha sido detectado em amostras subgengivais em mais da metade dos indivíduos dos grupos PA e SP no presente estudo, a análise por sítio revela que, em um mesmo indivíduo, poucos sítios albergavam representantes deste domínio por PCR convencional (Tabela 3). Por outro lado, devido à alta sensibilidade do PCR quantitativo, o domínio foi detectado na maioria dos sítios, em ambos os grupos (Tabela 4). Assim a baixa prevalência de Archaea por indivíduo e particularmente a ausência da detecção do domínio em indivíduos saudáveis em outros estudos poderiam ser explicadas pela análise de apenas um ou um limitado número de sítios por indivíduo e/ou pelo emprego de uma técnica de menor sensibilidade (LEPP et al., 2004; YAMABE et al.; 2008; VIANNA et al., 2008; LI et al., 2009).

Por outro lado, a discordância entre os estudos pode ser devida a diferenças na prevalência de Archaea entre diferentes populações. Diferenças na presença de microrganismos periodontopatogênicos foram relatadas em amostras de biofilme gengival de indivíduos com periodontite crônica de diferentes regiões geográficas (HAFFAJEE et 
al., 2004; HAFFAJEE et al., 2005). Da mesma maneira, as evidências apontam diferenças na prevalência de microrganismos metanogênicos entre populações. A análise do nível de metano no hálito permitiu mostrar que a proporção de metanogênicos entre a população adulta nos Estados Unidos e na Grã-Bretanha foi maior do que no Japão (MORII et al., 2003).

A presença de microrganismos do domínio Archaea foi associada à saúde no trato gastrointestinal, questionando a hipótese de que estes organismos estariam estritamente relacionados à doença. Scanlan et al. (2008) relataram que a prevalência de Archaea é equivalente no trato gastrointestinal de indivíduos saudáveis, com câncer colorretal, polipectomizados e com síndrome do intestino irritável, variando de 45 a 50\%. Por outro lado, estes organismos foram detectados em freqüências menores em doenças inflamatórias do intestino (doença de Crohn e colite ulcerativa, 30 e $24 \%$, respectivamente), sugerindo que a freqüência reduzida de Archaea metanogênicos poderia servir como um marcador biológico de alterações da diversidade microbiana no trato gastrointestinal humano.

Apesar da diversidade do domínio Archaea ser ampla em amostras ambientais, em superfícies humanas, incluindo a cavidade bucal, a diversidade de Archaea apresenta-se muito baixa, apesar desta análise ser restrita a um limitado número de estudos (LEPP et al., 2004; YAMABE et al., 2008; LI et al., 2009; VIANNA et al., 2009). No presente estudo foram detectados três filotipos do domínio Archaea, provenientes de gêneros diferentes, mas pertencentes ao mesmo reino, Euryarchaeota (WOESE et al., 1990): Methanobrevibacter oralis, Methanobacterium curvum/congolense e Methanosarcina mazeii, sendo M. oralis o mais prevalente.

Os estudos sobre a diversidade microbiana baseados em sequências $16 S$ rRNA geralmente consideram as espécies como unidades taxonômicas operacionais (OTUs), designadas como OTUs ou filotipos (PASTER et al., 2001; SCHLOSS; KEMP; ALLER, 2004; HANDELSMAN, 2005; ACHTMAN; WAGNER, 2008; ALLER; KEMP, 2008 FAVERI et al., 2008). Estas sequências possuem baixa resolução genética para identificar espécies, e métodos mais seguros, como a comparação de todos os genes ortólogos, seriam mais confiáveis (ACHTMAN; WAGNER, 2008). No entanto, atualmente, comparações do genoma completo para o acesso da diversidade não são ainda tão facilmente acessíveis e impediriam este tipo de estudo em grande número de amostras. Por outro lado, sequências 
de $16 S$ rRNA que apresentem similaridade $\leq 98,7 \%$ são geralmente obtidas de membros de espécies diferentes, pois grandes diferenças em $r R N A$ correlacionam-se com similaridade DNA-DNA $<70 \%$. No entanto, o oposto não é necessariamente verdadeiro e espécies distintas podem apresentar identidade em $16 S$ rRNAs $>98,7 \%$ (ATCHMAN; WAGNER, 2008), como foi observado no presente estudo para o filotipo M. curvum/congolense. Assim, no presente estudo foi empregado o termo filotipo, e não espécie, para designar aquelas sequências com similaridade $>99 \%$.

Os estudos que avaliaram a presença e diversidade de Archaea em amostras de biofilme subgengival (KULIK et al. 2001; LEPP et al., 2004; LI et al., 2009) ou de canais radiculares (VIANNA et al. 2006; VICKERMAN et al. 2007) também relataram predominantemente a detecção de $M$. oralis.

Os demais filotipos detectados no presente estudo não haviam ainda sido relatados de maneira conclusiva em humanos. Existe o relato na literatura de que um microrganismo com características fisiológicas e morfotintoriais relacionado à Methanosarcina sp. foi identificado em amostras de biofilme subgengival (ROBICHAUX; HOWELL; BOOPATHY, 2003b). No entanto, este dado deve ser interpretado com cautela visto ser resultado apenas de testes fenotípicos.

Não são conhecidos relatos na literatura de deteç̧ão de $M$. curvum/congolense no homem, sendo que estes organismos foram primeiramente detectados, no solo ao redor de uma fábrica de cervejas, onde os resíduos são descartados (SUN; DONG; ZHOU, não publicado*), e na casca de mandioca (CUZIN et al., 2001).

A origem do domínio Archaea na cavidade bucal pode ser discutida. Brusa, Ferrari e Canzi (1998), investigando a presença de Archaea metanogênicas em alimentos que não foram submetidos a processamento químico-físico, sugeriram que dificilmente os alimentos seriam a origem de Archaea que colonizam o aparelho digestivo, pois foram encontradas espécies distintas nos alimentos e no trato orogastrointestinal. Enquanto no trato gastrointestinal prevalecem as espécies Methanobrevibacter smithii e M. oralis, em alimentos foram detectados gêneros como Methanosarcina e Methanobacterium. Desta forma, a menor prevalência de M. mazeii ( 8 de 20 indivíduos) e M. curvum/congolense ( 9 de 20 indivíduos) na amostras bucais positivas para Archaea, quando comparadas à

*SUN, Z.; DONG, X.; ZHOU,Y. Phylogenetic research of a new species of methanogen. Nãopublicado. Genbank, AF275968, 11-Jun-2000. 
prevalência de M. oralis (100\%), associada à detecção dos primeiros em alimentos, sugerem que possivelmente estes organismos não fazem parte da microbiota residente da cavidade bucal, e a sua detecção tenha sido resultado da presença transitória, após ingestão de alimentos contaminados.

Esta hipótese poderia ser sugerida também pela comparação da porcentagem de clones identificados como M. oralis, M. curvum/congolense e M. mazeii (Figura 6) na análise da diversidade com a quantidade de cópias do gene $16 S$ rRNA de Archaea (dados não demonstrados) nas amostras obtidas dos indivíduos com periodontite agressiva e saúde periodontal. Por exemplo, nas amostras dos indivíduos 1, 4, 5 e 7 com periodontite agressiva foram detectados exclusivamente $M$. oralis e estas apresentaram o valor médio do número de cópias de $16 S \mathrm{SRNA}$ de Archaea de 9,1 $\pm 9,8 \times 10^{5}$ /amostra (variação 1,2 × $10^{5}$ a $2,3 \times 10^{6}$ ). Por outro lado, as amostras dos pacientes 2 e 10, que apresentavam predominantemente $M$. mazeii e $M$. curvum/congolense, respectivamente, os níveis de cópias de $16 S r R N A$ de Archaea/amostra foram 6,9 x $10^{3}$ e 5,6 x $10^{3}$, respectivamente. Nas amostras de indivíduos com saúde, esta possível relação não pode ser observada, pois em todas as amostras em que o estudo de diversidade foi feito, os valores do número de cópias de $16 S$ rRNA de Archaea foram baixos (variação 3,6 x $10^{2}$ a 2,7 x 10 ${ }^{3}$ ). Assim, os dados sugerem que apenas $M$. oralis seria capaz de atingir níveis mais elevados de Archaea nos sítios subgengivais, hipótese que deve ser confirmada pela análise quantitativa por espécie em maior número de amostras.

A baixa diversidade de Archaea observada nos sítios subgengivais poderia refletir que, ao contrário do domínio Bacteria, representantes de Archaea, com exceção de $M$. oralis, são pouco adaptados a este nicho em particular (LEPP et al. 2004), como em outros ambientes apresentando microbiota competidora (ALLER; KEMP, 2008). Assim, os dados sugerem que Archaea pode perceber e fazer uso do ambiente de uma forma mais restrita que Bacteria, apresentando uma menor flexibilidade fisiológica em ambientes não extremos (ALLER; KEMP, 2008), e tornando-se numericamente dominante apenas em ambientes extremos, devido à seleção.

O estudo de Archaea como parte da microbiota humana ainda é bastante novo. Contradizendo estudos prévios, pode-se sugerir que a simples presença destes organismos 
não parece estar associada ao desenvolvimento da periodontite agressiva generalizada. A pequena diversidade em $16 S r R N A$ observada entre as seqüências aqui detectadas, como evidenciado pela predominância de M. oralis, entre os Archaea, nas duas situações clínicas, suportam a hipótese de que esta espécie é residente nos sítios subgengivais, independente da condição periodontal. Portanto, para o entendimento da participação de Archaea no ecossistema subgengival torna-se fundamental a análise quantitativa deste domínio em relação ao domínio Bacteria em amostras obtidas de sítios subgengivais com diferentes condições periodontais.

Uma busca foi realizada na literatura com a finalidade de se escolher um iniciador adequado para PCR quantitativo (NADKARNI et al., 2002) e que também apresentasse sensibilidade e especificidade para os domínios envolvidos. Especialmente para o domínio Bacteria, é comumente relatada a presença de background nos ciclos finais (NADKARNI et al., 2004; EINEN; THORSETH; OVRE, 2008). O par de iniciadores descrito por Einen, Thorseth e Ovre (2008) foi escolhido, pois testes preliminares demonstraram que o número de amplicons nas amostras clínicas excedia cerca de 2 a 3 ordens de magnitude o valor do controle negativo, não gerando resultados falsos positivos.

O PCR quantitativo foi mais sensível que o convencional, como demonstrado na análise dos dados de prevalência empregando as duas técnicas. Estas diferenças na detecção por PCR convencional e quantitativo já foram relatadas na literatura (DWORKIN; GIVLER; VAN GELDER, 2002; DAGHER et al. 2004; HIERL et al., 2004; LUGERT; SCHETTLER; GROSS, 2006).

É importante ressaltar que os níveis e proporções de Archaea e Bacteria foram expressos pelo número de cópias do gene $16 \mathrm{~S} r R N A$ de cada domínio. Deve ser relatado, no entanto, que o número médio de operons do gene $16 S$ rRNA para Bacteria é de 4,06 enquanto este valor é de 1,77 para Archaea (valores obtidos em 12/2009 do banco de dados de RNA ribossômico para o número de cópias do operon $16 S \quad r R N A$, rrdnb) (KLAPPENBACH et al., 2001). Assim, se os valores fossem convertidos em números de células, estes valores deveriam ser divididos por 4 para Bacteria e por 1,8 para Archaea.

Os níveis e proporções de Archaea foram significantemente maiores no grupo com periodontite agressiva do que com periodonto saudável (Tabela 5 e Figura 10). Além disso, os níveis de Archaea foram maiores nos sítios com $\mathrm{PS} \leq 3 \mathrm{~mm}$ de indivíduos com 
periodontite agressiva generalizada do que de indivíduos periodontalmente saudáveis (Figura 11), embora estas diferenças não tenham sido estatisticamente significantes. Além disso, a freqüência de sítios rasos positivos para Archaea para o grupo com saúde periodontal e periodontite agressiva generalizada foi de 58,3\% e 72,5\%, respectivamente, também sem diferenças estatisticamente significantes (Figura 9). Na ecologia microbiana periodontal é muito significante o fato de sítios sem perda de inserção de indivíduos doentes albergarem periodontopatógenos mais frequentemente e em maior quantidade do que sítios de indivíduos saudáveis (RIVIERE et al., 1996; HAFFAJEE et al. 1999). Estes dados poderiam indicar que bolsas profundas de indivíduos doentes poderiam agir como reservatórios de disseminação do domínio Archaea para sítios saudáveis, o que poderia explicar a sua maior quantidade nos sítios rasos de indivíduos com doença do que nos de pacientes saudáveis. Por outro lado, estes dados poderiam indicar que os sítios saudáveis do grupo PA foram colonizados antes do início e progressão da doença.

As amostras de biofilme subgengival de indivíduos doentes apresentaram maior quantidade do domínio Bacteria do que as amostras de indivíduos periodontalmente saudáveis, assim como foi demonstrada uma associação positiva dos níveis de Bacteria com a profundidade de sondagem. Dados semelhantes foram relatados em estudos que avaliaram sítios saudáveis e doentes utilizando hibridação DNA-DNA por checkerboard (XIMENEZ-FYVIE et al., 2000, XIMENEZ-FYVIE et al., 2006; FAVERI et al., 2009).

Como diferentes quantidades de biofilme podem ser coletadas de sítios com e sem doença, credita-se maior relevância aos resultados de proporção do domínio Archaea em relação ao total de procariontes do que a análise de número de cópias/amostra. Estes dados revelaram que o percentual de cópias do gene $16 S$ rRNA de Archaea foi 4 vezes maior nas amostras de sítios de indivíduos com periodontite agressiva do que do grupo com saúde periodontal (Tabela 5). No entanto, a proporção de cópias de $16 S$ rRNA de Archaea em relação ao total das cópias de organismos procariontes não diferiu entre as amostras obtidas de sítios rasos ou profundos do grupo com periodontite agressiva, pois a quantidade de Bacteria também aumentou proporcionalmente com o aumento na profundidade de sondagem (Figura 12). As proporções de Archaea em relação ao total de procariontes aqui determinadas (Figura 5) foram muito menores do que as descritas por Lepp et al. (2004), para indivíduos com periodontite crônica. Estes autores relataram que os sítios com 
periodontite severa positivos para Archaea, apresentavam 18,5\% da microbiota composta por Archaea, mostrando ainda que a sua abundância aumentava com a severidade da doença. Por outro lado, Vianna et al (2008) demonstraram que metanogênicos representavam apenas $0,26 \%$ da microbiota em relação ao domínio Bacteria em indivíduos com periodontite crônica na Alemanha. As diferenças nos resultados poderiam ser devido a diferenças na prevalência de Archaea entre as populações, como relatado anteriormente, mas diferenças na metodologia podem também ter influenciado os dados. Além disso, diferenças na microbiota da periodontite crônica e agressiva poderiam ser responsáveis pelos resultados distintos entre os estudos.

Apesar de estudos sobre aspectos funcionais da diversidade microbiana de sítios subgengivais serem muito escassos (VIANNA et al., 2008), dados obtidos de outros ecossistemas podem ajudar a explicar o papel dos metanogênicos na cavidade bucal. Organismos capazes de fermentar polissacarídeos produzem ácidos orgânicos como acetato, propionato, butirato e formato, assim como $\mathrm{H}_{2}$ e $\mathrm{CO}_{2}$. Assim, o hidrogênio é um importante subproduto em ambientes anóxicos, promovendo um equilíbrio entre produtores e consumidores de $\mathrm{H}_{2}$ (DEPPENMEIER, 2002). $\mathrm{O}$ consumo de $\mathrm{H}_{2} \mathrm{e} \mathrm{CO}_{2}$ pelos organismos metanogênicos provavelmente favoreceria a proliferação de fermentadores (CONWAY DE MACARIO; MACARIO, 2008), enquanto altas concentrações de $\mathrm{H}_{2}$ iriam reduzir a eficiência da fermentação (CHASSARD et al., 2008). Enquanto isso, bactérias redutoras de sulfato competem com metanogênicos pelo $\mathrm{H}_{2}$, havendo a possibilidade de exclusão do nicho, apesar das duas populações coexistirem em níveis comparáveis de abundância no intestino (CONWAY DE MACARIO; MACARIO, 2008). Assim, foi demonstrado que no ambiente subgengival a proporção média de metanogênicos era 3,3 vezes maior em amostras negativas para bactérias redutoras de sulfato (representados por espécies de Desulfovibrio) do que nas amostras positivas, e 9 vezes maior em amostras com ausência de acetogênicos (representados por microrganismos não cultiváveis e possivelmente Treponema) do que nas amostras acetogênicos positivas (VIANNA et al., 2008). Esta sintrofia também pode explicar a abundância relativamente baixa do gênero Treponema em sítios subgengivais positivos para Archaea metanogênicos, devido a competição por $\mathrm{H}_{2}$ (LEPP et al., 2004). 
Além disso, a produção de outros subprodutos bacterianos presentes no biofilme dental, como sulfetos e nitritos, poderiam ser tóxicos para os metanogênicos, sob certas condições (PERSSON et al., 1990; SCHREIBER et al., 2010; MOHANAKRISHNAN et al., 2008). Vários periodontopatógenos produzem quantidades significantes de sulfeto de hidrogênio (PERSSON et al., 1990), sendo que $P$. gingivalis, $S$. anginosus e $F$. nucleatum são os maiores produtores destes por degradação dos compostos de cisteína (YOSHIDA et al., 2009). Dados sobre a microbiota da periodontite agressiva generalizada (FAVERI et al., 2008; FAVERI et al., 2009) demonstraram que a proporção de Fusobacterium nucleatum ssp. polymorphum e $P$. gingivalis está aumentada em periodontite agressiva generalizada em comparação com amostras de periodontite crônica, enquanto a proporção de $A$. naeslundii 1, um organismo fermentador, é maior na periodontite crônica. Assim, é possível que existam também diferenças na quantidade de metanogênicas em sítios com perda periodontal em pacientes com periodontite agressiva ou crônica. Apesar de conclusões definitivas não poderem ser delineadas antes da realização de estudos funcionais, a proporção de sítios positivos para Archaea poderia ser correlacionada negativamente com os níveis dos competidores ou antagonistas dos metanogênicos e positivamente com os níveis de fermentadores.

A maior proporção de metanogênicos em indivíduos com periodontite agressiva do que nos saudáveis poderia indicar alteração no ecossistema oral dos primeiros, pois embora Archaea não sejam possivelmente produtores de toxinas e enzimas com potencial para destruição e/ou invasão tecidual, estes poderiam promover condições para a proliferação de outros microganismos (CONWAY DE MACARIO; MACARIO, 2008). Apesar da baixa proporção e diversidade de Archaea nos sítios subgengivais, estes foram claramente associados à periodontite agressiva, embora possam ser detectados em indivíduos com periodonto saudável. Os dados sugerem que $M$. oralis poderia ser considerado membro da microbiota residente que encontra maiores condições de proliferação em alguns indíviduos. Periodontite não é uma doença atribuída a um único agente etiológico, e os diferentes grupos microbianos mesmo que em baixas proporções, como os capazes de utilizar $\mathrm{H}_{2}$ como Archaea, devem contribuir alterando o ecossistema em direção a uma microbiota associada à doença. 


\section{CONCLUSÃO}

A análise da prevalência, diversidade, quantidade e proporção do domínio Archaea em amostras de biofilme subgengival de indivíduos com periodontite agressiva e saúde periodontal permitiu demonstrar que:

- Archaea é encontrado em alta freqüência em indivíduos com periodontite agressiva generalizada e com periodonto saudável.

- A diversidade de Archaea é baixa em sítios subgengivais, e Methanobrevibacter oralis é o filotipo predominante do domínio Archaea no biofilme subgengival.

- O domínio Archaea é detectado em maior quantidade e proporção em sítios subgengivais de indivíduos com periodontite agressiva do que com periodonto saudável.

Assim, baseados na metodologia empregada, podemos concluir que:

M. oralis pode ser considerado membro da microbiota residente normal de sítios subgengivais do homem.

Em indivíduos com periodontite agressiva generalizada, a alteração no ecossistema subgengival em relação à saúde periodontal inclui o aumento do número e proporções de Archaea. 


\section{REFERÊNCIAS ${ }^{*}$}

ACTHMAN, M.; WAGNER, M. Microbial diversity and the genetic nature of microbial species. Nat. Rev. Microbiol., v. 6, n. 6, p. 431-440, 2008.

AINAMO, J.; BAY, I. Problems and proposals for recording gingivitis and plaque. Int. Dent. J., v. 25, p. 229-235, 1975.

ALLER, J. Y.; KEMP, P. F. Are Archaea unherently less diverse than Bacteria in the same environment? FEMS Microbiol. Ecol., v. 65, p. 74-87, 2008.

ARAÚJO, M. W.; HOVEY, K. M.; BENEDEK, J. R.; GROSSI, S. G.; DORN, J.; WACTAWSKI-WENDE, J.; GENCO, R. J.; TREVISAN, M. Reproducibility of probing depth measurement using a constant-force electronic probe: analysis of inter- and intraexaminer variability. J. Periodontol., v. 74, n. 12, p. 1736-1740, 2003.

ARMITAGE, G. C. Development of a classification system for periodontal diseases and conditions. Ann. Periodontol., v. 4, p. 1-6, 1999.

BELAY, N.; JOHNSON, R.; RAJAGOPAL, B. S.; CONWAY DE MACARIO, E.; DANIELS, L. Methanogenic bacteria from human dental plaque. Appl. Environ. Microbiol., v. 54, p. 600-603, 1988.

BELAY, N.; MUKHOPADHYAY, B.; CONWAY DE MACARIO, E.; GALASK, R.; DANIELS, L. Methanogenic bacteria in human vaginal samples. J. Clin. Microbiol., v. 28, p. 1666-1668,1990.

BRUSA, T.; FERRARI, F.; CANZI, E. Methanogenic bacteria: presence in foodstuffs. J. Basic Microbiol., v. 38, n. 2, p. 79-84, 1998.

CAVICCHIOLI, R.; CURMI, P.M.; SAUNDERS, N.; THOMAS, T. Pathogenic archaea: do they exist? Bioessays, v. 25, p. 1119-1128, 2003.

CHASSARD, C., SCOTT, K. P.; MARQUET, P.; MARTIN, J. C.; DEL'HOMME, C.; DAPOIGNY, M.; FLINT, H. J.; BERNALIER-DONADILLE, A. Assessment of metabolic diversity within the intestinal microbiota from healthy humans using combined molecular and cultural approaches. FEMS Microbiol. Ecol., v. 66, p. 496-504, 2008.

CONWAY DE MACARIO, E., MACARIO, A. J. L. Methanogenic archaea in health and disease: A novel paradigm of microbial pathogenesis. Int. J. Med. Microbiol., 2008.

COSTERTON, J. W.; STEWART, P. S.; GREENBERG, E. P. Bacterial biofilms: a common cause of persistent infections. Science, v. 21; p. 1318-1322, 1999.

*De acordo com:

ASSOCIAÇÃO BRASILEIRA DE NORMAS TÉCNICAS. NBR 6023: Informação e documentação:

referências: elaboração. Rio de Janeiro, 2002. 
CUZIN, N.; OUATTARA, A. S.; LABAT, M.; GARCIA, J. L. Methanobacterium congolense sp. nov., from a methanogenic fermentation of cassava peel. Int. J. Syst. Evol. Microbiol., v. 51, p. 489-493, 2001.

DAGHER, H.; DONNINGER, H.; HUTCHINSON, P.; GHILDYAL, R.; BARDIN, P. Rhinovirus detection: comparison of real-time and Conventional PCR. J. Virol. Methods, v. 117, p. 113-121, 2002.

DELONG, E. F. Archaea means in coastal marine environments. Proc. Natl. Acad. Sci. USA., v. 89, p. 5685-5689, 1992.

DEWHIRST, F. E.; TAMER, M. A.; ERICSON, R. E.; LAU, C. N.; LEVANOS, V. A.; BOCHES, S. K.; GALVIN, J. L.; PASTER, B. J. The diversity of periodontal spirochetes by 16S rRNA analysis. Oral Microbiol. Immunol., v. 15, n. 3, p. 196-200, 2000.

DEPPENMEIER, U. Redox-driven proton translocation in methanogenic Archaea. Cell. Mol. Life Sci., v. 59, p. 1513-1533, 2002.

DRIDI, B.; HENRY, M.; EL KHÉCHINE, A.; RAOULT, D.; DRANCOURT, M. High prevalence of Methanobrevibacter smithii and Methanosphaera stadtmanae detected in the human git using an improved DNA detection protocol. PLoS One, v. 17, p. e7063, 2009.

DWORKIN, L. L.; GIVLER, T. M.; VAN GELDER, R. N. Real-time quantitative polymerase chain reaction diagnosis of infectious posterior uveitis. Arch. Ophthalmol., v. 120, p. 1534-1539, 2002.

EINEN, J.; THORSETH, I.H.; OVRE, L. Enumeration of Archaea and Bacteria in seafloor basalt using real-timequantitative PCR and fluorescence microscopy. FEMS Microbiol. Lett., v. 282, p. 182-187, 2008.

ECKBURG, P. B.; LEPP, P. W.; RELMAN, D. A. Archaea and their potencial role in human disease. Infect. Immun., v. 71, p. 591-596, 2003.

FAVERI, M.; MAYER, M. P. A.; FERES, M.; FIGUEIREDO, L. C.; DEWHIRST, F. E.; PASTER, B. J. Microbiological diversity of generalized aggressive periodontitis by $16 \mathrm{~S}$ rRNA clonal analysis. Oral Microbiol. Imunol., v. 22, p. 1-7, 2008.

FAVERI, M.; FIGUEIREDO, L. C.; DUARTE, P. M.; MESTNIK, M. J.; MAYER, M. P. A.; FERES, M. Microbiological profile of untreated subjects with localized aggressive periodontitis. J. Clin. Periodontol., v. 36, p. 739-749, 2009.

FERRARI, A.; BRUSA, T.; RUTILL, A.; CANZI, E.; BIAVATI, B. Isolation and characterization of Methanobrevibacter oralis sp. nov. Curr. Microbiol., v. 29, p. 7-12, 1994. 
GOOD, I. L. The population frequencies of species and estimation of population parameters. Biometrica, v. 40, p. 237-264, 1953.

HAFFAJEE, A. D.; BOGREN, A.; HASTURK, H.; FERES, M.; LOPEZ, N. J.; SOCRANSKY, S. S. Subgingival microbiota of chronic periodontitis subjects from different geographic locations. J. Clin. Periodontol., v. 31, p. 996-1002, 2004.

HAFFAJEE, A.D.; JAPLIT, M.; BOGREN, A.; KENT, R. L. JR.; GOODSON, J. M.; SOCRANSKY, S. S. Differences in the subgingival microbiota of Swedish and USA subjects who were periodontally healthy or exhibited minimal periodontal disease. J. Clin. Periodontol. v. 32, p. 33-39, 2005.

HAFFAJEE, A. D.; SOCRANSKY, S. S. Microbial etiological agents of destructive periodontal diseases. Periodontol. 2000, v. 5, p. 78-111, 1994.

HAMLET, S. M.; CULLINAN, M. P.; WESTERMAN, B.; LINDEMAN, M.; BIRD, P. S.; PALMER, J.; SEYMOUR, G. J. Distribution of Actinobacillus actinomycetemcomitans, Porphyromonas gingivalis and Prevotella intermedia in an Australian population. J. Clin. Periodontol., v. 28, n. 12, p. 1163-1171, 2001.

HIERL, T.; REISCHL, U.; LANG, P.; HEBART, H.; STARK, M.; KYME, P.; AUTENRIETH, I. B. Preliminary evaluation of one conventional nested and two real-time PCR assays for the detection of Toxoplasma gindii in immunocompromised patients. $\mathbf{J}$. Med. Microbiol., v. 53, p. 629-632, 2004.

HIGUCHI, M. D. E. L.; KAWAKAMI, J.; IKEGAMI, R.; CLEMENTINO, M. B.; KAWAMOTO, F. M.; REIS, M. M.; BOCCHI, E. Do Archaea and bacteria co-infection have a role in the pathogenesis of chronic chagasic cardiopathy? Mem. Inst. Oswaldo Cruz, v. 104, p. 199-207, 2009.

JUKES, T. H.; CANTOR, C. R. Evolution of protein molecules. In: Munro H. N. (Ed.). Mammalian protein metabolism. New York: Academic Press, Inc., 1969. p. 21-132.

KAMMA, J. J.; NAKOU, M.; GMUR, R.; BAEHNI, P. C. Microbiological profile of early onset/aggressive periodontitis patients. Oral. Microbiol. Immunol., v. 19, n. 5, p. 314$321,2004$.

KAZOR, C. E.; MITCHELL, A. M.; LEE, A. M.; STOKES, L. N.; LOESCHE, W. J.; DEWHIRST, F. E.; PASTER, B. J. Diversity of bacterial populations on the tongue dorsa of patients with halitosis and healthy patients. J. Clin. Microbiol., v. 41, n. 2, p. 558-563, 2003.

KEMP, P. F., ALLER, J. Y. Bacterial diversity in aquatic and other environments: what 16S rRNA library can tell us. FEMS Microbiol. Ecol., v. 47, p. 161-177, 2004. 
KOLENBRANDER, P. E.; PALMER, R. J. JR.; RICKARD, A. H.; JAKUBOVICS, N. S.; CHALMERS, N. I.; DIAZ, P. I. Bacterial interactions and successions during plaque development. Periodontol. 2000., v. 42, p. 47-79, 2006.

KOLENBRANDER, P. E.; EGLAND, P. G.; DIAZ, P. I.; PALMER, R. J. JR.Genomegenome interactions: bacterial communities in initial dental plaque. Trends Microbiol., v. 13, p. 11-15, 2005.

KULIK, E. M.; SANDMEIER, H.; HINNI, K.; MEYER, J. Identification of archaeal rDNA from subgingival dental plaque by PCR amplification and sequence analysis. FEMS Microbiol. Lett., v. 196, p. 129-133, 2001.

KLAPPENBACH, J. A.; SAXMAN, P. R.; COLE, J. R.; SCHMIDT, T. M. rndb: the Ribossomal RNA Operon copy number database. Nucleic Acids Res., v. 29, p. 181-184, 2001.

LEPP, P. W.; BRING, M. M.; OUVERNEY, C. C.; PALM, C.; ARMITAGE G. C.; RELMAN D. A. Methanogenic Archaea and human periodontal disease. Proc. Natl. Acad. Sci. USA, v. 16, p. 6176-6181, 2004.

LI, C. L.; LIU, D. L.; JIANG, Y. T.; ZHOU, Y. B.; ZHANG, M. Z.; JIANG, W.; LIU, B.; LIANG J. P. Prevalence and molecular diversity of Archaea in subgingival pockets of periodontitis patients. Oral Microbiol. Immunol., v. 24, p. 343-346, 2009.

LÖE, H.; THEILADE, E.; JENSEN, S. B. Experimental gingivitis in man. J. Periodontol., v. 36, p. $177-187,1965$.

LOUIS, B. G.; FITT, P. S. Isolation and properties of highly purified Halobacterium cutirubrum deoxyribonucleic acid-dependent ribonucleic acid polymerase. Biochem. J., v. 127, p. 69-80, 1972.

LÖSEKANN, T.; KNITTEL, K.; NADALIG, T.; FUCHS, B.; NIEMANN, H.; BOETIUS, A.; AMANN, R. Diversity and abundance of aerobic and anaerobic methane oxidizers at the Haakon Mosby Mud Volcano, Barents Sea. Appl. Environ. Microbiol., v. 73, p. 33483362, 2007.

LUGERT, R.; SCHETTLER, C.; GROSS, U. Comparison of different protocols for DNA preparation and PCR for the detection of fungal pathogens in vitro. Mycoses, v. 49, p. 298304, 2006.

MADIGAN, M. T.; MARTINKO, J. M.; PARKER, J. Evolução e sistemática microbianas. In: MADIGAN, M. T.; MARTINKO, J. M.; PARKER, J. (Ed.) Microbiologia de Brock. São Paulo: Prentice Hall, 2004. p. 302-330. 
MARSH, P. D. Microbial ecology of dental plaque and its significance in health and disease. Adv. Dent. Res., v. 8, p. 263-271, 1994.

MCCONNELL, D. J.; SEARCY, D. G.; SUTCLIFFE, J. G. A restriction enzyme Tha I from the thermophilic mycoplasma Thermoplasma acidophilum. Nucleic Acids Res., v. 5, p. 1729-39, 1978.

MCKAY, L. F.; BRYDON, W. G.; EASTWOOD, M. A.; HOUSLEY, E. The influence of peripheral vascular disease on methanogenesis in man. Atherosclerosis, v. 47, p. 77-81, 1983.

MIHAJLOVSKI, A.; ALRIC, M.; BRUGERE, J-F. A putative new order of methanogenic Archaea inhabiting the human gut, as revealed by molecular analyses of the mcrA gene. Res. Microbiol., v. 159, p. 516-521, 2008.

MILLER, T. L.; WOLIN, M. J.; CONWAY DE MACARIO, E.; MACARIO, A. J. L. Isolation of Methanobrevibacter smithii from human feces. Appl. Environ. Microbiolol., v. 43, p. 227-232, 1982.

MOHANAKRISHNAN, J.; GUTIERREZ, O.; MEYER, R.L.; YUAN, Z. Nitrite effectively inhibits sulfide and methane production in a laboratory scale sewer reactor. Water Res., v. 42, p. 3961-3971, 2008.

MORII, H.; ODA, K.; SUENAG, Y.; NAKAMURA, T. Low methane concentration in the breath of Japanese. J. UOEH, v. 25, p. 397-407, 2003.

Mullally, B. H.; DACE, B.; SHElBURnE, C. E.; WOlF, L. F.; COUlTER, W. A. Prevalence of periodontal pathogens in localized and generalized forms of early onset periodontitis. J. Periodontol. Res., v. 35, n. 4, p. 232-241, 2000.

NADKARNI, M. A; MARTIN, F. E.; JACQUES, N. A.; HUNTER, N. Determination of bacterial load by real time PCR using a broad-range (universal) probe and primers set. Microbiol., v. 148, p. 257-266, 2002.

NEWMAN, M. G.; SOCRANSKY, S. S. Predominante cultivable microbiota in periodontosis. J. Periodont. Res., v. 12, p. 120-128, 1977.

NEWMAN, M. G.; SOCRANSKY, S. S.; SAVITT, E. D.; PROPAS, D. A.; CRAWFORD, A. Studies of the microbiology of periodontosis. J. Periodontol. v. 47, p. 373-9, 1976.

OLSEN, G. J.; LANE, D. J.; GIOVANNONI, S. J.; PACE, N. R. Microbial ecology and evolution: a ribosomal RNA approach. Ann. Rev. Microbiol., v. 40, p. 337-365, 1986.

OVREAS, L.; TORSVIK, V. Microbial diversity and community structure in two different agricultural soil communities. Microb. Ecol., v. 36, p. 303-315, 1998. 
PAGE, R. C.; OFFENBACHER, S.; SCHROEDER, H. E.; SEYMOUR, G. J.; KORNMAN, K. S. Advances in the pathogenesis of periodontitis: summary of developments, clinical implications and future directions. Periodontol. 2000, v. 14, p. 216248, 1997.

PASTER, B. J.; BOCHES, S. K.; GALVIN, J. L.; ERICSON, R. E.; LAU, C. N.; LEVANOS, V. A.; SAHASRABUDHE, A.; DEWHIRST, F. E. Bacterial diversity in human subgingival plaque. J. Bacteriol., v. 183, n. 12, p. 3770-3783, 2001.

PERSSON, S.; EDLUND, M. B.; CLAESSON, R.; CARLSSON, J. The formation of hydrogen sulfide and methyl mercaptan by oral bacteria. Oral Microbiol. Immunol., v. 5, p. 195-201, 1990.

PELED, Y.; WEINBERG, D.; HALLAK, A.; GILAT, T. Factors affecting methane production in humans. Gastrointestinal diseases and alterations of colonic flora. Dig. Dis. Sci., v. 32, p. 267-271, 1987.

PIQUÉ, J. M.; PALlARÉS, M.; CUSÓ, E.; VILAR-BONET, J., GASSULL, M. A. Methane production and colon câncer. Gastroenterology, v. 87, 601-605, 1984.

RIVIERE, G. R.; SMITH, K. S.; TZAGAROULAKI, E.; KAY, S. L.; ZHU, X.; DEROUEN, T. A.; ADAMS, D. F. Periodontal status and detection frequency of bacteria at sites of periodontal health and gingivitis. J. Periodontol., v. 67, p. 109-115, 1996.

ROBICHAUX, M.; HOWELL, M.; BOOPATHY, R. Methanogenic activity in human periodontal pocket. Curr. Microbiol., v. 46, n. 1, p. 53-58, 2003 a.

ROBICHAUX, M.; HOWELL, M.; BOOPATHY, R. Growth and activities of sulfatereducing and methanogenic bacteria in human oral cavity. Curr. Microbiol., v. 47, p. 12$16,2003 b$.

RUTILI, A.; CANZI, E.; BRUSA, T.; FERRARI, A. Intestinal methanogenic bacteria in children of different ages. New Microbiol., v. 19, p. 227-243, 1996.

SAENGKERDSUB, S.; ANDERSON, R. C.; WILKINSON, H. H.; KIM, W. K.; NISBET, D. J.; RICKE, S. C. Identification and quantification of methanogenic Archaea in adult chicken ceca. Appl. Environ. Microbiol., v. 73, p. 353-356, 2007.

SANDERS, C. C.; SANDERS, W. E. JR.; GOERING, R. V.; WERNER, V. Selection of multiple antibiotic resistance by quinolones, beta-lactams, and aminoglycosides with special reference to cross-resistance between unrelated drug classes. Antimicrob. Agents Chemother., v. 26, p. 797-801, 1984.

SAKAMOTO, M.; UMEDA, M.; BENNO, Y. Molecular analysis of human oral microbiota. J. Periodontal. Res., v. 40, p. 277-85, 2005. 
SCANLAN, P. D.; SHANAHAN, F.; MARCHESI, J. R. Human methanogen diversity and incidence in healthy and disease colonic groups using mcrA gene analysis. BMC Microbiol., v. 8, n. 79, 2008.

SCHLOSS, P. D.; HANDELSMAN, J. Introducing DOTUR, a computer program for defining operational taxonomic units and estimating species richness. Appl. Environ. Microbiol., v. 71, p. 1501-1506, 2005.

SCHREIBER, F.; STIEF, P.; GIESEKE, A; HEISTERKAMP, I. M.; VERSTRAETE, W.; DE BEER, D.; STOODLEY, P. Denitrification in human dental plaque. BMC Biol., v. 8, n. 24, 2010.

SKILLMAN, L. C.; EVANS, P. N.; STROMPL, C; JOBLIN, K. N. 16S rDNA directed PCR primers and detection of methanogens in the bovine rumen. Lett. Appl. Microbiol., v. 42, p. 22-228, 2006.

SOCRANSKY, S. S.; HAFFAJEE, A. D. Implications of periodontal microbiology for the treatment of periodontal infections. J. Clin. Periodontol., v. 18, p. 688-93, 1994.

SOCRANSKY, S. S.; HAFFAJEE, A. D. Dental biofilms: dificult therapeutic targets. Periodontol. 2000., v. 28, p. 12-55, 2002.

SOCRANSKY, S. S.; HAFFAJEE, A. D. Periodontal microbial ecology. Periodontol. 2000., v. 38, p. 135-187, 2005.

SOCRANSKY, S. S.; HAFFAJEE, A. D.; CUGINI, M. A.; SMITH, C.; KENT JR., R.L. Microbial complexes in subgingival plaque. J. Clin. Periodontol., v. 25, p. 134-44, 1998.

SIQUEIRA, J. F. JR.; RÔÇAS, I. N.; BAUMGARTNER, J. C.; XIA, T. Searching for Archaea in infections of endodontic origin. J. Endod., v. 31, p. 719-721, 2005.

SLOTS, J. The predominant cultivable organisms in juvenile periodontitis. Scand. J. Dent. Res., v. 84, p. 1-10, 1976.

VIANNA, M. E.; CONRADS, C.; GOMES, B. P. F. A.; HORTZ H. P. Identification and quantification of Archaea involved in primary endodontic infections. J. Clin. Microbiol., v. 44, n. 4; p. 1274-1282, 2006.

VIANNA, M. E.; HOLTGRAEWE, S.; SEYFARTH, I.; CONRADS, C.; HORTZ, H. P. Quantitative Analysis of Three Hydrogenotrophic Microbial Groups, Methanogenic Archaea, Sulfate-Reducing Bacteria, and Acetogenic Bacteria, within Plaque Biofilms Associated with Human Periodontal Disease. J. Bacteriol., v. 190, p. 3779-3785, 2008.

VIANNA, M. E.; CONRADS, C.; GOMES, B. P. F. A.; HORTZ H. P. T-RFLP-based $m c r A$ gene analysis of methanogenic archaea in association with oral infections and 
evidence of a novel Methanobrevibacter phylotype. Oral Microbiol. Immunol., v. 24, p. 417-422, 2009.

VICKERMAN, M. M.; BROSSARD, K. A.; FUNK, D. B.; JESIONOWSKI, A. M.; GILL, S. R. Phylogenetic analysis of bacterial and archaeal species in symptomatic and asymptomatic endodontic infections. J. Med. Microbiol., v. 56, p. 110-118, 2007.

WEAVER, G. A.; KRAUSE, J. A.; MILLER, T. L.; WOLIN, M. J. Incidence of methanogenic bacteria in sigmoidoscopy population: an association of methanogenic bacteria and diverticulosis. Gut, v. 27, p. 698-704, 1986.

WOESE, C. R; KANDLER, O.; WHEELIS, M. L. Towards a natural system of organisms: proposal for the domains Archaea, Bacteria, and Eucarya. Proc. Natl. Acad. Sci. USA., v. 87, n. 12, p. 4576-4579, 1990.

WRIGHT, A. D.; WILlIAMS, A. J.; WINDER, B.; CHRISTOPHERSEN, C. T.; RODGERS, S. L.; SMITH, K. D. Molecular diversity of rumen methanogens from sheep in Western Australia. Appl. Environ. Microbiol., v. 70, p. 1263-1270, 2004.

XIMENEZ-FYVIE, L. A.; HAFFAJEE, A. D.; SOCRANSKY, S. S. Comparison of the microbiota of supra- and subgingival plaque in health and periodontitis. J. Clin. Periodontol., v. 27, n. 3, p. 648-657, 2000.

XIMENEZ-FYVIE, L. A.; ALMAGUER-FLORES, A.; JACOBO-SOTO, V.; LARACORDOBA, M.; MORENO-BORJAS, J. Y.; ALCANTARA-MARURI, E. Subgingival microbiota of periodontally untreated Mexican subjects with generalized aggressive periodontitis. J. Clin. Periodontol., v. 33, n. 12, p. 869-877, 2006.

YAMABE, K.; MAEDA, H; KOKEGUCHI, S.; TANIMOTO, I.; SONOI, N.; ASACAWA, S.; TAKASHIBA, S. Distribution of Archaea in Japanese patients with periodontitis and humoral immune response to the components. FEMS Microbiol. Lett., v. 287, p. 69-75, 2008.

YOSHIDA, A.; YOSHIMURA, M.; OHARA, N.; YOSHIMURA, S.; NAGASHIMA, S.; TAKEHARA, T.; Nakayama, K. Hydrogen sulfide production from cysteine and homocysteine by periodontal and oral Bacteria. J. Periodontol., v. 80, p. 1845-1851, 2008. 


\begin{abstract}
ANEXOA
TERMO DE CONSENTIMENTO LIVRE E ESCLARECIDO

C.E.P. 8.7. - ICruvisi?

Beotrici rivi Os 102106

Universidade de São Paulo

Instituto de Ciências Biomédicas

Ax ............

TERMO DE CONSENTIMENTO LIVRE E ESCLARECIDO DO PACIENTE

ESTUDO: Identificação de possiveis organismos associados à periodontite agressiva por análise clonal de 16SrRNA

Vocé está sendo convidado(a) a participar do projeto de pesquisa acima citado. O documento abaixo contém todas as informações necessárias sobre a pesquisa que estamos fazendo. Sua colaboração neste estudo será de muita importância para nós, mas se desistir a qualquer momento, isso não causará nenhum prejuizo a você.
\end{abstract}

Eu, ( inserir o nome, profissão, residente e domiciliado na portador da Cédula de identidade, RG , e inscrito no CPF/MF nascido(a) em _______ _ abaixo assinado(a), concordo de livre e espontânea vontade em participar como voluntário(a) do estudo "Identificação de possíveis organismos associados à periodontite agressiva por análise clonal de 16SrRNA". Declaro que obtive todas as informações necessárias, bem como todos os eventuais esclarecimentos quanto às dúvidas por mim apresentadas.

Estou ciente que:

I) O estudo se faz necessário para que se possam descobrir as possiveis causas da doença denominada "Doença periodontal agressiva" que pretende estudar o perfil de bactérias presentes na doença periodontal agressiva e identificar novas bactérias (germes) que possam estar associadas a doença. A doença periodontal agressiva é uma inflamação das gengivas e pode levar até à perda dos dentes;

II) Serão feitas coletas de placa dentária (sujeira dos dentes) presente em três diferentes dentes, sendo realizadas no mesmo dia;

III) Essa coleta serão feitas apenas para este estudo e em nada influenciará o tratamento; não vai me curar; não vai me causar nenhum problema, exceto o pequeno incômodo momento da coleta (introdução da cureta entre o espaço existente entre o dente e a gengiva);

IV) Todos os voluntários receberão o tratamento periodontal gratuitamente. O tratamento utilizado será de raspagem das superfícies dos dentes: coroa e raiz e o uso da associação de antibióticos (Amoxacilina $500 \mathrm{mg} 3 \mathrm{x} /$ dia durante 14 dias e Metronidazole $400 \mathrm{mg} 3 \mathrm{x} /$ dia durante 14 dias) utilizados no tratamento das doenças periodontais agressivas que irá ajudar na eliminação dos microrganismos (germes) 
presentes na placa dentária causadora da doença nas gengivas. Todos esses procedimentos são simples e não apresentam riscos para o paciente.

V) Tenho a liberdade de desistir ou de interromper a colaboração neste estudo no momento em que desejar, sem necessidade de qualquer explicação;

VI) A desistência não causará nenhum prejuizo à minha saúde ou bem estar físico. Não virá interferir no atendimento ou tratamento odontológico;

VII) Os resultados obtidos durante este ensaio serão mantidos em sigilo, mas concordo que sejam divulgados em publicações cientificas, desde que meus dados pessoais não sejam mencionados;

VIII) Caso eu desejar, poderei pessoalmente tomar conhecimento dos resultados, ao final desta pesquisa

( ) Desejo conhecer os resultados desta pesquisa.

( ) Não desejo conhecer os resultados desta pesquisa.

São Paulo, de de 2001

( ) Paciente / ( ) Responsável

Testemunha 1 :

Nome / RG / Telefone

Testemunha 2 :

Nome / RG / Telefone

Responsável pelo Frọ̣er:

Dr. Marcelo de Faveri, Periodontista, CRO-PR: 15.431

Dúvidas: Marcelo de Faveri

Rua Piracema, n 71 apto 71, Santa Terezinha, São Paulo

Tel: $8456-4521$

Dúvidas e reclamações

Secretaria da Comissão de Ética em Pesquisa com Seres Humanos - ICB/USP -Fone 3091.7733 